\title{
Structure-Based Design of Selective Fat Mass and Obesity Associated Protein (FTO) Inhibitors
}

Shifali Shishodia, Marina Demetriades, Dong Zhang, Nok Yin Tam, Pratheesh Maheswaran, Caitlin Clunie-O'Connor, Anthony Tumber, Ivanhoe K. H. Leung, Yi Min Ng, Thomas M. Leissing, Afaf H. El-Sagheer, Eidarus Salah, Tom Brown, Wei Shen Aik,* Michael A. McDonough,* and Christopher J. Schofield*

Cite This: J. Med. Chem. 2021, 64, 16609-16625

Read Online

山ll Metrics \& More

Article Recommendations

Supporting Information

ABSTRACT: FTO catalyzes the $\mathrm{Fe}(\mathrm{II})$ and 2-oxoglutarate (2OG)-dependent modification of nucleic acids, including the demethylation of $N^{6}$-methyladenosine $\left(\mathrm{m}^{6} \mathrm{~A}\right)$ in mRNA. FTO is a proposed target for anti-cancer therapy. Using information from crystal structures of FTO in complex with 2OG and substrate mimics, we designed and synthesized two series of FTO inhibitors, which were characterized by turnover and binding assays, and by X-ray crystallography with FTO and the related bacterial enzyme AlkB. A potent inhibitor employing binding interactions spanning the FTO $20 \mathrm{OG}$ and substrate binding sites was identified. Selectivity over other clinically targeted 2OG oxygenases was demonstrated, including with respect to the hypoxia-inducible factor prolyl and asparaginyl hydroxylases (PHD2 and FIH) and selected JmjC histone demethylases (KDMs). The results illustrate how structure-based design can enable the identification of potent and selective $2 \mathrm{OG}$ oxygenase inhibitors and will be useful for the development of FTO inhibitors for use in vivo.

\section{INTRODUCTION}

The fat mass and obesity associated protein (FTO) is an $\mathrm{Fe}(\mathrm{II})$ and 2-oxoglutarate (2OG)-dependent oxygenase that catalyzes the oxidation of $\mathrm{N}$-methyl groups in nucleic acids, and, in particular, of $N^{6}$-methyladenosine $\left(\mathrm{m}^{6} \mathrm{~A}\right)$ in RNA. ${ }^{1-3}$ FTO is a potential medicinal chemistry target due to its roles in obesity and cancer. Single nucleotide polymorphisms in an intron of the fto gene were reported to be associated with body weight and type II diabetes in genome-wide association studies. ${ }^{4,5}$ More recent studies have reported roles for FTO in $\mathrm{m}^{6} \mathrm{~A}$ regulation and cancers, including acute myeloid leukemia and glioblastoma. ${ }^{6-11}$ Precisely how RNA oxidation by FTO is linked to disease is uncertain. There is thus an unmet need to develop small-molecule probes to complement genetic studies and explore its potential as a therapeutic target.

FTO is one of $60-70$ human $20 \mathrm{G}$ oxygenases, some of which are medicinal chemistry targets, for example, the hypoxia-inducible factor prolyl hydroxylases (PHD 1-3) and selected JmjC $N^{\varepsilon}$-methyllysine histone demethylases (KDMs). ${ }^{12,13}$ PHD inhibitors are approved for the treatment of anemia in chronic kidney disease, though there have been concerns regarding their safety. ${ }^{14}$ Human nucleic acid oxygenases (NAOXs), including FTO, are a substantial subset of $2 \mathrm{OG}$ oxygenases (>10 enzymes). NAOXs include eight AlkB homologues (ALKBH 1-8), some of which are involved in DNA damage repair (e.g., ALKBH2) and RNA oxidation (e.g., FTO and ALKBH5) and the Ten Eleven Translocation enzymes (TET1-3), which catalyze sequential oxidations of the methyl group of 5-methylcytosine. ${ }^{15,16}$ FTO catalyzes hydroxylation which can lead to demethylation of $N$-methyl groups on single-stranded RNA and DNA substrates (Figure 1A), including $\mathrm{N}^{3}$-methylthymidine $\left(\mathrm{m}^{3} \mathrm{~T}\right), \mathrm{N}^{3}$-methyluridine $\left(\mathrm{m}^{3} \mathrm{U}\right), \mathrm{m}^{6} \mathrm{~A}$, and $\mathrm{N}^{6}, 2^{\prime} \mathrm{O}$-dimethyladenosine $\left(\mathrm{m}^{6} \mathrm{Am}\right) .{ }^{1-3,17}$ The lifetime of the nascent $\mathrm{N}$-hydroxymethylated products/ intermediates varies depending on the nucleobase undergoing oxidation, leading to the proposal that in some circumstances they may be biologically relevant. ${ }^{17-19}$

There are some reports of FTO inhibition, including by known inhibitors of $2 \mathrm{OG}$ oxygenases, such as PHD inhibitors (Figure S1). ${ }^{6,7,20-26}$ We have reported crystallographic and in vitro inhibition studies of FTO with known 2OG oxygenase inhibitors including $20 \mathrm{OG}$ competitors/analogues (2-4) and

Received: July 6, 2021

Published: November 11, 2021 
A

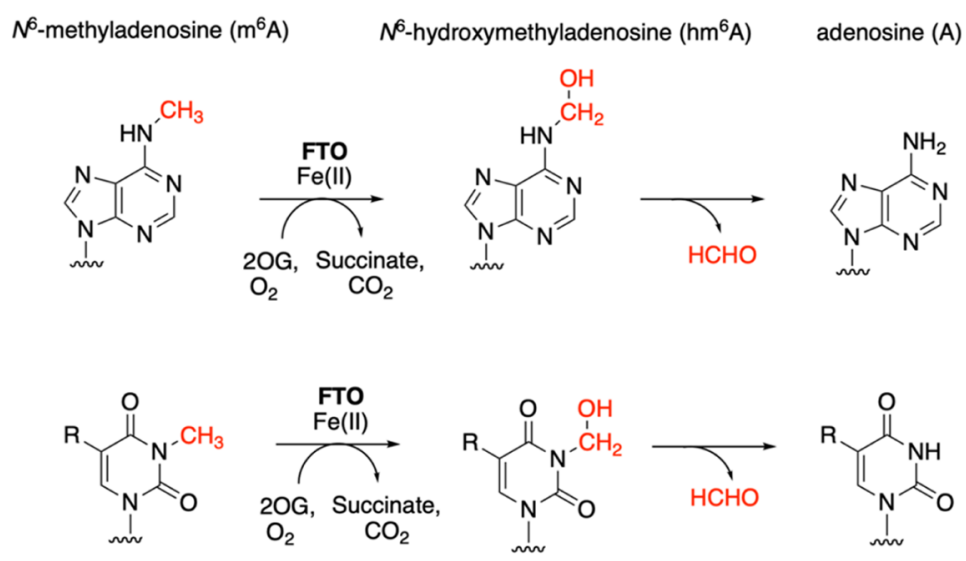

$\mathrm{R}=\mathrm{H}, \boldsymbol{N}^{3}$-methyluridine $\left(\mathrm{m}^{3} \mathrm{U}\right)$ $\mathrm{R}=\mathrm{CH}_{3}, N^{\beta}$-methylthymidine $\left(\mathrm{m}^{3} \mathrm{~T}\right)$

$\mathrm{R}=\mathrm{H}, \boldsymbol{N}^{\beta}$-hydroxymethyluridine $\left(\mathrm{hm}^{3} \mathrm{U}\right) \quad \mathrm{R}=\mathrm{H}$, uridine $(\mathrm{U})$ $\mathrm{R}=\mathrm{CH}_{3}, N^{\beta}$-hydroxymethylthymidine $\left(\mathrm{hm}^{3} \mathrm{~T}\right) \quad \mathrm{R}=\mathrm{CH}_{3}$, thymidine $(\mathrm{T})$

B

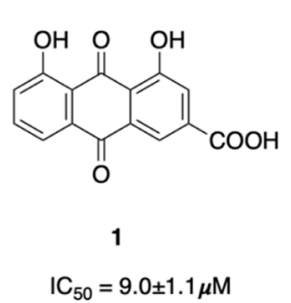<smiles>O=C(O)CNC(=O)c1nc(Cl)c2ccccc2c1O</smiles>

2

$\mathrm{IC}_{50}=2.8 \pm 0.9 \mu \mathrm{M}$<smiles>O=C(O)c1ccc(O)c2ncccc12</smiles>

3

$\mathrm{IC}_{50}=3.3 \pm 1.1 \mu \mathrm{M}$<smiles>O=C(O)CNC(=O)c1ncccc1O</smiles><smiles>O=C(O)CNC(=O)C(=O)O</smiles>

4

$\mathrm{IC}_{50}=15 \pm 1.1 \mu \mathrm{M}$

Figure 1. (A) Schematic representation of FTO-catalyzed reactions. (B) Reported FTO inhibitors with $\mathrm{IC}_{50}{ }^{26}$ values against FTO (determined using an $\mathrm{LC}$ assay with the $\mathrm{m}^{3} \mathrm{~T}$ nucleoside as a substrate). ${ }^{26}$

rhein (1) (Figure 1B). ${ }^{26,27}$ The most potent FTO inhibitor identified, FG-2216 (2, $\left.\mathrm{IC}_{50} 3 \mu \mathrm{M}\right)$, is a PHD inhibitor. ${ }^{28}$ Treatment of mice with FG-2216 (2) led to reduced bone mineral density and altered adipose tissue density distribution without affecting body weight or respiratory exchange ratio. ${ }^{29}$ Structures of FTO in complex with 3 (FTO IC $_{50} 3.3 \mu \mathrm{M}$ ) and 4 (FTO IC $\left._{50} 15 \mu \mathrm{M}\right)$ were also obtained. ${ }^{26} 3$ was reported as a broad spectrum inhibitor of the $\mathrm{JmjC}$ histone lysine demethylases (KDM2A, 3A, 4A-E, 5C, 6A, and B, 7B: $\mathrm{IC}_{50}$ $0.2-25 \mu \mathrm{M})$ and inhibits the bacterial NAOX AlkB $\left(\mathrm{IC}_{50} 3.4\right.$ $\mu \mathrm{M}){ }^{26,30,31}$ The reported FTO inhibitors thus likely do not have the potency or selectivity required for in vivo target validation of FTO. Here, we report the use of structural knowledge of how FTO binds 2OG and substrate to design potent and, at least partially selective, FTO inhibitors.

\section{RESULTS}

During 2OG oxygenase catalysis, binding of $20 \mathrm{O}$ in a bidentate manner to the active site $\mathrm{Fe}$ (II) is followed by that of the substrate, and then dioxygen. ${ }^{12}$ One strategy in $2 \mathrm{OG}$ oxygenase inhibitor design has been to covalently link a nonreactive $20 G$ mimetic with a group occupying the substrate binding site, so yielding more potent and selective inhibitors than the independent fragments. ${ }^{32,33}$ Unlike $\mathbf{2 - 5}$, which bind in the 2OG binding pocket of FTO, rhein (1) occupies the nucleobase binding site. ${ }^{26}$ A comparison of the FTO and 4 (a glycyl-hydroxypyridine 2OG mimic) and FTO and rhein $(\mathbf{1})^{26}$ structural complexes indicates that the hydroxypyridinyl ring of 4 is proximate to the anthraquinone ring of rhein (1), which binds competitively with the substrate nucleobase (Figures $2 \mathrm{~A}$ and S2). Based on this analysis, we designed and synthesized a series of derivatives of 4 (Table 1) predicted to extend into the substrate binding site by functionalization at the C-6 position (13a-d) (Figure 2A, Scheme 1). 3-Hydroxypicolinonitrile was used as the starting material for C-6 derivatization of 4. C-6 halogenation of the pyridine ring of hydroxypicolinonitrile, followed by hydrolysis of the nitrile gave 6-bromo-3hydroxypicolinic acid (7), which was coupled with a protected glycine amide (glycine tert-butyl ester hydrochloride or glycine phenyl ester hydrochloride). The resulting compounds were coupled to different aryl rings by Suzuki or Buchwald couplings, then deprotected to give the desired acids $(13 a-d$ and $14 a-i)$.

We initially tested the in vitro inhibitory activity of $13 a-d$ against FTO $(1.2 \mu \mathrm{M})$ using a reported liquid chromatography (LC)-based assay employing the $\mathrm{m}^{3} \mathrm{~T}$ nucleoside as a substrate. ${ }^{26} 13 \mathrm{a}\left(\mathrm{IC}_{50} 35 \pm 1 \mu \mathrm{M}\right)$, with a phenyl ring at $\mathrm{C}$ 6 was slightly less potent than $4\left(\mathrm{IC}_{50} 15 \mu \mathrm{M}\right)$ against FTO. 13a and $13 \mathbf{b}\left(\mathrm{IC}_{50} 15 \pm 1 \mu \mathrm{M}\right)$ had potencies similar to that of 4 against PHD2 and FTO; however, 13a showed little or no inhibition $\left(\mathrm{IC}_{50}>100 \mu \mathrm{M}\right)$ toward the 2OG-dependent JmjC KDMs, KDM3A, KDM4C, and KDM6B and showed limited activity $\left(\mathrm{IC}_{50} \mathrm{~s} 34-88 \mu \mathrm{M}\right)$ toward KDM5A, B, C, and KDM2A (Tables 1 and S2). The introduction of a biphenyl ring at C-6 of the pyridine ring (13b) resulted in moderate FTO inhibition $\left(\mathrm{IC}_{50} 15 \pm 1 \mu \mathrm{M}\right)$, while manifesting an increased inhibition of the other tested 2OG oxygenases (PHD2, FIH, KDM3A, KDM4C, KDM6B, KDM5A, KDM5B, KDM5C, KDM5D, and KDM2A) compared to 13a (Tables 1 and S2). Substitution at C-6 of the pyridine with 1naphthalene $(13 \mathrm{c})$ gave more potent inhibition $\left(\mathrm{IC}_{50} 4 \pm 1\right.$ $\mu \mathrm{M})$, similar to that of FG-2216 (2) ( $\left.\mathrm{IC}_{50} 2.8 \pm 0.9 \mu \mathrm{M}\right) .13 \mathrm{c}$ 

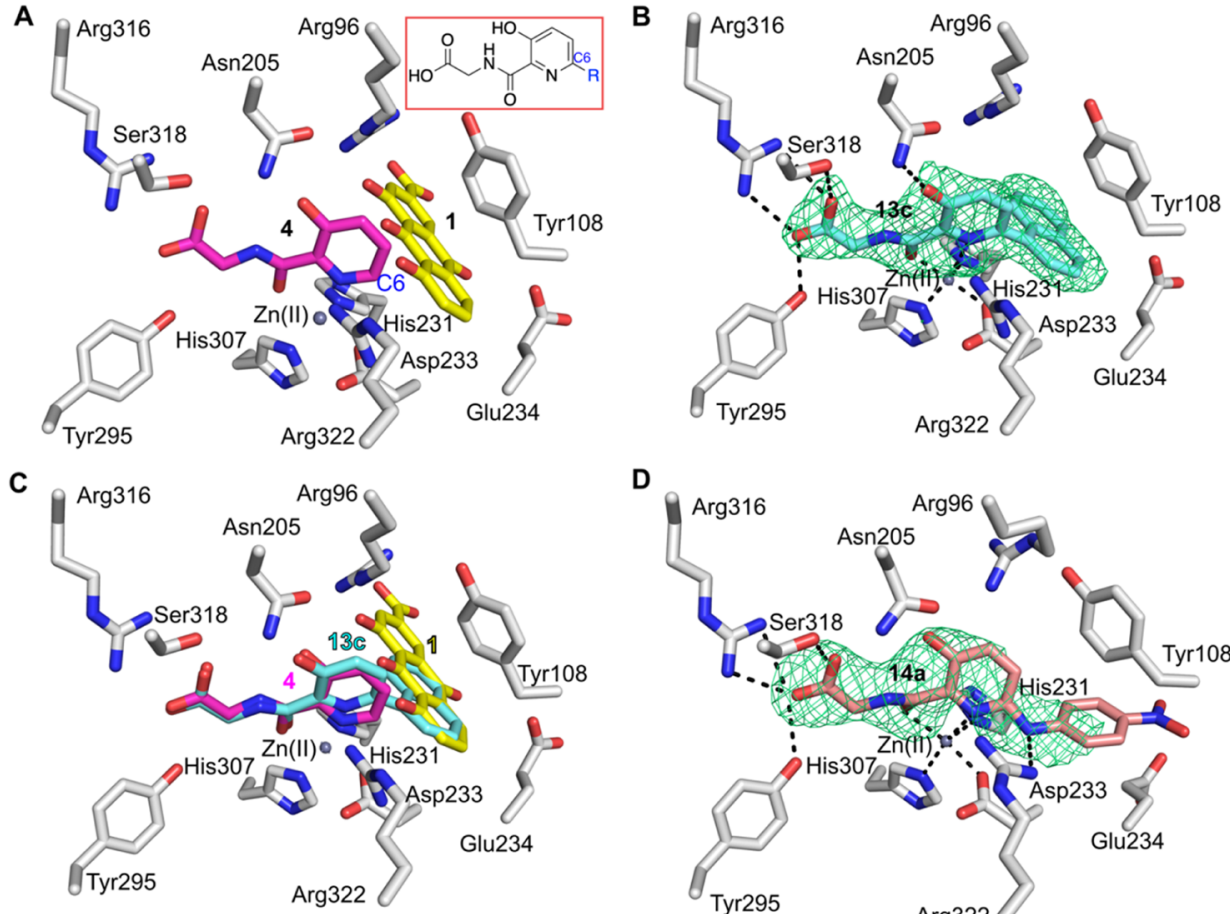

D

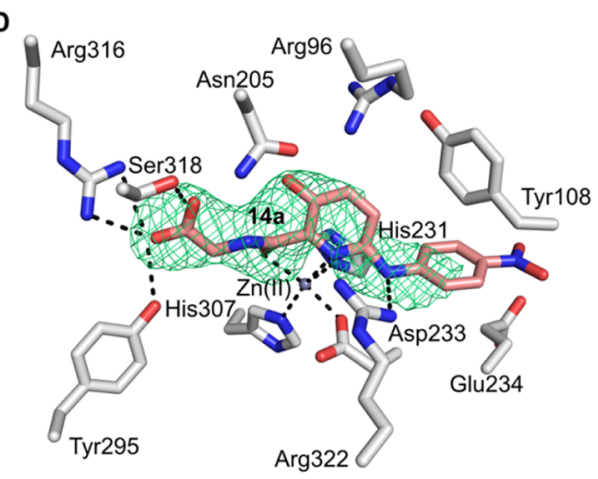

E

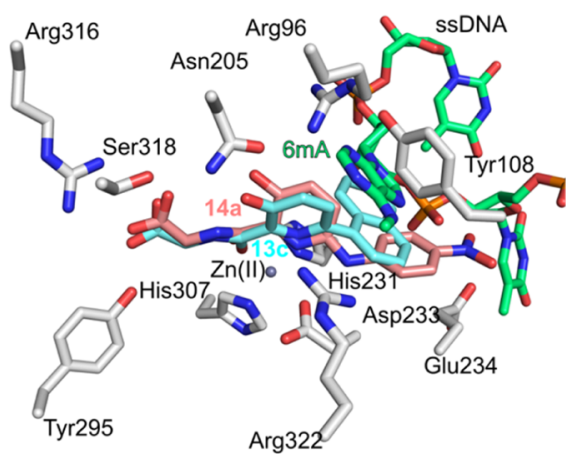

$\mathbf{F}$

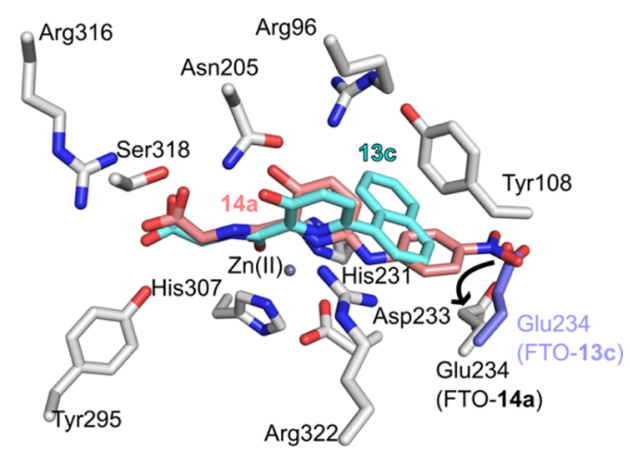

Figure 2. Structure-based FTO inhibitor design. (A) View of the active site from a crystal structure of FTO $\Delta 31$ (white sticks) in complex with 4 (magenta sticks) (PDB ID 4IE5), ${ }^{26}$ which was used as a basis for inhibitor design, with the structure of FTO $\Delta 31-1$ (rhein, yellow sticks) (PDB ID 4IE7 $)^{26}$ superimposed. The inset indicates how the derivatization of 4 at C6 could enable inhibition by combining fragments of $2 \mathrm{OG}$ and nucleobase mimetics. (B) View of the active site from a structure of FTO $\Delta 31$ (white sticks) in complex with 13c (cyan sticks surrounded by OMIT $\mathrm{mF}_{\mathrm{o}}-\mathrm{DF}_{\mathrm{c}}$ electron density displayed as green mesh, contoured to 3.0 $\sigma$ ). (C) Superimposition of a structure of FTO $\Delta 31-13 \mathrm{c}$ with that of FTO $\Delta 31-$ 4 (PDB ID 4IE5; 4 in magenta) and FTO $\Delta 31-1$ (PDB ID 4IE7, 1 in yellow). (D) View of the active site of FTO in complex with 14a. The FTO $\Delta 31$ active site (white sticks) showing OMIT electron density $\left(\mathrm{mF}_{\mathrm{o}}-\mathrm{DF}_{\mathrm{c}}\right.$, contoured to $3.0 \sigma$ in a green mesh) around 14a (salmon sticks). (E) View of superimposed structures of FTO $\Delta 31-13 \mathrm{c}$ (PDB ID 4QHO, 13c cyan sticks), FTO $\Delta 31-14 \mathrm{a}$, and a FTO-ssDNA substrate (lime green sticks) complex (PDB ID: 5ZMD). Only FTO residues (white sticks) from the FTO $\Delta 31-14 a$ structural complex are shown. (F) Superimposed structures of FTO $\Delta 31-13 \mathrm{c}$ (PDB ID 4QHO, 13c cyan sticks) and FTO $\Delta 31-14 a$. Residues from FTO $\Delta 31-14 a$ are white sticks; the substrate binding Glu234 side chain from FTO $\Delta 31-13 \mathrm{c}$ is highlighted in purple sticks. Note: the nitro-phenyl group of 14a displaces the substrate binding Glu234 side chain. Non-carbon atoms colored: O (red), N (blue), Zn (gray sphere), and H-bond, electrostatic and metal coordination interactions are indicated as black dashes.

was, however, more selective for FTO, compared to 2 and the other compounds in this series over the JmjC KDMs. Quinoline derivative $13 \mathbf{d}$ was prepared as a more basic and water-soluble analogue of $13 \mathrm{c}$ but manifested a 6 -fold decrease in potency against FTO $\left(13 \mathrm{~d}, \mathrm{IC}_{50} 25 \pm 1 \mu \mathrm{M}\right)$ relative to $13 \mathrm{c}$.

To investigate the binding mode of $13 \mathrm{c}$, we obtained a structure of FTO $\Delta 31$ with $\mathrm{Zn}$ substituting for $\mathrm{Fe}$ in the complex with it (2.6 $\AA$ resolution, PDB ID 4QHO). The structure was solved by molecular replacement using an FTO-4 complex structure (PDB ID 4IE5) as a search model. There was clear electron density for $\mathbf{1 3 c}$ in the active site revealing that the hydroxypyridinyl glycyl scaffold manifests a similar binding mode to that previously observed for 4 (PDB ID 4IE5), ${ }^{26}$ with hydrogen bonding interactions occurring between the 3-hydroxy group on the pyridine ring and the Asn205 side chain and additional electrostatic and hydrogen bonding interactions between the glycyl carboxylate and the side chains of Arg316, Ser318, and Tyr295 (Figure 2B). As predicted, the 13c 1-naphthyl side chain extends to occupy the substrate binding site (Figure 2B), with the plane of its naphthyl group being near orthogonal relative to its pyridine ring. The 1-naphthyl group of $13 \mathrm{c}$ appears to form partial $\pi-\pi$ 
Table 1. IC $_{50}$ Values of Compounds against FTO and Selected Other Human 2OG Oxygenases

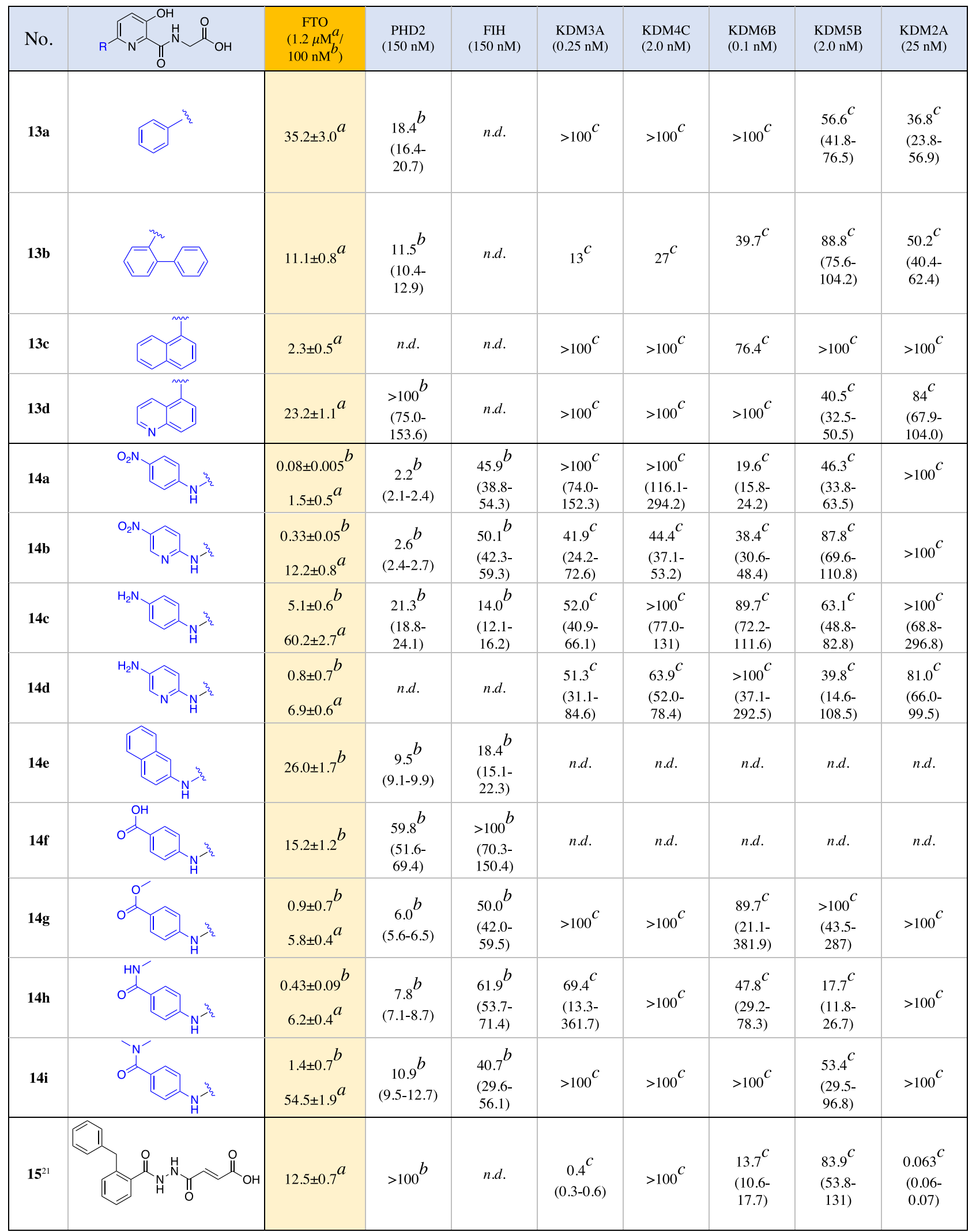

${ }^{a} \mathrm{IC}_{50}$ values (in $\mu \mathrm{M}$ ) obtained from the 5-mer $\mathrm{m}^{6} \mathrm{~A}$ RNA LCMS-based demethylation assay. ${ }^{b}$ SPE-MS-based assay. ${ }^{34}{ }^{c} \mathrm{~A}$ histone demethylase luminescence-based AlphaScreen assay. ${ }^{35}$ For SPE-MS and AlphaScreen assays, the data represent $\mathrm{IC}_{50}$ values plus lower and upper $95 \%$ confidence limits (in parentheses). Enzyme concentrations employed are stated in parentheses on the first row. The high $\mathrm{IC}_{50}$ for $14 \mathrm{c}\left(\mathrm{IC}_{50} 5.1 \mu \mathrm{M}\right)$ may in part be due its relative lack of solubility at the tested concentrations. Note: n.d., not determined. 


\section{Scheme 1. Synthesis of FTO inhibitors ${ }^{a}$}

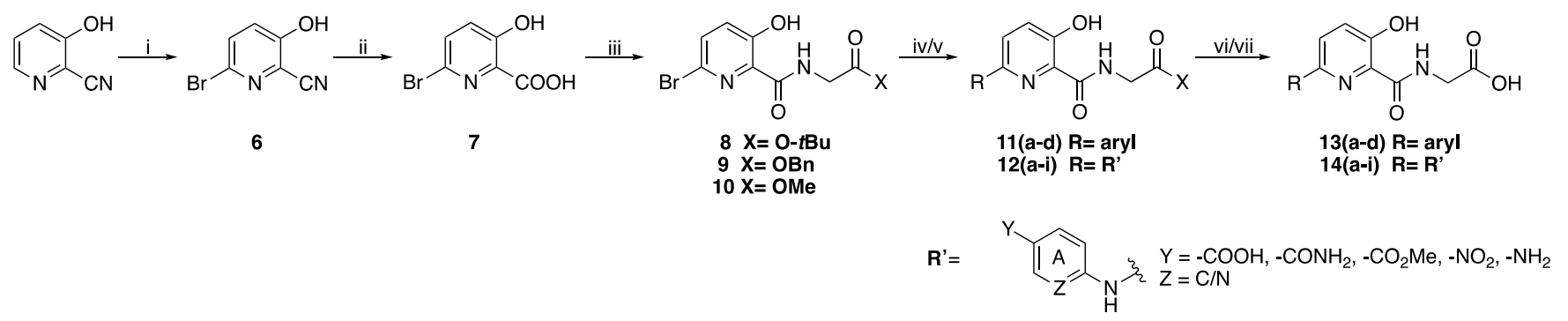

${ }^{a}$ Suzuki or Buchwald-Hartwig Pd-couplings were used to couple the C-6 position of the pyridinyl ring with different aryl rings/aryl amines. Reagents and conditions: (i) $\mathrm{Br}_{2}$ (1.1 equiv), $\mathrm{H}_{2} \mathrm{O}, 3$ days; (ii) $\mathrm{NaOH} 30 \%, \mathrm{MeOH}$, reflux, $12 \mathrm{~h}$; (iii) $\mathrm{GlyOC}\left(\mathrm{CH}_{3}\right)_{3}$ or $\mathrm{GlyOCH}_{3}$, or GlyOCH $\mathrm{Ph}_{2}$ (1.5 equiv), propylphosphonic anhydride ( 1.5 equiv), diisopropylethylamine (4 equiv), microwave, $4 \mathrm{~h}$; (iv) $\mathrm{RB}(\mathrm{OH})_{2}(1.3 \mathrm{equiv}), \mathrm{K}_{2} \mathrm{CO}_{3}(4$ equiv), $\mathrm{Pd}\left(\mathrm{PPh}_{3}\right)_{4}(10 \mathrm{~mol} \%)$, microwave, $130{ }^{\circ} \mathrm{C}$; (v) $\mathrm{ArNH}_{2}$ (1.2 equiv), BrettPhos (0.15 equiv), BrettPhosLigand G1 (0.01 equiv), $\mathrm{K}_{3} \mathrm{PO}_{4}(1.2$ equiv); (vi) $\mathrm{KOH}$ (excess), THF; (vii) Pd/C (10 mol\%), THF, r.t.

interactions with the indole side chain of His231. The superimposition of the structures of FTO $\Delta 31$ in complex with 4,1 , and $13 \mathrm{c}$, show a substantial overlap, in particular the naphthyl group of $13 \mathrm{c}$ is positioned similar to two of the three anthraquinone rings of rhein (1) (Figure 2C).

Because 13c showed enhanced potency and higher selectivity compared to reported FTO inhibitors, we used the FTO $\Delta 31-13 \mathrm{c}$ structure as a basis for the design of further inhibitors. Analyses of the FTO $\Delta 31-13 \mathrm{c}$ structure suggests that the introduction of a heteroatom between the pyridinyl ring and the C- 6 aryl substituent of the original series would provide additional side chain flexibility and potentially position the aryl ring between the side chains of Tyr106 and Tyr108.

Buchwald-Hartwig coupling was thus used to prepare the aniline derivatives $(\mathbf{1 4 a}-\mathbf{i})$, which were tested against FTO and 10 other $2 \mathrm{OG}$ oxygenases (Tables 1 and S2). We initially employed an optimized LCMS-based assay using a 5-mer $\mathrm{m}^{6} \mathrm{~A}$ RNA oligonucleotide as the substrate and $1.2 \mu \mathrm{M}$ FTO (Figure S3) to investigate the $\mathrm{IC}_{50} \mathrm{~s}$ of $13 \mathrm{a}-\mathrm{d}, 14 \mathrm{a}-\mathrm{d}, 14 \mathrm{~g}-\mathrm{i}$, and 15 (a reported FTO inhibitor). ${ }^{21}$ The $\mathrm{IC}_{50} \mathrm{~s}$ of $\mathbf{1 4 a - d}$ and $\mathbf{g}-\mathbf{i}$ range from 1.5 to $60.2 \mu \mathrm{M}$, with the majority displaying increased potencies over 13a-d (2.3-35.2 $\mu \mathrm{M})$ (Table 1). The most potent of the tested FTO inhibitors was $14 a\left(\mathrm{IC}_{50}\right.$ $1.5 \mu \mathrm{M}$ ), which has a $p$-nitrophenyl side chain (Table 1 ). Against the panel of $2 \mathrm{OG}$ oxygenases, $14 \mathbf{a}-\mathbf{d}$ and $\mathbf{g}-\mathbf{i}$ showed generally greater selectivity than $\mathbf{1 3 a}-\mathbf{d}$ toward FTO. For the majority of JmjC KDMs screened, $\mathrm{IC}_{50}$ values were in the tens of $\mu \mathrm{M}$ to $>100 \mu \mathrm{M}$. The selectivity of the $14 a-d$ and $\mathbf{g}-\mathbf{i}$ series for FTO over PHD2 was less pronounced $\left(\mathrm{IC}_{50}\right.$ range 2.2-59.8 $\mu \mathrm{M}$ ) but with the most potent FTO inhibitor, 14a, being $~ 30$-fold more selective for FTO over PHD2 under the tested conditions.

With the LCMS-based assays, the $\mathrm{IC}_{50}$ measurement of $14 \mathrm{a}$ $(1.5 \mu \mathrm{M})$ was limited as it was near the FTO concentration $(1.2 \mu \mathrm{M})$. We thus developed a more sensitive hydroxylation assay employing a lower FTO concentration (100 nM) with a solid-phase extraction coupled to MS (SPE-MS) assay (Figure S4, Table 1). Instead of demethylation, this assay monitors the hydroxylated product (hydroxymethyladenine, $\mathrm{hm}^{6} \mathrm{~A}$ ) of a 15 mer $\mathrm{m}^{6} \mathrm{~A}$-containing RNA oligonucleotide $\left(\mathrm{hm}^{6} \mathrm{~A}\right.$ has been reported to be a relatively stable adduct). ${ }^{17,19}$ We determined the $\mathrm{IC}_{50}$ s of $14 \mathrm{a}-\mathbf{i}$ using SPE-MS.

The SPE-MS results show that the two compounds with $p$ nitrophenyl/p-nitropyridinyl groups at C-6 of the core pyridine, that is, $\mathbf{1 4 a} / \mathbf{1 4 b}$, are the most potent of the FTO inhibitors $\left(\mathrm{IC}_{50} \mathrm{~s} 80\right.$ and $330 \mathrm{nM}$, respectively), followed by the
$N$-methyl amide-phenyl (14h, $\left.\mathrm{IC}_{50} 430 \mathrm{nM}\right)$, amine-pyridyl (14d, $800 \mathrm{nM})$, ester (14g, $900 \mathrm{nM}), N$-dimethyl amidephenyl $(14 \mathrm{i}, 1.4 \mu \mathrm{M})$, and amine-phenyl $\left(14 \mathrm{c}, \mathrm{IC}_{50}=5.1 \mu \mathrm{M}\right)$ C-6 substituents. The compounds with benzoic acid $\mathbf{1 4 f}$ and naphthylamine 14e side chains were the weakest FTO inhibitors $\left(\mathrm{IC}_{50} \mathrm{~s} 15.2\right.$ and $26 \mu \mathrm{M}$, respectively). Even though the C-6 nitro-pyridine analogue $(\mathbf{1 4 b})$ has a 4-fold higher $\mathrm{IC}_{50}$ than the nitro-phenyl analogue 14a, the amine-pyridine substituent $14 \mathrm{~d}$ has a lower $\mathrm{IC}_{50}$ than the amine-phenyl derivative 14c, thus pyridines at C-6 can be productively accommodated within the active site.

Changing the para-nitro group of the C-6 phenyl ring of 14a to an amide, as in the monomethyl amide $14 \mathrm{~h}\left(\mathrm{IC}_{50} 430 \mathrm{nM}\right)$ or dimethyl amide $14 \mathrm{i}\left(\mathrm{IC}_{50} 1.4 \mu \mathrm{M}\right)$ increases the $\mathrm{IC}_{50}$ values by $\sim 5-18$ fold over $14 a$, respectively. In general, substituting the nitro group of 14a (amine: 14c and 14d; amide: 14h and $\mathbf{1 4} \mathbf{i}$; carboxylate: $\mathbf{1 4 f}$; and ester: $\mathbf{1 4 g}$ ) resulted in a reduction in potency.

The results of testing $13 \mathbf{a}-\mathbf{d}, \mathbf{1 4 a}-\mathbf{i}$, and a previously reported selective FTO inhibitor $15,{ }^{21}$ against a panel of human 2OG oxygenases (Tables 1 and S2) revealed that, except for hydrazine compound 15 (FTO IC $_{50} 12.5 \pm 0.7 \mu \mathrm{M}$; LCMS-based assay), the hydroxy pyridine-glycyl compounds were for the most part selective for FTO and PHD2. Interestingly, $\mathbf{1 5}$ was identified as a potent inhibitor of the histone $\mathrm{H} 3$ lysine $36 \mathrm{JmjC} \mathrm{KDM} 2 \mathrm{~A}\left(\mathrm{IC}_{50} 63 \mathrm{nM}\right)$, which is a potential cancer target. ${ }^{36,37}$

To confirm that the compounds inhibit FTO by binding at the active site, we performed a competition-based NMR binding assay ${ }^{38}$ (using 2OG as a competitor) to obtain binding constants for the selected compounds (13c, 14a, 14h, and 14i) (Figures S5 and S6). The rankings of the $K_{\mathrm{D}}$ values were generally in accord with the rankings of the $\mathrm{IC}_{50}$ values: 14a $\left(K_{\mathrm{D}} 0.34 \pm 0.16 \mu \mathrm{M}, \mathrm{IC}_{50} 1.5 \pm 0.5 \mu \mathrm{M}\right), 13 \mathrm{c}\left(K_{\mathrm{D}} 1.2 \pm 0.24\right.$ $\left.\mu \mathrm{M}, \mathrm{IC}_{50} 2.3 \pm 0.5 \mu \mathrm{M}\right), 14 \mathrm{~h}\left(K_{\mathrm{D}} 0.67 \pm 0.29 \mu \mathrm{M}, \mathrm{IC}_{50} 6.2 \pm\right.$ $0.4 \mu \mathrm{M})$, and $14 \mathrm{i}\left(K_{\mathrm{D}} 3.9 \pm 1.6 \mu \mathrm{M}, \mathrm{IC}_{50} 54.5 \pm 1.9 \mu \mathrm{M}\right)$.

We co-crystallized FTO $\Delta 31$ with $14 a$ and determined its structure (2.6 $\AA$ resolution). The structure revealed that the hydroxypyridyl-glycine core of $\mathbf{1 4 a}$ binds, as observed for 4 , in the $2 \mathrm{OG}$ binding site (Figures $2 \mathrm{D}$ and S7). 14a coordinates to the metal ( $\mathrm{Zn}$ substituting for $\mathrm{Fe}$ ) via its pyridinyl nitrogen and the carbonyl oxygen, its glycyl carboxylate forms a salt bridge with the side chain of Arg316 and hydrogen bonds with the side chains of Ser318 and Tyr295. In the FTO $\Delta 31-14 a$ complex, the 14a carbonyl oxygen is positioned trans to the metal-coordinating residue Asp233 and the metal-coordinating 

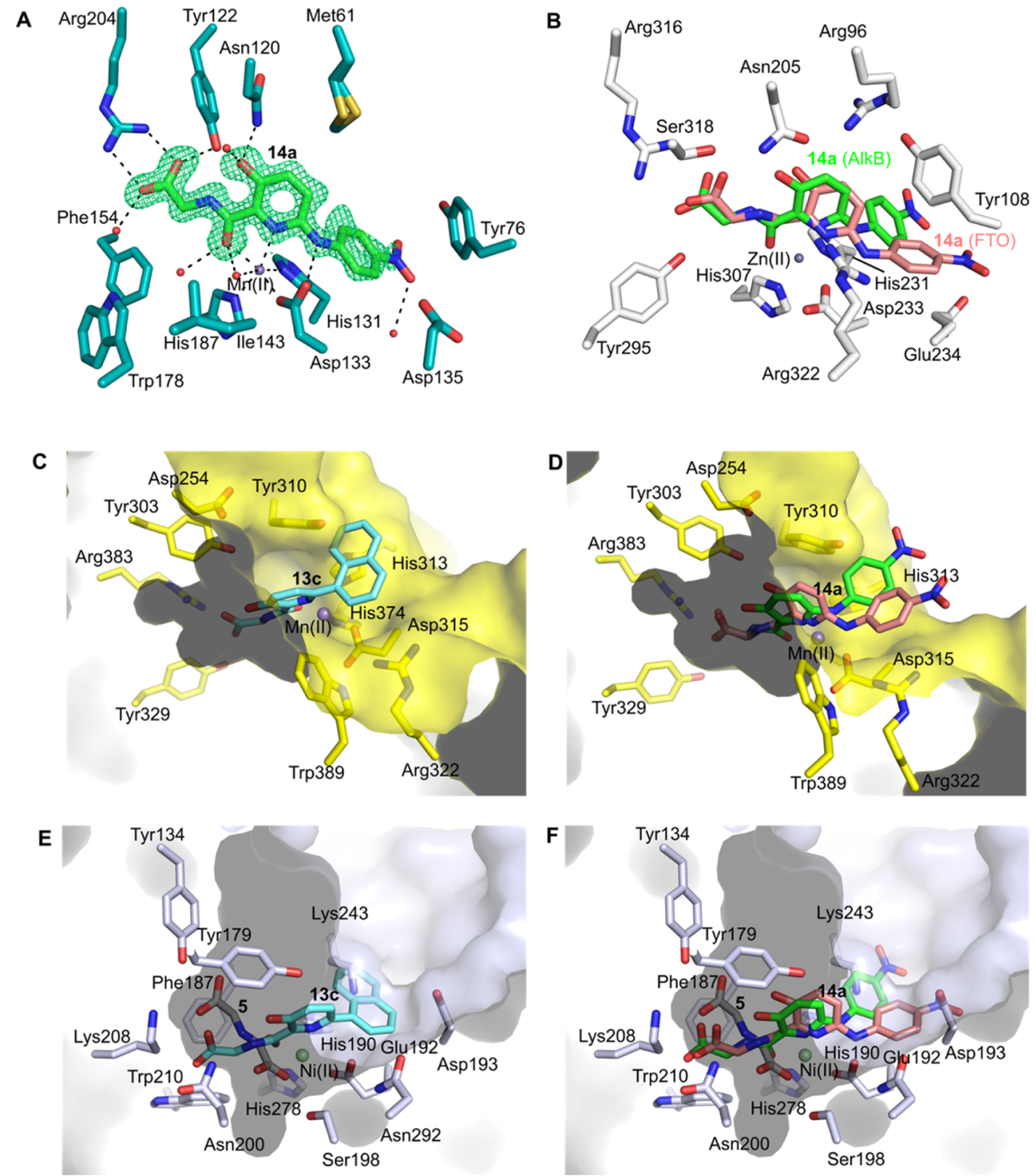

Figure 3. Structure-based rationalization of selectivity of FTO inhibitors. (A) View of the active site of the AlkB $\Delta$ N11-14a complex (PDB ID 7NRO); 14a (green sticks) with surrounding OMIT electron density $\mathrm{mF}_{\mathrm{o}}-\mathrm{DF}_{\mathrm{c}}$ shown as a green mesh and contoured to $3.0 \sigma$. (B) View of the FTO $\Delta 31-14 a$ structural complex (FTO in white sticks) (PDB ID 7E8Z) superimposed on a structure of AlkB $\Delta$ N11-14a. Note: 14a (salmon sticks, FTO; green sticks, AlkB) binds slightly differently to FTO and AlKB in particular, the metal-coordinating atoms of 14a and the metal ion are coplanar with AlkB. (C) View of the active site from a structure of truncated PHD2 (yellow sticks and surface) superimposed with a structure of FTO $\Delta 31$ in complex with 13c (PDB ID 4QHO) (derived from a structure of the PHD2-2 complex PDB ID $4 \mathrm{BQX}$, ${ }^{39}$ ligand not shown for clarity) indicating how the naphthyl side chain of $13 \mathrm{c}$ may clash with Tyr310 in the PHD2 active site, so reducing is affinity (FTO $\Delta 31$ residues are not shown for clarity). (D) View of the active sites of structures of FTO $\Delta 31$ and AlkB $\Delta$ N11 in complex with 14a (FTO, salmon sticks; AlkB, green sticks) (PDB ID 7E8Z and 7NRO) superimposed onto PHD2 (yellow sticks and surface). Note the nitrophenyl side chain of 14a is predicted to occupy the PHD2 active site opening with a potential for minor clashes, notably for the crystallographically observed AlkB 14a binding mode (green sticks). (E) View from a structure of FTO in complex with 13c superimposed onto a structure of KDM4C in complex with 5 (PDB ID $2 \mathrm{XML})^{40}$ (KDM4 C shown as light blue sticks and surface; 5 in gray sticks) showing that the side chain of 13c may clash with Lys243 of KDM4C. (F) View from complexes of FTO $\Delta 31-14 a$ (salmon sticks) and AlkB $\Delta$ N11-14a (green sticks) superimposed on the structural complex of KDM4C5 (PDB ID 2XML) ${ }^{40}$ showing how the C-6 napthyl side chain of 14a may clash with Lys243 and/or Asp193 of KDM4C. Non-carbon atoms colored: O (red), N (blue), Zn (gray sphere), Mn (purple sphere), and Ni (light green); H-bond, electrostatic, and metal coordination interactions are indicated as black dashes.

pyridine nitrogen atom is trans to the metal coordinating residue His307. The plane formed by the pyridinyl ring of 14a is skewed with respect to the plane formed by its pyridinyl nitrogen and carbonyl oxygen and the active site metal (Figure S7A,B). This orientation is unusual, especially when compared to the more typical co-planar orientation seen in the FTO $\Delta 31$ 4 structure (Figure S7B).
To investigate the generality of the skewed binding mode of 14a as observed with FTO, we solved a crystal structure of a truncated version of the related bacterial NAOX AlkB $(\mathrm{AlkB} \Delta \mathrm{N} 11)$ in complex with it (Figure 3A). By contrast with the crystallographically observed FTO binding mode of 14a, in the AlkB-14a structure, the metal-coordinating atoms of 14a and the metal-ion are co-planar with the pyridinyl ring (Figure 3B). Contrary to the binding mode observed with 
FTO, the $p$-nitrophenyl group of $\mathbf{1 4 a}$ is directed way from the center of the AlkB active site without significantly displacing key substrate binding side chains (Figure 3A,B). The binding mode of 14a in AlkB is different from the previously reported potent AlkB glycinamide inhibitors where their side chains are typically positioned in a hydrophobic pocket close to $\operatorname{Trp} 178$, Ile143, and Phe154 (Figure S8). ${ }^{31}$

As predicted, the amine linker of $\mathbf{1 4 a}$ apparently enables its $p$-nitrophenyl group to have a different orientation in FTO compared to the orientation of the naphthalene of $13 \mathrm{c}$ (Figure $2 \mathrm{~F}$ ). With 14a, the nitrogen of the amine linker is positioned to potentially form a hydrogen bond with the Arg322 side chain (2.9 $\AA$ ); the Arg322 side chain is also positioned to form a cation $-\pi$ interaction with the pyridine ring of $14 a$. The $p$ nitrophenyl group of 14a is positioned between the Glu234 and Tyr108 side chains of FTO. Notably, the Glu234 side chain is displaced $\sim 5 \AA$ by the $p$-nitrophenyl moiety toward the surface of the protein (Figures $2 \mathrm{~F}$ and S9), an unprecedented observation in available FTO inhibitor structures (Figure 2). ${ }^{7,20,21,23-26,41}$ Glu234 is important as it has also been shown to interact with $\mathrm{m}^{6} \mathrm{~A}$ in a structure of an FTO variant in complex with a ssDNA substrate. ${ }^{42}$ Analysis of the FTO variant:ssDNA structural complex suggests that electrostatic repulsion between the negatively charged Glu234 side chain and the phenyl carboxylate of $14 \mathrm{f}\left(\mathrm{IC}_{50} 15.2 \mu \mathrm{M}\right)$ may account for the large (190-fold) difference in $\mathrm{IC}_{50}$ between the isosteres $\mathbf{1 4 a}$ and $\mathbf{1 4 f}$. Removing the inhibitor carboxylate group by substitution with a methyl ester $\mathbf{1 4 g}$ $\left(\mathrm{IC}_{50} 860 \mathrm{nM}\right)$ appeared to partially rescue potency resulting in a 10 -fold difference relative to 14a. The structural analysis implies that bulky naphthalene of $14 \mathbf{e}$ would encounter steric hindrance in the pocket of FTO where the $p$-nitrophenyl group of $14 \mathrm{a}$ is situated, explaining its significant 325 -fold lower potency $\left(\mathrm{IC}_{50} 26 \mu \mathrm{M}\right)$.

\section{DISCUSSION AND CONCLUSIONS}

Our structure-guided approach to FTO inhibition was based on the knowledge that although $\mathrm{Fe}$ (II) and 2OG binding by $2 \mathrm{OG}$ oxygenases occurs by a conserved general process, that of substrate binding varies considerably, not least because the nature of the substrates varies for different sub-families of human $2 \mathrm{OG}$ oxygenases. ${ }^{12,15}$ Following analysis of structures of FTO in complex with a $20 \mathrm{O}$ mimic (4) and rhein (1), which binds competitively with the substrate nucleobase (Figure S2), this approach resulted in compounds (e.g., 13b and c) which were more potent than 4 . Following crystallographic studies of FTO with 13c, derivatives of 4 were further optimized to highly potent FTO inhibitors such as 14a, the proposed general binding mode of which was also validated by crystallographic analyses. The 2OG-competing inhibition mode of these inhibitors was supported by NMR studies.

Importantly, although there is likely scope for further optimization using a larger set of $20 \mathrm{O}$ oxygenases in counter screening, some of the compounds we developed show selectivity for FTO (Tables 1 and S2), which in some cases can be rationalized on the basis of structural information. For instance, the set of compounds with an aryl ring directly linked to C-6 of the pyridine ring of the scaffold $(13 a-d)$ are generally more selective for FTO over PHD2, compared to $14 \mathbf{a}-\mathbf{i}$ where the aryl ring is linked to the pyridine C-6 via an amine. The superimposition of our FTO $\Delta 31-13 c$ structural complex with that of PHD2-2 ${ }^{39}$ reveals that the C-6 aryl ring of 13c will likely clash with the PHD2 Tyr310 side chain (Figure
$3 \mathrm{C})$, thus rationalizing in part why this set of FTO inhibitors is selective toward FTO over PHD2. In contrast, the superimposition of the FTO $\Delta 31-14 \mathrm{a}$ and AlkB-14a structures with the PHD2-2 structure reveals that the nitrophenyl group of 14a will likely project into an unoccupied space at the active site entrance of PHD2 (Figure 3D). The lack of steric hindrance for the C-6 aryl ring of 14a (and by implication) when modeled in PHD2 is thus proposed to lower its selectivity toward FTO over PHD2. The superimposition of the structural complexes of FTO $\Delta 31-13 \mathrm{c}$, FTO $\Delta 31-14 a$, and AlkB $\Delta \mathrm{N} 11-14 \mathrm{a}$ with $\mathrm{KDM} 4 \mathrm{C}-5$ as a representative of JmjC oxygenases suggests that similar steric clashes of 14a proposed for PHD2 may also occur in the KDM4C active site (Figure $3 \mathrm{E}, \mathrm{F})$. The superimposed structures also reveal that the hydroxypyridinyl compounds adopt a different metal-ion binding mode as $\mathbf{5}$ does with $\mathrm{KDM} 4 \mathrm{C}$, potentially providing a structural explanation for the selectivity of the C-6 substituted hydroxypyridine compounds for FTO over the JmjC sub-family of $2 \mathrm{OG}$ oxygenases.

It should, however, be noted that apparently clear crystallographically based structural explanations for the selectivity of inhibitors for particular 2OG oxygenases do not always manifest in experimental studies, as shown by the results with PHD inhibitors ${ }^{43-46}$ and some of our results for $\mathrm{JmjC}$ KDM inhibition (Tables 1 and S2). In this regard, it is important to note that, both in terms of 2OG and substrate binding by $20 \mathrm{G}$ oxygenases, there is substantial evidence for conformational changes, as exemplified with PHD2, where such changes help enable a mechanism employing an ordered sequential active site binding of 2OG, substrate, and then dioxygen. ${ }^{43,44}$ Such conformational changes, at least in some cases, are observed on inhibitor binding, as observed with the PHDs. ${ }^{45,46}$ Further, with the JmjC KDMs, in some cases there is evidence for the inhibitor-induced $\mathrm{Fe}$ (II) movement. ${ }^{30}$ In the case of FTO, our structure with 14a, provides evidence that the side chain of Glu234, which is likely important in catalysis, is susceptible to conformational changes (Figures $2 \mathrm{~F}$ and S8). In the case of the structure of the complex of FTO $\Delta 31-14 a$, a skewed inhibitor binding mode was observed; the skewed binding was less apparent in a structure of the bacterial NAOX AlkB $\Delta$ N11 in complex with 14a. Although further detailed work is required to define the precise binding mode of 14a to FTO in solution (perhaps employing NMR), our observations illustrate why the crystallographic information should be used with care and highlight the importance of solution and empirical inhibition studies.

Nonetheless, the combined results illustrate how the knowledge of the 2OG cosubstrate and prime substrate binding modes as revealed by high-resolution crystallographic analyses can be combined to develop potent inhibitors of FTO, which is a human 2OG oxygenase of current therapeutic interest. Future work can now be directed toward the optimization of the compounds described here for in vivo studies aimed at defining how the reactions catalyzed by FTO are linked to its roles in physiology and disease.

\section{EXPERIMENTAL SECTION}

Recombinant FTO and FTO $\Delta 31$ Production and Purification. The production and purification of FTO and FTO $\Delta 31$ were carried out as reported. ${ }^{26}$ Escherichia coli BL21 (DE3) cells (or E. coli Rosetta (DE3) pLysS cells for FTO $\Delta 31$-14a) were transformed with the pET28a_FTO plasmid (encoding for N-terminally hexahistidinetagged full-length human FTO without the thrombin cleavage site 
between the hexahistidine tag and the protein) or pET28a FTO FTO $\Delta 31$ (encoding for N-terminally hexahistidine-tagged human FTO with residues $2-31$ deleted from the $\mathrm{N}$-terminus) and were grown $\left(37^{\circ} \mathrm{C} ; 180 \mathrm{rpm}\right)$ to an $\mathrm{OD}_{600}$ of $0.6-0.8$. FTO production was induced by the addition of a final concentration of $0.5 \mathrm{mM}$ isopropyl $\beta$-D-1-thiogalactopyranoside (IPTG); growth was continued at $16{ }^{\circ} \mathrm{C}$ for $16 \mathrm{~h}(\mathrm{FTO})$ or $18{ }^{\circ} \mathrm{C}$ for $8 \mathrm{~h}($ FTO $\Delta 31)$. The resultant cell pellets were stored at $-80{ }^{\circ} \mathrm{C}$. The cell pellets were thawed and resuspended in $20 \mathrm{mM}$ Tris, $\mathrm{pH} 7.5 ; 500 \mathrm{mM} \mathrm{NaCl} ; 10 \mathrm{mM}$ imidazole, and $1 \mathrm{mg}$ of DNaseI, $10 \mathrm{mM} \mathrm{MgCl}$, and a Roche cOmplete protease inhibitor tablet (or $17.8 \mu \mathrm{g} / \mathrm{mL}$ phenylmethylsulfonyl fluoride for FTO $\Delta 31-14 a$ ) then lysed by sonication on ice. The lysates were cleared by centrifugation, and the supernatant was loaded onto a $5 \mathrm{~mL}$ HisTrap column (Cytiva) and purified using an AKTA FPLC system. The column was treated with $20 \mathrm{mM}$ Tris, $\mathrm{pH}$ 7.5; 500 $\mathrm{mM} \mathrm{NaCl}$; and $40 \mathrm{mM}$ imidazole, then eluted with $20 \mathrm{mM}$ Tris, $\mathrm{pH}$ 7.5; $500 \mathrm{mM} \mathrm{NaCl}$; and $500 \mathrm{mM}$ imidazole. The FTO solution was then buffer-exchanged into $25 \mathrm{mM}$ Tris, $\mathrm{pH} 7.5$, and concentrated to $20-40 \mathrm{mg} / \mathrm{mL}$ for storage. For crystallographic studies, the eluted FTO $\Delta 31$ from the HisTrap column was treated with EDTA (final concentration $200 \mathrm{mM}$ ) and incubated on ice for $30 \mathrm{~min}$. The FTO $\Delta 31$ solution was desalted using a PD- 10 desalting column with buffer A ( $25 \mathrm{mM}$ Tris, $\mathrm{pH} 7.5)$, then further purified by a $5 \mathrm{~mL}$ HiTrap Heparin column (Cytiva), followed by a MonoQ column (Cytiva); both columns were equilibrated with buffer A $(25 \mathrm{mM}$ Tris-HCl, pH7.5) and eluted with a gradient from 0 to $100 \%$ buffer B (25 mM Tris, $\mathrm{pH} 7.5 ; 1 \mathrm{M} \mathrm{NaCl}$ ) for heparin chromatography and 0 to $60 \%$ buffer $\mathrm{B}$ for MonoQ ion exchange chromatography. The purified protein was then buffer-exchanged into buffer $A$ and concentrated to $20 \mathrm{mg} / \mathrm{mL}$ for FTO $\Delta 31-13 \mathrm{c}$ and $36 \mathrm{mg} / \mathrm{mL}$ for FTO $\Delta 31-14 a$. The protein was snap frozen in liquid nitrogen and stored at $-80{ }^{\circ} \mathrm{C}$.

Purification of the FTO $\Delta 31-14$ a Complex. A final concentration of $8 \mathrm{mg} / \mathrm{mL}$ of FTO $\Delta 31$ was mixed with a final concentration of $1 \mathrm{mM} \mathrm{ZnSO}$ and a final concentration of $1 \mathrm{mM} \mathrm{14a}$ in $25 \mathrm{mM}$ Tris, $\mathrm{pH} 7.5$, then incubated on ice for $30 \mathrm{~min}$. The solution was loaded onto a Superdex 200 increase 10/300 GL column (Cytiva), pre-equilibrated with $25 \mathrm{mM}$ Tris, $\mathrm{pH} 7.5$, for purification using size exclusion chromatography. Relevant fractions corresponding to the FTO $\Delta 31-14$ a complex were pooled and concentrated to $10 \mathrm{mg} / \mathrm{mL}$.

AlkB $\Delta \mathrm{N} 11$ Expression and Purification for Crystallographic Studies. AlkB $\Delta$ N11 was produced and purified as described. ${ }^{31}$ In brief, E. coli BL21 (DE3) cells were transformed with $\mathrm{pE}$ T24a_AlkB $\Delta \mathrm{N} 11$ and allowed to grow at $37{ }^{\circ} \mathrm{C}$ until the $\mathrm{OD}_{600}$ reached 0.6 at which point $\mathrm{AlkB} \Delta \mathrm{N} 11$ production was induced with a final concentration of $0.5 \mathrm{mM}$ IPTG. The cells were incubated at 18 ${ }^{\circ} \mathrm{C}, 180 \mathrm{rpm}$ overnight (ca. $18 \mathrm{~h}$ ). Cells pellets were thawed and resuspended to homogeneity in $0.1 \mathrm{M} \mathrm{MES} \mathrm{pH} 5.8$ containing $1 \mathrm{mM}$ $\mathrm{MgCl}_{2}$ with $1 \mathrm{mg}$ of DNaseI and Roche cOmplete EDTA-free protease inhibitor cocktail. Cells were lysed by sonication on ice and the supernatant was obtained by centrifugation. The cell lysates were purified by cation exchange chromatography using a $50 \mathrm{~mL} \mathrm{~S}$ Sepharose column, with elution achieved by application of a gradient to $0.1 \mathrm{M}$ MES buffer, $1 \mathrm{M} \mathrm{NaCl}, \mathrm{pH} 5.8$. The eluted protein was further purified using a $300 \mathrm{~mL}$ Superdex 75 column (Cytiva), preequilibrated in $50 \mathrm{mM}$ HEPES, $\mathrm{pH} 7.5$.

In Vitro Demethylation/Hydroxylation Assays for FTO. LCBased Assays Using the $m^{3} T$ Nucleoside. LC-based in vitro $\mathrm{m}^{3} \mathrm{~T}$ demethylation assays were performed as reported. ${ }^{26}$ For initial assays using LC with the $\mathrm{m}^{3} \mathrm{~T}$ nucleoside substrate, a $50 \mu \mathrm{L}$ of reaction mixture containing final concentrations of $3 \mu \mathrm{M}$ FTO; $70 \mu \mathrm{M} \mathrm{m}^{3} \mathrm{~T}$ nucleoside; $160 \mu \mathrm{M} 2 \mathrm{OG}$; $500 \mu \mathrm{M}$ L-ascorbate; $100 \mu \mathrm{M}$ diammonium iron(II) sulfate complex; $200 \mu \mathrm{M}$ compound (or DMSO alone in

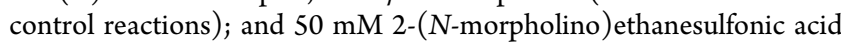
(MES), $\mathrm{pH}$ 6.3, was incubated at room temperature for $1 \mathrm{~h}$. Reactions were quenched with methanol $(50 \mu \mathrm{L})$, then centrifuged to remove the precipitated protein. The supernatant was then dried using an Eppendorf Speedvac concentrator and reconstituted with $(50 \mu \mathrm{L})$ water. The product (thymidine) and substrate $\left(\mathrm{m}^{3} \mathrm{~T}\right)$ were separated using a Waters Acquity Ultra Performance LC (UPLC) BEH C18 column (130 ̊, $1.7 \mu \mathrm{m}, 2.1 \mathrm{~mm} \times 50 \mathrm{~mm})$ with a gradient of $95 \% \mathrm{~A}$ $\left(\mathrm{H}_{2} \mathrm{O}\right.$ with $1 \%$ formic acid) to $80 \%$ B (methanol with $0.1 \%$ formic acid) over $5 \mathrm{~min}$. The UV detection wavelength was set to $266 \mathrm{~nm}$. Elution was performed at room temperature; thymidine $=0.95 \mathrm{~min}$, $\mathrm{m}^{3} \mathrm{~T}=1.48 \mathrm{~min}$. The peaks were identified in the positive ion mode using electrospray ionization-time-of-flight (ESI-TOF) mass spectrometry (Waters LCT Premier XE machine). UV peaks were integrated using MassLynx software (Agilent), and the percentage conversion of $\mathrm{m}^{3} \mathrm{~T}$ to thymidine was used to quantify the activity of FTO in the presence of inhibitors. For $\mathrm{IC}_{50}$ determinations, assays were carried out in triplicate with a range of compound concentrations $(0,10,30,100$, and $300 \mu \mathrm{M}$ and 1,3 , and $10 \mathrm{mM})$. $\mathrm{IC}_{50}$ values were calculated from dose-response curves plotted using GraphPad Prism 5.

LCMS-Based Assay Using the RNA $\mathrm{m}^{6} \mathrm{~A}$ 5-Mer Oligonucleotide. For assays using LC mass spectrometry (LC-MS) with a 5-mer ssRNA oligonucleotide substrate $\left[\mathrm{GG}\left(\mathrm{m}^{6} \mathrm{~A}\right) \mathrm{CU}\right]$ (Ella Biotech, Germany), a $25 \mu \mathrm{L}$ of reaction mixture containing final concentrations of $1.2 \mu \mathrm{M}$ FTO; $10 \mu \mathrm{M}$ 5-mer ssRNA oligonucleotide $\left[\mathrm{GG}\left(\mathrm{m}^{6} \mathrm{~A}\right) \mathrm{CU}\right] ; 10 \mu \mathrm{M} 2 \mathrm{OG} ; 500 \mu \mathrm{M}$ L-ascorbic acid; $10 \mu \mathrm{M}$ diammonium iron(II) sulfate; and $25 \mathrm{mM}$ Tris-HCl, $\mathrm{pH} 7.5$, was incubated at room temperature for $30 \mathrm{~min}$. After incubation, the reaction mixture was quenched with methanol $(25 \mu \mathrm{L})$, then centrifuged $(14,000 \mathrm{rpm}, 10 \mathrm{~min})$ in Seahorse polypropylene 96well filter microplates with a $30 \mathrm{KDa}$ molecular weight cutoff polyethersulfone membrane to remove FTO. The product [GGACU] and substrate $\left[\mathrm{GG}\left(\mathrm{m}^{6} \mathrm{~A}\right) \mathrm{CU}\right]$ were separated using a Waters Acquity UPLC Oligonucleotide BEH C-18 column $(130 \AA, 1.7 \mu \mathrm{m}, 2.1 \mathrm{~mm} \times$ $50 \mathrm{~mm}$ ) with a gradient of $98 \%$ buffer A to $70 \%$ buffer B over $8 \mathrm{~min}$, at room temperature. 1,1,1,3,3,3-Hexafluoro-2-propanol (HFIP) and triethylamine were used as an ion-pairing buffer for better separation of the 5-mer oligonucleotide substrate $\left[\mathrm{GGm}^{6} \mathrm{ACU}\right]$ and the demethylated product [GGACU]. Buffer A: 200mM HFIP, 8.15 mM TEA buffer, 5\% methanol, buffer B: $20 \%$ buffer A $+80 \%$ methanol. Separation of oligonucleotides was monitored by UV; the detection wavelength was 265-292 $\mathrm{nm}$. Retention times for [GGACU] and $\left[\mathrm{GG}\left(\mathrm{m}^{6} \mathrm{~A}\right) \mathrm{CU}\right]$ were 2.5 and $3.0 \mathrm{~min}$, respectively. The masses for each peak were confirmed by ESI-TOF mass spectrometry (Bruker Daltonics, microTOF). The area under for the substrate $\left(\left[\mathrm{GG}\left(\mathrm{m}^{6} \mathrm{~A}\right) \mathrm{CU}\right]\right)$ and product $([\mathrm{GGACU}])$ peaks were integrated using data analysis software (Bruker) in the negative ion mode, and the percentage conversion of $\left[\mathrm{GG}\left(\mathrm{m}^{6} \mathrm{~A}\right) \mathrm{CU}\right]$ to [GGACU] was used to quantify the demethylation activity of FTO in the presence of inhibitors. For $\mathrm{IC}_{50}$ determinations, assays were carried out in triplicate with a range of compound concentrations $(0$, $10,30,100$, and $300 \mu \mathrm{M}$ and 1,3 , and $10 \mathrm{mM}$ ). IC $\mathrm{IC}_{50}$ values were calculated from the dose-response curves plotted using GraphPad Prism 5.

Solid-Phase Extraction Mass Spectrometry-Based Assays. For assays using solid-phase extraction mass spectrometry (SPE-MS) with a 15-mer ssRNA oligonucleotide substrate [AUUGUGG $\left(\mathrm{m}^{6} \mathrm{~A}\right)$ CUGCAGC], a $25 \mu \mathrm{L}$ of reaction mixture was added $200 \mu \mathrm{M}$ ascorbic acid; $1 \mu \mathrm{M}$ 2OG; $0.5 \mu \mathrm{M}\left(\mathrm{NH}_{4}\right)_{2} \mathrm{Fe}\left(\mathrm{SO}_{4}\right)_{2} \cdot 6 \mathrm{H}_{2} \mathrm{O} ; 25 \mathrm{mM}$ Tris, pH 7.5; $0.6 \mu \mathrm{M}$ 15-mer ssRNA substrate; and $0.1 \mu \mathrm{M}$ FTO, with a range of compound concentrations $(3,10,30,100$, and $300 \mathrm{nM}, 1$, $3,10,30$, and $100 \mu \mathrm{M})$. Reactions were incubated at $25^{\circ} \mathrm{C}$ for $10 \mathrm{~min}$ before quenching with $10 \mathrm{mM} \mathrm{MgCl}$. A RapidFire RF 365 highthroughput sampling robot (Agilent) attached to an iFunnel Agilent 6550 accurate mass quadrupole time-of-flight (Q-TOF) mass spectrometer operated in the positive ionization mode was used for sample analyses. The samples were aspirated under vacuum for $0.6 \mathrm{~s}$ and loaded onto a C-8 reverse phase solid-phase extraction (SPE) cartridge. The cartridge was washed with $6 \mathrm{mM}$ octylammonium acetate (prepared by mixing $0.1 \mathrm{M}$ of octylamine and $0.1 \mathrm{M}$ of acetic acid with $100 \mathrm{~mL}$ diethyl ether on ice; this solution was cooled to -40 ${ }^{\circ} \mathrm{C}$ resulting in OAA crystals, which were collected and washed with cold cyclohexane.) in the LC-MS grade water treated with diethyl pyrocarbonate $(5.5 \mathrm{~s}, 1.5 \mathrm{~mL} / \mathrm{min})$. The hydroxylated product [AUUGUGG $\left(\mathrm{hm}^{6} \mathrm{~A}\right) \mathrm{CUGCAGC}$ ] and the substrate [AUUGUGG$\left(\mathrm{m}^{6} \mathrm{~A}\right)$ CUGCAGC] were eluted from the SPE cartridge with $6 \mathrm{mM}$ 
OAA $80 / 20_{\mathrm{v} / \mathrm{v}}$ acetonitrile/water into a mass spectrometer $(5.5 \mathrm{~s}, 1.5$ $\mathrm{mL} / \mathrm{min})$. The SPE cartridge re-equilibrated with $6 \mathrm{mM}$ OAA in water $(0.5 \mathrm{~s}, 1.5 \mathrm{~mL} / \mathrm{min})$. Mass spectrometer parameters: capillary voltage $(4000 \mathrm{~V})$, nozzle voltage $(0 \mathrm{~V})$, fragmentor voltage $(250 \mathrm{~V})$, gas temperature $\left(280^{\circ} \mathrm{C}\right)$, gas flow $(13 \mathrm{~L} / \mathrm{min})$, nebulizer $(40 \mathrm{psi})$, sheath gas temperature $\left(350{ }^{\circ} \mathrm{C}\right)$, and sheath gas flow $(12 \mathrm{~L} / \mathrm{min})$. Signal intensities were quantified as the total ion count and analyzed using RapidFire Integrator software (Agilent). Percentage hydroxylation was calculated by comparing the ion intensities of $\mathrm{m} / \mathrm{z}$ peaks corresponding to $[\mathrm{M}-\mathrm{H}]^{3-}$ to $[\mathrm{M}+\mathrm{OH}]^{3-}: \%$ hydroxylation $=100$ $\times$ (product) $/($ substrate + product $) . \mathrm{IC}_{50}$ values were calculated from the dose-response curves plotted using GraphPad Prism 5.

PHD2 and FIH Inhibition Assays. PHD2, FIH, and KDM inhibition assays were performed using a solid-phase extraction-mass spectrometry-based methods as described. ${ }^{34} \mathrm{KDM}$ inhibition assays were performed using an AlphaScreen-based assay as described. ${ }^{35}$

NMR-Based Binding Studies. Apo-FTO was made by treatment with EDTA as follows: fractions containing purified FTO at a concentration of $>1 \mathrm{mg} / \mathrm{mL}$ in $200 \mathrm{mM}$ EDTA and $15 \mathrm{mM}$ ammonium acetate ( $\mathrm{pH} 7.0$ to 8.0$)$ was incubated overnight at $4{ }^{\circ} \mathrm{C}$, then concentrated to $2 \mathrm{~mL}$ volume using an Amicon Ultra- 4 or Amicon Ultra-15 centrifugal filtration units. Carr-Purcell-Meiboom-Gill (CPMG) displacement experiments were carried out using an AVIII 700 Bruker instrument equipped with a TCI inverse cryoprobe using $3 \mathrm{~mm}$ diameter MATCH NMR tubes with $160 \mu \mathrm{L}$ of sample volume at $298 \mathrm{~K}$. The PROJECT-CPMG sequence of Aguilar et al. was applied $\left(90^{\circ}{ }_{x}-\left[\tau-180^{\circ}{ }_{y}-\tau-90^{\circ} y-\tau-180^{\circ}{ }_{y}-\tau\right]_{n}-\text { acq }\right)^{47}$ using: total echo time $48 \mathrm{~ms}(\tau=2 \mathrm{~ms}, n=6)$; acquisition time, 2.94 $\mathrm{s}$; relaxation delay, $2 \mathrm{~s}$; and number of scans $200-400 .{ }^{38}$ Water suppression was achieved by presaturation. Samples containing 10 or $20 \mu \mathrm{M}$ of apo-FTO, $100 \mu \mathrm{M}$ of $\mathrm{Zn}(\mathrm{II}), 10$ or $20 \mu \mathrm{M}$ of $2 \mathrm{OG}$, and $20-400 \mu \mathrm{M}$ of the inhibitor buffered in $50 \mathrm{mM}$ Tris- $\mathrm{D}_{11} / \mathrm{HCl}(\mathrm{pH}$ $7.5)$ and $0.02 \% \mathrm{NaN}_{3}(\mathrm{w} / \mathrm{v})$ in $90 \% \mathrm{H}_{2} \mathrm{O}$ and $10 \% \mathrm{D}_{2} \mathrm{O}(\mathrm{v} / \mathrm{v})$ were analyzed, and the $2 \mathrm{OG}$ displacement was measured via the reappearance of free $2 \mathrm{OG}$ signals.

The percentage of the $20 \mathrm{G}$ displacement was calculated using:

$$
\% 2 \mathrm{OG} \text { displacement }=\frac{I_{2 \mathrm{OG}}-I_{2 \mathrm{OG}(0)}}{I_{2 \mathrm{OG}(\text { blank })}-I_{2 \mathrm{OG}(0)}} \times 100
$$

where, $I_{2 \mathrm{OG}}=$ integral of $2 \mathrm{OG}$ in the presence of both protein (FTO) and inhibitor; $I_{2 \mathrm{OG}(0)}=$ integral of $2 \mathrm{OG}$ in the presence of the protein (FTO) and absence of the inhibitor; $I_{2 \mathrm{OG} \text { (blank) }}=$ integral of $2 \mathrm{OG}$ in the absence of both protein (FTO) and inhibitor; and the apparent $K_{D}\left(K_{\mathrm{D}}^{\text {app }}\right)$ of the inhibitors $(13 \mathbf{a}-\mathbf{d}, 14 \mathbf{a}-\mathbf{i})$ were calculated using reported methods. ${ }^{38}$ The $K_{\mathrm{D}}$ of $2 \mathrm{OG}$ for FTO $(1.32 \pm 0.5 \mu \mathrm{M})$ was used as a reference value.

RNA Oligonucleotide Synthesis and Purification. RNA synthesis was performed using an Applied Biosystems 394 automated DNA/RNA synthesizer on the $1.0 \mu$ mole scale using a standard phosphoramidite cycle of detritylation, coupling, capping, and oxidation. Solid supports were packed into a TWIST column (Glen Research) for synthesis.

For non-modified RNA, 2'-O-TC-protected RNA phosphoramidite monomers were used (A-bz, C-ac, G-ib and U, Sigma-Aldrich). Monomers were dissolved at $0.1 \mathrm{M}$ in anhydrous toluene/acetonitrile $(1: 1 \mathrm{v} / \mathrm{v})$ immediately prior to use. Coupling, capping, and oxidation reagents were identical to those used in standard DNA synthesis except a solution of ethylthiotetrazole (ETT) $(0.25 \mathrm{M}$ in acetonitrile, Link Technologies) was used as a coupling reagent (activator). The coupling time for all monomers during RNA synthesis was $3 \mathrm{~min}$. Stepwise coupling efficiencies were determined by the automated trityl cation conductivity measurement and in all cases were $>97 \%$. For the cleavage of the RNA from the solid support and deprotection of the bases and sugar, the solid support was exposed to dry ethylenediamine:toluene $(1: 1 \mathrm{v} / \mathrm{v})$ for $6 \mathrm{~h}$ at room temperature, washed with toluene $(3 \times 1 \mathrm{~mL})$ then acetonitrile $(3 \times 2 \mathrm{~mL})$, and dried using argon. The crude cleaved RNA was eluted with water.

For $N^{6}$-methyladenosine RNA (5-mer and 15-mer), 2'-O-TBDMS RNA phosphoramidites (A-tac, C-tac, G-tac, and $\mathrm{U}$, where tac $=$ tert- butylphenoxyacetyl; Sigma-Aldrich) were dissolved in anhydrous acetonitrile $(0.1 \mathrm{M})$ immediately prior to use. Coupling, capping, and oxidation reagents were 5-benzylthio- $1 \mathrm{H}$-tetrazole $(0.3 \mathrm{M}$ in acetonitrile; Link Technologies), fast deprotection Cap A (5\% tertbutyl phenoxyacetyl acetic anhydride in tetra-hydrofuran)/Cap B (16\% $\mathrm{N}$-methylimidazole in tetrahydrofuran), and iodine (0.1 M in tetrahydrofuran, pyridine, and water), respectively. The coupling time during RNA synthesis was $10 \mathrm{~min}$. Stepwise coupling efficiencies were determined by automated trityl cation conductivity monitoring and in all cases were $>97 \%$.

For the cleavage of the RNA from the solid support and deprotection of the bases, the solid support was exposed to concentrated aqueous ammonia:ethanol $(3: 1 \mathrm{v} / \mathrm{v})$ for $2.5 \mathrm{~h}$ at room temperature followed by $2 \mathrm{~h}$ at $55^{\circ} \mathrm{C}$ in a sealed vial. Ammonia was removed in vacuo. To remove the $2^{\prime}$-TBDMS protecting group, the ammonia-free solution was freeze-dried and re-dissolved in a 1:1 mixture of dry DMSO $(300 \mu \mathrm{L})$ and triethylaminetrihydrofluoride $(300 \mu \mathrm{L})$ and heated for $2.5 \mathrm{~h}$ at $65^{\circ} \mathrm{C}$. After cooling down to room

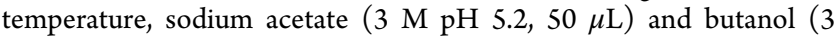
$\mathrm{mL}$ ) were added, and the RNA was stored for $30 \mathrm{~min}$ at $-80{ }^{\circ} \mathrm{C}$. RNA was then pelleted by centrifugation $\left(12,000 \mathrm{~g}, 30 \mathrm{~min}, 4{ }^{\circ} \mathrm{C}\right)$, the supernatant discarded, and the pellet washed twice with $70 \%$ ethanol $(750 \mu \mathrm{L})$. The pellet was then dried in vacuo and dissolved in water.

Oligonucleotides were purified using a Gilson HPLC system with an ACE C8 reversed-phase column $(10 \mathrm{~mm} \times 250 \mathrm{~mm}$, pore size 100 $\AA$, particle size $10 \mu \mathrm{m})$ with a gradient of buffer A (0.1 M TEAB, pH 7.5) to buffer B (0.1 M TEAB, $\mathrm{pH} 7.5$ containing 50\% v/v acetonitrile) and a flow rate of $4 \mathrm{~mL} / \mathrm{min}$. The gradient of acetonitrile in triethylammonium bicarbonate (TEAB) was increased from 0 to $50 \%$ buffer B over $30 \mathrm{~min}$. Elution was monitored by ultraviolet absorption at $298 \mathrm{~nm}$. After HPLC purification, the RNA was freezedried and then dissolved in water. Purified oligonucleotides were characterized by ESI mass spectrometry using a XEVO G2-QTOF MS instrument. Data were processed using MaxEnt and in all cases confirmed the integrity of the sequences.

Protein Crystallization. Crystals of the FTO $\Delta 31-13 \mathrm{c}$ and FTO $\Delta 31-14$ a complexes were grown in hanging drops at $293 \mathrm{~K}$ by the vapor diffusion method. For FTO $\Delta 31-13 \mathrm{c}$ crystallization, $2 \mu \mathrm{L}$ of the protein solution containing $8 \mathrm{mg} / \mathrm{mL}$ FTO $\Delta 31$ solution, $1 \mathrm{mM}$ $\mathrm{ZnSO}_{4}$, and $1 \mathrm{mM} \mathrm{13c}$ was mixed with $1 \mu \mathrm{L}$ of the reservoir solution containing $100 \mathrm{mM}$ trisodium citrate $\mathrm{pH}$ 5.6, 8\% PEG 3350, and 4\% tert-butanol to create a crystallization drop. For FTO $\Delta 31-14 a$ crystallization, $1 \mu \mathrm{L}$ of solution containing $8 \mathrm{mg} / \mathrm{mL}$ of the FTO $\Delta 31-14 \mathrm{a}$ complex and $1 \mathrm{mM}$ NADH was mixed with $1 \mu \mathrm{L}$ of reservoir solution containing $100 \mathrm{mM}$ trisodium citrate $\mathrm{pH}$ 5.6, 13.5\% PEG 3350, 4\% tert-butanol to create a crystallization drop. The drops were equilibrated with $200 \mu \mathrm{L}$ of the reservoir solution. The resultant crystals were cryoprotected by soaking crystals in the reservoir solution diluted with $20 \%(\mathrm{v} / \mathrm{v})$ glycerol before being flash cooled in liquid nitrogen.

Crystals of the AlkB $\Delta$ N11-14a complex were grown using the sitting drop method at $293 \mathrm{~K}$. The volume ratio of the protein to reservoir was 1:2. $1 \mu \mathrm{L}$ of the protein solution containing $20 \mathrm{mg} / \mathrm{mL}$ AlkB $\Delta \mathrm{N} 11,2 \mathrm{mM} \mathrm{MnCl}$, and $2 \mathrm{mM}$ of $14 a$ were mixed with $2 \mu \mathrm{L}$ of the reservoir solution containing $0.1 \mathrm{M} \mathrm{NaCl}, 21 \% \mathrm{w} / \mathrm{v}$ PEG 3350, $0.1 \mathrm{M}$ HEPES to create a crystallization drop. The resultant crystals were cryoprotected by soaking crystals in the reservoir solution diluted with $20 \%(\mathrm{v} / \mathrm{v})$ glycerol before being flash cooled in liquid nitrogen.

X-ray Data Collection, Structure Determination, and Refinement. Data were collected at Diamond Light Source beamlines I04 or I24 equipped with a Pilatus $6 \mathrm{M}-\mathrm{F}$ (FTO $\Delta 31-13 \mathrm{c}$ and AlkB $\Delta$ N11-14a) or Dectris EIGER2 9M (FTO $\Delta 31-14 a)$ detector, respectively. Data for FTO $\Delta 31-13 \mathrm{c}$ were processed inhouse using HKL $2000^{48}$ and data for FTO $\Delta 31-14 a$ and AlkB $\Delta$ N1114a were processed by the beamlines autoprocessing pipeline using the XIA2 strategy. ${ }^{49}$ FTO structures were solved by molecular replacement (MR) using PHASER ${ }^{50}$ with a structure of FTO $\Delta 31-4$ as the search model (PDB ID 4IE5), followed by iterative cycles of map fitting in $\mathrm{COOT}^{53}$ and refinement using PHENIX. ${ }^{51}$ The structure of 
AlkB $\Delta$ N11-14a was solved by MR using PHASER and PDB ID 2FDJ as the search model. Iterative cycles of model building using COOT and refinement with PHENIX were performed until the converging $R_{\text {work }}$ and $R_{\text {free }}$ no longer decreased. 14a in the FTO $\Delta 31-14$ a structure was refined with an occupancy of 0.7. Residual positive difference densities near the active site were present, likely derived from low occupancy citrate and/or glycerol from the crystallization mother liquor and cryoprotectant and could not be modeled with confidence. Data collection and refinement statistics for all structures can be found in Table S1.

Synthetic Chemistry Methods. Reagents were from SigmaAldrich, Alfa Aesar, Cambridge Biotech, Fischer Scientific, or Link Technology, unless otherwise stated. Anhydrous solvents used in reactions were either analytical grade, as obtained commercially (Alfa Aesar), or were freshly distilled. HPLC grade solvents were employed for work-up and chromatography. For the chromatographic purification of phosphoramidites, solvents were dried over $\mathrm{P}_{2} \mathrm{O}_{5}$ prior to use. Reactions involving moisture-sensitive reagents were carried out under an argon atmosphere; glassware was oven-dried and cooled under nitrogen before use. Reagents were used as supplied (analytical or HPLC grade) without prior purification. Anhydrous $\mathrm{MgSO}_{4}$ was used as a drying agent. Microwave experiments were carried out using a Biotage Initiator 8 machine. Thin-layer chromatography was performed using aluminum plates coated with 60 F254 silica. Plates were visualized using UV light $(254 \mathrm{~nm})$, or 1\% $(m / v)$ aq $\mathrm{KMnO}_{4}$ stain. Flash column chromatography was performed using Kieselgel 60 silica in a glass column, or on a Biotage SP4 flash column chromatography platform. Retention factors $\left(R_{\mathrm{f}}\right)$ are quoted to a precision of 0.05 .

Deuterated solvents were from Sigma and Apollo Scientific Ltd. ${ }^{1} \mathrm{H}$ NMR and ${ }^{13} \mathrm{C}$ NMR spectra were recorded using Bruker AVIII400, AVIII500, AVIII600, and AVIII700 NMR spectrometers. Fields were locked by external referencing to the relevant residual deuterium resonance. Chemical shifts $(\delta)$ are reported in ppm; coupling constants $(J)$ are recorded in $\mathrm{Hz}$ to the nearest $0.5 \mathrm{~Hz}$; when peak multiplicities are reported, the following abbreviations are used: $\mathrm{s}=$ singlet, $\mathrm{d}=$ doublet, $\mathrm{t}=$ triplet, $\mathrm{q}=$ quartet, $\mathrm{m}=$ multiplet, $\mathrm{br}=$ broadened, $\mathrm{dd}=$ doublet of doublets, $\mathrm{dt}=$ doublet of triplets, and $\mathrm{td}=$ triplet of doublets. Spectra were recorded at room temperature unless otherwise stated.

Low-resolution mass spectra $(\mathrm{m} / z)$ and high-resolution mass spectra (HRMS) were recorded using an LCT Premier XE (Waters, MA, USA) or a microTOF (Bruker, MA, USA).

Melting points were recorded on a Gallenkamp Hot Stage apparatus. Purity of synthesized compounds was $\geq 95 \%$ as determined by analytical reverse-phase LC/MS. IR spectra were recorded using a Bruker Tensor 27 FT-IR spectrometer as thin films. The selected characteristic peaks are reported in $\mathrm{cm}^{-1}$.

General Synthetic Procedures. General Procedure A: Synthesis of Protected Glycinate Derivatives (Suzuki Coupling) (Scheme S1). To an overnight dried microwave vial were added the requisite aryl halide (8, 9; 1 equiv), $\mathrm{K}_{3} \mathrm{PO}_{4}$ (3 equiv), and the requisite boronic acid (1.2 equiv) in $\mathrm{CH}_{3} \mathrm{CN} / \mathrm{H}_{2} \mathrm{O}$ (3:1). The vial was evacuated and filled with $\mathrm{N}_{2}$ three times. To this degassed solid mixture was added $\mathrm{Pd}\left(\mathrm{PPh}_{3}\right)_{4}(10 \mathrm{~mol} \%)$; the vial was again evacuated and filled with $\mathrm{N}_{2}$ three times. The vial was then subjected to microwave radiation (Biotage Initiator 8 machine, $135^{\circ} \mathrm{C}, 3 \mathrm{~h}$ ), $\mathrm{pH}$ was raised with $1 \mathrm{M} \mathrm{NaOH}$. The mixture was diluted with ethyl acetate and washed with $3 \times \mathrm{H}_{2} \mathrm{O}$. The combined organic extracts were dried over anhydrous $\mathrm{MgSO}_{4}$ and concentrated in vacuo. The crude mixture was chromatographed (cyclohexane/ethyl acetate 8:2 to $7: 3$ ) to provide the product.

General Procedure B: Synthesis of Protected Glycinate Derivatives (Buchwald Coupling) (Scheme S2). To an overnightdried microwave vial were added the appropriate aryl halide $(8-10 ; 1$ equiv), $\mathrm{K}_{3} \mathrm{PO}_{4}$ (3 equiv), BrettPhos (16;0.14 equiv), and $\mathrm{Pd}$ precatalyst $\left(17 ; 0.01\right.$ equiv). The vial was evacuated and filled with $\mathrm{N}_{2}$ three times. To this degassed solid mixture were added appropriate amine (1.2 equiv) and $t$ - $\mathrm{BuOH}(2.5 \mathrm{~mL})$. The vial was again evacuated and filled with $\mathrm{N}_{2}$ three times. The vial was then subjected to microwave heating (Biotage Initiator 8 machine, $8 \mathrm{~h}, 140{ }^{\circ} \mathrm{C}$ ). The solvent was removed under reduced pressure and the residue was diluted with ethyl acetate. The organic layer was washed with $3 \times$ $\mathrm{H}_{2} \mathrm{O}$ and crystallized from $\mathrm{CH}_{2} \mathrm{Cl}_{2}$. Yields varied from $22-86 \%$.

General Procedure C: Benzyl Group Deprotection (Scheme S3). To a stirred solution of the appropriate compound $(12 \mathrm{c}-\mathrm{d} ; 0.1$ $\mathrm{mmol})$ in THF $(2 \mathrm{~mL})$ was added Pd/C $(10 \mathrm{~mol} \%)$. The reaction mixture was evacuated and filled with $\mathrm{N}_{2}$ three times. The reaction mixture was stirred for $24 \mathrm{~h}$ under a $\mathrm{H}_{2}$ atmosphere. The suspension was filtered through celite pad; the filtrate was concentrated under reduced pressure. The oily residue was washed with methanol to afford the desired acid.

General Procedure D: tert-Butyl Group Deprotection (Scheme S4). To a stirred solution of compound $(11 \mathbf{a}-\mathbf{d}, 12 \mathbf{a}-\mathbf{b}, 12 \mathbf{e}-\mathbf{i}, 0.1$ $\mathrm{mmol}$ ) in THF was added excess $\mathrm{KOH}$; the reaction was stirred for 2 days at room temperature. The crude product mixture was concentrated under reduced pressure, then diluted with ethyl acetate and water. The aqueous layer was acidified with $1 \mathrm{M} \mathrm{HCl}$ to $\mathrm{pH} 3$. The resulting precipitate was filtered and washed with cold water (5 $\mathrm{mL})$.

6-Bromo-3-hydroxypicolinonitrile (6). To a suspension of 3hydroxypicolinonitrile $(1.20 \mathrm{~g}, 10 \mathrm{mmol})$ in $\mathrm{H}_{2} \mathrm{O}, \mathrm{Br}_{2}(0.6 \mathrm{~mL}, 11.5$ $\mathrm{mmol}$ ) was added portion wise over 3 days at room temperature. The mixture was washed with $10 \%$ sodium thiosulfate $(50 \mathrm{~mL})$. The product was crystallized from $\mathrm{H}_{2} \mathrm{O}$, resulting in a white solid $(670 \mathrm{mg}$, $53 \%) . \mathrm{mp} 135^{\circ} \mathrm{C} . R_{\mathrm{f}} 0.20$; IR (neat): $\nu / \mathrm{cm}^{-1} 3150$ (b, ArO-H), $2290(-\mathrm{CN}) ;{ }^{1} \mathrm{H}$ NMR $\left(400 \mathrm{MHz}, \mathrm{CD}_{3} \mathrm{CN}\right): \delta 7.37(\mathrm{~d}, J=9.0 \mathrm{~Hz}$, $1 \mathrm{H}), 7.60(\mathrm{~d}, J=9.0 \mathrm{~Hz}, 1 \mathrm{H}), 11.56(\mathrm{~s}, 1 \mathrm{H}) ;{ }^{13} \mathrm{C} \mathrm{NMR}(125 \mathrm{MHz}$, $\left.\mathrm{CD}_{3} \mathrm{CN}\right): \delta 127.5(\mathrm{ArC}), 128.2(\mathrm{ArC}), 130.4(\mathrm{ArC}), 132.9(\mathrm{ArC})$, 142.5 (ArC), 156.6 (CN); HRMS (ESI) $m / z$ : calcd for $\mathrm{C}_{6} \mathrm{H}_{2}{ }^{79} \mathrm{BrN}_{2} \mathrm{O}$ $[\mathrm{M}-\mathrm{H}]^{-}, 196.9356$; observed, 196.9350 .

6-Bromo-3-hydroxypicolinic Acid (7). To a stirred suspension of 6-bromo-3-hydroxypicolinonitrile $(6 ; 2.8 \mathrm{~g}, 14.1 \mathrm{mmol})$ in methanol $(50 \mathrm{~mL}), 30 \% \mathrm{w} / \mathrm{v} \mathrm{NaOH}(44 \mathrm{~mL}, 51.8 \mathrm{mmol})$ was added. The reaction mixture was heated at reflux for $12 \mathrm{~h}$. The solvent was removed under reduced pressure and the suspension was acidified with concentrated $\mathrm{HCl}$ to $\mathrm{pH} 2$. The resulting precipitate was filtered and washed with cold water $(5 \mathrm{~mL})$. Filtration afforded product 7 $(3.1 \mathrm{~g}, 100 \%)$ as white needles. $\mathrm{mp} 122-124{ }^{\circ} \mathrm{C}$. IR (neat): $\nu / \mathrm{cm}^{-1}$ $3100(\mathrm{ArO}-\mathrm{H}), 2850(\mathrm{COO}-\mathrm{H}), 1716(\mathrm{HOC}=\mathrm{O}) ;{ }^{1} \mathrm{H}$ NMR $(400$ MHz, DMSO- $\left.d_{6}\right): \delta 7.05-7.10(\mathrm{~m}, 1 \mathrm{H}), 7.33-7.75(\mathrm{~m}, 1 \mathrm{H}), 11.43$ $(\mathrm{s}, 1 \mathrm{H}) ;{ }^{13} \mathrm{C}$ NMR (125 MHz, DMSO- $\left.d_{6}\right) 131.2(\mathrm{ArC}), 133.7$ (ArC), 135.8 (ArC), 137.9 ( $\mathrm{ArC}), 143.3(\mathrm{ArC}), 169.1(\mathrm{C}=\mathrm{O})$; HRMS (ESI) $m / z$ : calcd for $\mathrm{C}_{6} \mathrm{H}_{3}{ }^{79} \mathrm{BrNO}_{3}[\mathrm{M}-\mathrm{H}]^{-}, 215.9302$; observed, 215.9298 .

tert-Butyl (6-Bromo-3-hydroxypicolinoyl)glycinate (8). To a mixture of 6-bromo-3-hydroxypicolinic acid $(7 ; 0.2 \mathrm{~g}, 0.92 \mathrm{mmol})$, diisopropylethylamine $(0.5 \mathrm{~mL}, 2.75 \mathrm{mmol})$, and propylphosphonic anhydride solution (T3P, $0.70 \mathrm{~mL}, 1.2 \mathrm{mmol}$ ) in ethyl acetate $(2 \mathrm{~mL})$ was added glycine tert-butyl ester hydrochloride $(0.2 \mathrm{~g}, 1.2 \mathrm{mmol})$. The reaction was subjected to microwave irradiation at $120^{\circ} \mathrm{C}$ for 4 h. The mixture was diluted with ethyl acetate and washed with water $(3 \times 10 \mathrm{~mL})$ and concentrated in vacuo. The residue was purified by column chromatography (9:1 to 6:4 cyclohexane/ethyl acetate) to give a pale yellow solid $(0.13 \mathrm{~g}, 42 \%)$. mp $105-106{ }^{\circ} \mathrm{C} . R_{\mathrm{f}} 0.40$; IR (neat): $\nu / \mathrm{cm}^{-1} 3349(\mathrm{NH}), 1748(t-\mathrm{BuOC}=\mathrm{O}), 1675(\mathrm{NHC}=\mathrm{O})$; ${ }^{1} \mathrm{H}$ NMR $\left(500 \mathrm{MHz}, \mathrm{CDCl}_{3}\right): \delta 1.44(\mathrm{~s}, 9 \mathrm{H}), 4.04(\mathrm{~d}, J=5.5 \mathrm{~Hz}$, $2 \mathrm{H}), 7.13(\mathrm{~d}, J=9.0 \mathrm{~Hz}, 1 \mathrm{H}), 7.40(\mathrm{~d}, J=9.0 \mathrm{~Hz}, 1 \mathrm{H}), 8.10(\mathrm{br} \mathrm{s}$, $1 \mathrm{H}), 11.83(\mathrm{~s}, 1 \mathrm{H}) ;{ }^{13} \mathrm{C}$ NMR $\left(125 \mathrm{MHz}, \mathrm{CDCl}_{3}\right): \delta 28.0(\mathrm{C}-$ $\left.\left(\mathrm{CH}_{3}\right)_{3}\right), 41.5\left(\mathrm{CH}_{2}\right), 82.7\left(\mathrm{C}\left(\mathrm{CH}_{3}\right)_{3}\right), 129.0(\mathrm{ArC}), 129.4(\mathrm{ArC})$, 131.3 (ArC), $133.2(\operatorname{ArC}), 157.3(\operatorname{ArC}), 167.7(\mathrm{C}=\mathrm{O}), 168.0(\mathrm{C}=$ O); HRMS (ESI) $m / z$ : calcd for $\mathrm{C}_{12} \mathrm{H}_{15}{ }^{79} \mathrm{BrN}_{2} \mathrm{NaO}_{4}[\mathrm{M}+\mathrm{Na}]^{+}$, 353.0107; observed, 353.0095.

Benzyl-(6-bromo-3-hydroxypicolinoyl)glycinate (9). To a mixture of 6-bromo-3-hydroxypicolinic acid (7; $0.20 \mathrm{~g}, 0.92 \mathrm{mmol})$, DIPEA $(0.5 \mathrm{~mL}, 2.75 \mathrm{mmol})$, and T3P $(0.7 \mathrm{~mL}, 1.19 \mathrm{mmol})$ in ethyl acetate $(2 \mathrm{~mL})$ was added glycine tert-butyl ester hydrochloride $(0.2 \mathrm{~g}, 1.20$ $\mathrm{mmol})$. The reaction was subjected to microwave irradiation $\left(120^{\circ} \mathrm{C}\right.$, $4 \mathrm{~h})$. The mixture was diluted with ethyl acetate and washed with water $(3 \times 10 \mathrm{~mL})$. The organic extracts were combined, dried over 
$\mathrm{MgSO}_{4}$, and then concentrated in vacuo. Chromatography (cyclohexane/ethyl acetate $9: 1$ to $6: 4)$ afforded the product $(0.13 \mathrm{~g}, 42 \%)$ as a pale yellow solid. $\mathrm{mp} 102-104{ }^{\circ} \mathrm{C} . R_{\mathrm{f}} 0.45$; IR (neat): $\nu / \mathrm{cm}^{-1} 3391$ (Ar-OH), $3035(\mathrm{~N}-\mathrm{H}), 2949(\mathrm{COO}-\mathrm{H}), 1741(\mathrm{PhOC}=\mathrm{O}), 1654$ $(\mathrm{NHC}=\mathrm{O}) ;{ }^{1} \mathrm{H}$ NMR $\left(400 \mathrm{MHz}, \mathrm{CDCl}_{3}\right): \delta 4.19(\mathrm{~d}, J=6.0 \mathrm{~Hz}$, $2 \mathrm{H}), 5.17(\mathrm{~s}, 2 \mathrm{H}), 7.15(\mathrm{~d}, J=9.0 \mathrm{~Hz}, 1 \mathrm{H}), 7.19(\mathrm{~s}, 2 \mathrm{H}), 7.31(\mathrm{~m}$, $4 \mathrm{H}), 8.12$ (br s, $1 \mathrm{H}), 11.72(\mathrm{~s}, 1 \mathrm{H}) ;{ }^{13} \mathrm{C}$ NMR $\left(101 \mathrm{MHz}, \mathrm{CDCl}_{3}\right): \delta$ $40.9\left(\mathrm{CH}_{2}\right), 67.5\left(\mathrm{CH}_{2}\right), 128.5(\mathrm{ArC}), 128.7(\mathrm{ArC}), 128.7(\mathrm{ArC})$, 129.1 (ArC), 129.5 (ArC), 131.2 (ArC), 133.5 (ArC), 135.0 (ArC), $157.4(\mathrm{ArC}), 168.0(\mathrm{C}=\mathrm{O}), 168.8(\mathrm{C}=\mathrm{O})$; HRMS $(\mathrm{ESI}) \mathrm{m} / z$ : calcd for $\mathrm{C}_{15} \mathrm{H}_{12}{ }^{79} \mathrm{BrN}_{2} \mathrm{O}_{4}[\mathrm{M}-\mathrm{H}]^{-}$, 362.9996; observed, 362.9981.

Methyl (6-Bromo-3-hydroxypicolinoyl)glycinate (10). To a mixture of 6-bromo-3-hydroxypicolinic acid (7;0.2 g, $0.92 \mathrm{mmol})$, diisopropylethylamine $(0.5 \mathrm{~mL}, 2.75 \mathrm{mmol})$, and propylphosphonic anhydride solution (T3P, $0.70 \mathrm{~mL}, 1.2 \mathrm{mmol})$ in ethyl acetate $(2 \mathrm{~mL})$ was added glycine methyl ester hydrochloride $(0.3 \mathrm{~g}, 1.2 \mathrm{mmol})$. The reaction mixture was subjected to microwave irradiation at $120^{\circ} \mathrm{C}$ for $4 \mathrm{~h}$. The mixture was diluted with ethyl acetate, washed with water (3 $\times 10 \mathrm{~mL}$ ), and concentrated in vacuo. The residue was purified by column chromatography (7:3 to 5:5 cyclohexane/ethyl acetate) to give $10(114 \mathrm{mg}, 43 \%)$ as white crystals, $\mathrm{mp} 88-89{ }^{\circ} \mathrm{C} . R_{\mathrm{f}} 0.36$; IR (neat): $\nu / \mathrm{cm}^{-1} 3355(\mathrm{O}-\mathrm{H}, \mathrm{N}-\mathrm{H}), 1749(\mathrm{MeOC}=\mathrm{O}), 1651$ $(\mathrm{NHC}=\mathrm{O}) ;{ }^{1} \mathrm{H}$ NMR $\left(500 \mathrm{MHz}, \mathrm{CDCl}_{3}\right): \delta 3.79(\mathrm{~s}, 3 \mathrm{H}), 4.23(\mathrm{~d}, J$ $=6.0 \mathrm{~Hz}, 2 \mathrm{H}), 7.28(\mathrm{~d}, J=9.0 \mathrm{~Hz}, 1 \mathrm{H}), 8.07(\mathrm{~d}, J=9.0 \mathrm{~Hz}, 1 \mathrm{H}), 8.46$ (s, 1H), $11.76(\mathrm{~s}, 1 \mathrm{H}) ;{ }^{13} \mathrm{C} \mathrm{NMR}\left(125 \mathrm{MHz}, \mathrm{CDCl}_{3}\right): \delta 40.7\left(\mathrm{CH}_{2}\right)$, $52.5\left(\mathrm{CH}_{3}\right), 126.1(\mathrm{ArC}), 128.9(\mathrm{ArC}), 131.0(\mathrm{ArC}), 139.8(\mathrm{ArC})$, 157.7 (ArC), $169.0(\mathrm{C}=\mathrm{O}), 169.6(\mathrm{C}=\mathrm{O})$; HRMS (ESI+) calcd for $\mathrm{C}_{9} \mathrm{H}_{9}{ }_{9}{ }^{79} \mathrm{BrN}_{2} \mathrm{NaO}_{4}[\mathrm{M}+\mathrm{Na}]^{+}, 310.9635$; observed, 310.9623 .

tert-Butyl-N-((3-hydroxy-6-phenylpyridin-2-yl)carbonyl)glycinate (11a). Following general procedure A; $8(0.20 \mathrm{~g}, 0.6 \mathrm{mmol})$ was reacted with phenylboronic acid $(88 \mathrm{mg}, 0.73 \mathrm{mmol}), \mathrm{K}_{2} \mathrm{CO}_{3}$ $(0.25 \mathrm{~g}, 1.18 \mathrm{mmol})$ in $\mathrm{CH}_{3} \mathrm{CN} / \mathrm{H}_{2} \mathrm{O}(4 \mathrm{~mL})$ with $\mathrm{Pd}\left(\mathrm{PPh}_{3}\right)_{4}(70$ $\mathrm{mg}, 0.06 \mathrm{mmol})$. Chromatography afforded compound $11 \mathrm{a}(35 \mathrm{mg}$, $21 \%)$ as colorless oil. IR (neat): $\nu / \mathrm{cm}^{-1} 3400(\mathrm{~N}-\mathrm{H}), 3090(\mathrm{C}-\mathrm{H})$, $1737(t \mathrm{BuOC}=\mathrm{O}), 1652(\mathrm{NHC}=\mathrm{O}) ;{ }^{1} \mathrm{H}$ NMR $(400 \mathrm{MHz}$, $\left.\mathrm{CDCl}_{3}\right): \delta 1.56(\mathrm{~s}, 9 \mathrm{H}), 4.19(\mathrm{~d}, J=5.5 \mathrm{~Hz}, 2 \mathrm{H}), 7.45-7.40(\mathrm{~m}$, $2 \mathrm{H}), 7.52-7.47(\mathrm{~m}, 2 \mathrm{H}), 7.84(\mathrm{~d}, J=9.0 \mathrm{~Hz}, 1 \mathrm{H}), 7.97-7.94(\mathrm{~m}$, $2 \mathrm{H}), 8.59(\mathrm{t}, J=5.0 \mathrm{~Hz}, 1 \mathrm{H}), 11.95(\mathrm{~s}, 1 \mathrm{H}) ;{ }^{13} \mathrm{C}$ NMR $(101 \mathrm{MHz}$, $\left.\mathrm{CDCl}_{3}\right): \delta 28.1\left(\mathrm{C}\left(\mathrm{CH}_{3}\right)_{3}\right), 41.6\left(\mathrm{CH}_{2}\right), 82.6\left(\mathrm{C}_{\left.\left(\mathrm{CH}_{3}\right)_{3}\right), 126.0}\right.$ $(\mathrm{ArC}), 126.3(\mathrm{ArC}), 127.1(\mathrm{ArC}), 128.6(2 \mathrm{ArC}), 128.8(2 \mathrm{ArC})$, 130.3 (ArC), 138.1 (ArC), 147.7 ( $\mathrm{ArC}), 156.9(\mathrm{ArC}), 160.9(\mathrm{C}=\mathrm{O})$, $168.2\left(\mathrm{C}=\mathrm{O}\right.$ ); HRMS (ESI) $\mathrm{m} / z$ : calcd for $\mathrm{C}_{18} \mathrm{H}_{20} \mathrm{~N}_{2} \mathrm{NaO}_{4}[\mathrm{M}+$ $\mathrm{Na}]^{+}, 351.1321$; observed, 351.1315.

tert-Butyl N-((6-(biphenyl-2-yl)-3-hydroxypyridin-2-yl)carbonyl)glycinate $(11 b)$. Following general procedure $A ; 8(0.20 \mathrm{~g}, 0.60$ $\mathrm{mmol})$ was reacted with (1,1'-biphenyl)-2-ylboronic acid $(0.10 \mathrm{~g}, 0.72$ $\mathrm{mmol}), \mathrm{K}_{2} \mathrm{CO}_{3}(0.25 \mathrm{~g}, 1.18 \mathrm{mmol})$ in $\mathrm{CH}_{3} \mathrm{CN} / \mathrm{H}_{2} \mathrm{O}(4 \mathrm{~mL})$ with $\mathrm{Pd}\left(\mathrm{PPh}_{3}\right)_{4} \quad(70 \mathrm{mg}, 0.0604 \mathrm{mmol})$. Chromatography afforded compound 11b $(66 \mathrm{mg}, 27 \%)$ as yellow oil. IR (neat): $\nu / \mathrm{cm}^{-1}$ $3400(\mathrm{~N}-\mathrm{H}), 2978(\mathrm{Ar} \mathrm{C}-\mathrm{H}), 1743(\mathrm{tBuOC}=\mathrm{O}), 1653(\mathrm{NHC}=$ O) ${ }^{1} \mathrm{H}$ NMR $\left(400 \mathrm{MHz}, \mathrm{CDCl}_{3}\right): \delta 1.55(\mathrm{~s}, 9 \mathrm{H}), 4.07(\mathrm{~d}, J=6.0 \mathrm{~Hz}$, $2 \mathrm{H}), 7.22-7.12(\mathrm{~m}, 3 \mathrm{H}), 7.38-7.26(\mathrm{~m}, 4 \mathrm{H}), 7.49-7.46(\mathrm{~m}, 3 \mathrm{H})$, $7.73-7.69(\mathrm{~m}, 1 \mathrm{H}), 8.18(\mathrm{t}, J=6.0 \mathrm{~Hz}, 1 \mathrm{H}), 11.89(\mathrm{~s}, 1 \mathrm{H}) ;{ }^{13} \mathrm{C} \mathrm{NMR}$ $\left(101 \mathrm{MHz}, \mathrm{CDCl}_{3}\right): \delta 28.1\left(\mathrm{C}\left(\mathrm{CH}_{3}\right)_{3}\right), 41.5\left(\mathrm{CH}_{2}\right), 82.5\left(\mathrm{C}\left(\mathrm{CH}_{3}\right)_{3}\right)$, 126.8 (ArC), 127.7 ( $\mathrm{ArC}), 128.2(\mathrm{ArC}), 128.5(\mathrm{ArC}), 128.8(\mathrm{ArC})$, 129.5 (ArC), 130.2 (ArC), 130.2 (ArC), 130.8 (ArC), 130.7 (ArC), 133.8 (ArC), 137.1 (ArC), 140.8 (ArC), 141.6 (ArC), 148.1 (ArC), $156.2(\operatorname{ArC}), 160.1(\mathrm{C}=\mathrm{O}), 167.6(\mathrm{ArC}), 168.1(\mathrm{ArC}), 168.7(\mathrm{C}=$ O); HRMS (ESI) $m / z$ : calcd for $\mathrm{C}_{24} \mathrm{H}_{24} \mathrm{~N}_{2} \mathrm{NaO}_{4}[\mathrm{M}+\mathrm{Na}]^{+}$, 427.1634; observed, 427.1628.

tert-Butyl N-((3-Hydroxy-6-(naphthalen-1-yl)pyridin-2-yl)carbonyl)glycinate (11c). Following general procedure A; 8 (0.20 $\mathrm{g}, 0.60 \mathrm{mmol})$ was reacted with naphthalen-1-ylboronic acid $(0.13 \mathrm{~g}$, $0.72 \mathrm{mmol}), \mathrm{K}_{2} \mathrm{CO}_{3}(0.25 \mathrm{~g}, 1.2 \mathrm{mmol})$ in $\mathrm{CH}_{3} \mathrm{CN} / \mathrm{H}_{2} \mathrm{O}(4 \mathrm{~mL})$ with $\mathrm{Pd}(\mathrm{PPh} 3)_{4} \quad(70 \mathrm{mg}, 0.06 \mathrm{mmol})$. Chromatography afforded compound 11c (61 mg, 27\%) as yellow oil. IR (neat): $\nu / \mathrm{cm}^{-1}$ $3400(\mathrm{~N}-\mathrm{H}), 2978(\mathrm{C}-\mathrm{H}), 1740(\mathrm{tBuOC}=\mathrm{O}), 1652(\mathrm{NHC}=\mathrm{O})$; ${ }^{1} \mathrm{H}$ NMR $\left(400 \mathrm{MHz}, \mathrm{CDCl}_{3}\right): \delta 1.52(\mathrm{~s}, 9 \mathrm{H}), 4.14(\mathrm{~d}, J=6.0 \mathrm{~Hz}$, $2 \mathrm{H}), 7.49(\mathrm{~d}, J=8.5 \mathrm{~Hz}, 1 \mathrm{H}), 7.60-7.50(\mathrm{~m}, 4 \mathrm{H}), 7.67(\mathrm{~d}, J=8.5$ $\mathrm{Hz}, 1 \mathrm{H}), 7.96-7.93(\mathrm{~m}, 2 \mathrm{H}), 8.09-8.06(\mathrm{~m}, 1 \mathrm{H}), 8.42(\mathrm{t}, J=6.0 \mathrm{~Hz}$,
$1 \mathrm{H}), 12.03(\mathrm{~s}, 1 \mathrm{H}) ;{ }^{13} \mathrm{C}$ NMR $\left(101 \mathrm{MHz}, \mathrm{CDCl}_{3}\right): \delta 28.0$ $\left(\mathrm{C}\left(\mathrm{CH}_{3}\right)_{3}\right), 41.5\left(\mathrm{CH}_{2}\right), 82.5\left(\mathrm{C}\left(\mathrm{CH}_{3}\right)_{3}\right), 125.3(\mathrm{ArC}), 125.4$ ( $\mathrm{ArC}), 125.9(\mathrm{ArC}), 126.6(\mathrm{ArC}), 126.6,(\mathrm{ArC}), 127.4(\mathrm{ArC})$, 128.5 (ArC), 128.9 (ArC), 130.4 (ArC), 130.5 (ArC), 131.5 (ArC), 133.9 (ArC), 137.3 (ArC), 149.2 (ArC), 156.7 (ArC), $168.1(\mathrm{C}=\mathrm{O})$, $169.1\left(\mathrm{C}=\mathrm{O}\right.$ ); HRMS (ESI) $\mathrm{m} / z$ : calcd for $\mathrm{C}_{22} \mathrm{H}_{22} \mathrm{~N}_{2} \mathrm{NaO}_{4}[\mathrm{M}+$ $\mathrm{Na}]^{+}, 401.1472$; observed, 401.1462.

tert-Butyl N-((3-Hydroxy-6-(quinolin-5-yl)pyridin-2-yl)carbonyl)glycinate (11d). Following general procedure A; 8 (0.25 g, 0.76 $\mathrm{mmol}$ ) was reacted with quinolin-5-ylboronic acid (0.16 g, 0.91 $\mathrm{mmol}), \mathrm{K}_{2} \mathrm{CO}_{3}(0.31 \mathrm{~g}, 2.3 \mathrm{mmol})$ in $\mathrm{CH}_{3} \mathrm{CN} / \mathrm{H}_{2} \mathrm{O}(4 \mathrm{~mL})$ with $\mathrm{Pd}\left(\mathrm{PPh}_{3}\right)_{4} \quad(87 \mathrm{mg}, 0.07 \mathrm{mmol})$. Chromatography afforded compound 11d (70 mg, 24\%) as a white solid. $\mathrm{mp} 197-200{ }^{\circ} \mathrm{C}$. IR (neat): $\nu / \mathrm{cm}^{-1} 3200(\mathrm{~N}-\mathrm{H}), 1749(t \mathrm{BuOC}=\mathrm{O}), 1646(\mathrm{NHC}=$ $\mathrm{O}) ;{ }^{1} \mathrm{H}$ NMR $\left(400 \mathrm{MHz}, \mathrm{CDCl}_{3}\right): \delta 1.46(\mathrm{~s}, 9 \mathrm{H}), 4.12(\mathrm{~d}, J=6.0 \mathrm{~Hz}$, $2 \mathrm{H}), 7.40(\mathrm{dd}, J=8.5,4.0 \mathrm{~Hz}, 1 \mathrm{H}), 7.52-7.56(\mathrm{~m}, 1 \mathrm{H}), 7.64-7.68$ $(\mathrm{m}, 2 \mathrm{H}), 7.74-7.78(\mathrm{~m}, 1 \mathrm{H}), 8.16(\mathrm{~d}, J=8.5 \mathrm{~Hz}, 1 \mathrm{H}), 8.51-8.47(\mathrm{~m}$, $2 \mathrm{H}), 8.94-8.89(\mathrm{~m}, 1 \mathrm{H}), 12.05(\mathrm{~s}, 1 \mathrm{H}) ;{ }^{13} \mathrm{C} \mathrm{NMR}(101 \mathrm{MHz}$, $\left.\mathrm{CDCl}_{3}\right): \delta 28.0\left(\mathrm{C}\left(\mathrm{CH}_{3}\right)_{3}\right), 41.4\left(\mathrm{CH}_{2}\right), 82.6\left(\mathrm{C}_{\left.\left(\mathrm{CH}_{3}\right)_{3}\right), 121.5}\right.$ ( $\mathrm{ArC}), 127.1$ ( $\mathrm{ArC}), 127.6(\mathrm{ArC}), 128.8(\mathrm{ArC}), 130.2(\mathrm{ArC}), 130.3$ (ArC), 132.9 (ArC), 134.1 (2ArC), 137.35 ( $\mathrm{ArC}), 147.9$ (ArC), 148.5 ( $\mathrm{ArC}$ ), $150.4(\mathrm{ArC}), 157.0(\mathrm{ArC}), 168.1(\mathrm{C}=\mathrm{O}), 168.9(\mathrm{C}=$ $\mathrm{O})$; HRMS (ESI) $m / z$ : calcd for $\mathrm{C}_{21} \mathrm{H}_{22} \mathrm{~N}_{3} \mathrm{O}_{4}[\mathrm{M}+\mathrm{H}]^{+}, 380.1605$; observed, 380.1603.

tert-Butyl N-((3-Hydroxy-6-phenylpyridin-2-yl)carbonyl)glycinate (13a). 11a (200 mg, $0.6 \mathrm{mmol})$ was reacted according to general procedure $\mathrm{D}$; concentration in vacuo afforded compound 13a (50 mg, 30\%) as a white solid. mp $141-145{ }^{\circ} \mathrm{C}$. IR (neat): $\nu / \mathrm{cm}^{-1}$ $3400(\mathrm{O}-\mathrm{H}), 3200(\mathrm{~N}-\mathrm{H}), 3070(\mathrm{C}-\mathrm{H}), 1708(\mathrm{HOC}=\mathrm{O}), 1652$ $(\mathrm{NHC}=\mathrm{O}) ;{ }^{1} \mathrm{H}$ NMR $\left(400 \mathrm{MHz}, \mathrm{DMSO}-d_{6}\right): \delta 4.07(\mathrm{~d}, J=6.0 \mathrm{~Hz}$, $2 \mathrm{H}), 7.46-7.41(\mathrm{~m}, 1 \mathrm{H}), 7.59-7.54(\mathrm{~m}, 3 \mathrm{H}), 8.18(\mathrm{~d}, J=9.0 \mathrm{~Hz}$, $1 \mathrm{H}), 8.25-8.23(\mathrm{~m}, 2 \mathrm{H}), 9.48(\mathrm{t}, J=6.0 \mathrm{~Hz}, 1 \mathrm{H}), 12.38(\mathrm{~s}, 1 \mathrm{H}) ;{ }^{13} \mathrm{C}$ NMR $\left(101 \mathrm{MHz}, \mathrm{DMSO}-d_{6}\right): \delta 41.2\left(\mathrm{CH}_{2}\right), 126.3(\mathrm{ArC}), 126.7$ (ArC), 127.5 (ArC), 127.8 (ArC), 129.1 (ArC), 129.2 (ArC), 130.5 ( $\mathrm{ArC}), 134.5$ ( $\mathrm{ArC}), 137.7(\mathrm{ArC}), 147.0(\mathrm{ArC}), 156.9(\mathrm{ArC}), 169.5$ $(\mathbf{C}=\mathrm{O}), 171.1(\mathbf{C}=\mathrm{O})$; HRMS (ESI) $\mathrm{m} / z$ : calcd for $\mathrm{C}_{14} \mathrm{H}_{11} \mathrm{~N}_{2} \mathrm{O}_{4}$ $[\mathrm{M}-\mathrm{H}]^{-}$, 271.0719; observed, 271.0719.

N-((6-(Biphenyl-2-yl)-3-hydroxypyridin-2-yl)carbonyl)glycine (13b). Following general procedure D; concentration in vacuo afforded compound $13 \mathrm{~b}(16 \mathrm{mg}, 8 \%)$ as off white oil. IR (neat): $\nu /$ $\mathrm{cm}^{-1} 3402(\mathrm{~N}-\mathrm{H}), 2913(\mathrm{Ar} \mathrm{C}-\mathrm{H}), 1750(\mathrm{HOC}=\mathrm{O}), 1657$ $(\mathrm{HNC}=\mathrm{O}) ;{ }^{1} \mathrm{H}$ NMR $\left(400 \mathrm{MHz}, \mathrm{DMSO}-d_{6}\right): \delta 4.09(\mathrm{~s}, 2 \mathrm{H}), 7.09-$ $7.15(\mathrm{~m}, 4 \mathrm{H}), 7.24-7.30(\mathrm{~m}, 3 \mathrm{H}), 7.40-7.43(\mathrm{~m}, 1 \mathrm{H}), 7.45-7.49$ $(\mathrm{m}, 2 \mathrm{H}), 7.71(\mathrm{dd}, J=6.0,3.0 \mathrm{~Hz}, 1 \mathrm{H}) ;{ }^{13} \mathrm{C}$ NMR $(101 \mathrm{MHz}$, DMSO-d $\left.d_{6}\right): \delta 39.9\left(\mathrm{CH}_{2}\right), 125.3(\mathrm{ArC}), 126.4(\mathrm{ArC}), 127.3(\mathrm{ArC})$, 127.9 (ArC), $128.2(\mathrm{ArC}), 128.6(\mathrm{ArC}), 129.2(\mathrm{ArC}), 129.9(\mathrm{ArC})$, 130.0 (ArC), 130.2 (ArC), 131.7 (ArC), $132.4(\operatorname{ArC}), 138.0(\operatorname{ArC})$, 140.9 (ArC), $141.8(\operatorname{ArC}), 149.5(\operatorname{ArC}), 155.9(\operatorname{ArC}), 169.2(\mathrm{C}=\mathrm{O})$, $171.1(\mathrm{C}=\mathrm{O})$; HRMS (ESI) $m / z$ : calcd for $\mathrm{C}_{20} \mathrm{H}_{15} \mathrm{~N}_{2} \mathrm{O}_{4}[\mathrm{M}-\mathrm{H}]^{-}$, 347.1037; observed, 347.1023.

$N-((3-H y d r o x y-6-($ naphthalen-1-yl)pyridin-2-yl)carbonyl)glycine (13c). 11c $(200 \mathrm{mg}, 0.6 \mathrm{mmol})$ was reacted according to general procedure $\mathrm{D}$; concentration in vacuo afforded compound $13 \mathrm{c}(67 \mathrm{mg}$, $34 \%)$ as a white solid. $\mathrm{mp} 179-182{ }^{\circ} \mathrm{C}$. IR (neat): $\nu / \mathrm{cm}^{-1} 3361(\mathrm{O}-$ $\mathrm{H}), 3200(\mathrm{~N}-\mathrm{H}), 1749(\mathrm{HOC}=\mathrm{O}), 1658(\mathrm{NHC}=\mathrm{O}) ;{ }^{1} \mathrm{H}$ NMR $\left(400 \mathrm{MHz}\right.$, DMSO- $\left.d_{6}\right): \delta 4.02(\mathrm{~d}, J=6.0 \mathrm{~Hz}, 2 \mathrm{H}), 7.67-7.54(\mathrm{~m}$, $5 \mathrm{H}), 7.80(\mathrm{~d}, J=8.5 \mathrm{~Hz}, 1 \mathrm{H}), 7.96-7.94(\mathrm{~m}, 1 \mathrm{H}), 8.04(\mathrm{dd}, J=8.0$, $1.0 \mathrm{~Hz}, 2 \mathrm{H}), 9.17(\mathrm{t}, J=6.0 \mathrm{~Hz}, 1 \mathrm{H}), 12.44(\mathrm{~s}, 1 \mathrm{H}) ;{ }^{13} \mathrm{C}$ NMR $(101$ MHz, DMSO- $\left.d_{6}\right): \delta 41.2\left(\mathrm{CH}_{2}\right), 121.15(\mathrm{ArC}), 125.6(\mathrm{ArC}), 125.85$ (ArC), 126.5 (ArC), 127.1 (ArC), 127.2 (ArC), 127.95 (ArC), 128.8 (ArC), 129.1 (ArC), 130.8 (ArC), 131.1 (ArC), $133.8(\operatorname{ArC}), 137.5$ ( $\mathrm{ArC}), 149.2(\mathrm{ArC}), 156.7(\mathrm{ArC}), 169.4(\mathrm{C}=\mathrm{O}), 170.9(\mathrm{C}=\mathrm{O})$; HRMS (ESI) $m / z$ : calcd for $\mathrm{C}_{18} \mathrm{H}_{13} \mathrm{~N}_{2} \mathrm{O}_{4}[\mathrm{M}-\mathrm{H}]^{-}, 321.0881$; observed, 321.0877.

$N-((3-H y d r o x y-6-(q u i n o l i n-5-y l) p y r i d i n-2-y l)$ carbonyl)glycine (13d). Following general procedure $\mathrm{D}$; concentration in vacuo afforded compound 13d (114 mg, 47\%) as off white oil. IR (neat): $\nu / \mathrm{cm}^{-1} 3376(\mathrm{~N}-\mathrm{H}), 1730(\mathrm{HOC}=\mathrm{O}), 1654(\mathrm{NHC}=\mathrm{O}) ;{ }^{1} \mathrm{H}$ NMR $\left(400 \mathrm{MHz}\right.$, DMSO- $\left.d_{6}\right): \delta 4.00(\mathrm{~d}, J=6.0 \mathrm{~Hz}, 2 \mathrm{H}), 7.54(\mathrm{dd}, J$ $=8.5,4.0 \mathrm{~Hz}, 1 \mathrm{H}), 7.63(\mathrm{dd}, J=8.5,2.0 \mathrm{~Hz}, 1 \mathrm{H}), 7.78(\mathrm{dd}, J=7.0$, 
$1.0 \mathrm{~Hz}, 1 \mathrm{H}), 7.90-7.84(\mathrm{~m}, 2 \mathrm{H}), 8.13-8.11(\mathrm{~m}, 1 \mathrm{H}), 8.43$ (ddd, $J=$ $8.5,1.5,1.0 \mathrm{~Hz}, 1 \mathrm{H}), 8.95(\mathrm{dd}, J=4.0,1.5 \mathrm{~Hz}, 1 \mathrm{H}), 9.20(\mathrm{t}, J=6.0$ $\mathrm{Hz}, 1 \mathrm{H}), 12.45(\mathrm{~s}, 1 \mathrm{H}) ;{ }^{13} \mathrm{C}$ NMR $\left(101 \mathrm{MHz}, \mathrm{DMSO}-d_{6}\right): \delta 41.9$ $\left(\mathrm{CH}_{2}\right), 122.5$ ( $\left.\mathrm{ArC}\right), 126.3(\mathrm{ArC}), 127.5(\mathrm{ArC}), 128.2(\mathrm{ArC}), 130.1$ (ArC), 130.8 (ArC), 131.2 (ArC), 134.3 (ArC), 137.8 (ArC), 148.0 (ArC), 148.3 (ArC), 151.0 (ArC), 156.9 (ArC), $169.40(\operatorname{ArC}), 171.0$ $(\mathbf{C}=\mathrm{O}), 172.6(\mathbf{C}=\mathrm{O})$; HRMS (ESI) $\mathrm{m} / z$ : calcd for $\mathrm{C}_{17} \mathrm{H}_{12} \mathrm{~N}_{3} \mathrm{O}_{4}$ $[\mathrm{M}-\mathrm{H}]^{-}$, 322.0833; observed, 322.0828 .

tert-Butyl (3-Hydroxy-6-((4-nitrophenyl)amino)picolinoyl)glycinate $(12 a)$. The desired product was prepared according to general procedure B; the use of aryl derivative $8(40 \mathrm{mg}, 0.12 \mathrm{mmol})$ and 4-nitroaniline (18 $\mathrm{mg}, 0.13 \mathrm{mmol}$ ) afforded 12a (40 mg, 86\%) as a yellow solid. mp $196-200{ }^{\circ} \mathrm{C}$. IR (neat): $\nu / \mathrm{cm}^{-1} 3400(\mathrm{~N}-\mathrm{H})$, $3367(\mathrm{ArO}-\mathrm{H}), 1741(t-\mathrm{BuC}=\mathrm{O}), 1645(\mathrm{NHC}=\mathrm{O}), 1502,1319$ $(\mathrm{N}-\mathrm{O}) ;{ }^{1} \mathrm{H}$ NMR $\left(400 \mathrm{MHz}, \mathrm{CDCl}_{3}\right): \delta 1.56(\mathrm{~s}, 9 \mathrm{H}), 4.15(\mathrm{~d}, J=$ $5.0 \mathrm{~Hz}, 2 \mathrm{H}), 6.82(\mathrm{br} \mathrm{s}, 1 \mathrm{H}), 7.07(\mathrm{~d}, J=9.0 \mathrm{~Hz}, 1 \mathrm{H}), 7.36(\mathrm{~d}, J=9.0$ $\mathrm{Hz}, 1 \mathrm{H}), 7.45(\mathrm{~d}, J=1.0 \mathrm{~Hz}, 2 \mathrm{H}), 8.18($ br s, $1 \mathrm{H}), 8.24(\mathrm{~d}, J=1.0 \mathrm{~Hz}$, $2 \mathrm{H}), 11.60(\mathrm{~s}, 1 \mathrm{H}) ;{ }^{13} \mathrm{C}$ NMR $\left(101 \mathrm{MHz}, \mathrm{CDCl}_{3}\right): \delta 28.1$ $\left(\mathrm{C}\left(\mathrm{CH}_{3}\right)_{3}\right), 41.6\left(\mathrm{CH}_{2}\right), 83.0\left(\mathrm{C}\left(\mathrm{CH}_{3}\right)_{3}\right), 116.1(\mathrm{ArC}), 118.9$ ( $\mathrm{ArC}), 125.8(\mathrm{ArC}), 127.4(\mathrm{ArC}), 129.6(\mathrm{ArC}), 141.2(\mathrm{ArC}), 144.6$ $(\operatorname{ArC}), 146.9(\operatorname{ArC}), 153.5(\operatorname{ArC}), 168.3(C=O), 168.5(C=O)$; HRMS (ESI) $m / z$ : calcd for $\mathrm{C}_{14} \mathrm{H}_{12} \mathrm{~N}_{4} \mathrm{O}_{6}[\mathrm{M}-\mathrm{H}]^{-}$, 331.0684; observed, 331.0684 .

tert-Butyl (3-Hydroxy-6-((5-nitropyridin-2-yl)amino)picolinoyl)glycinate $(12 b)$. The product was prepared according to general procedure $\mathrm{B}$; the use of aryl derivative $8(40 \mathrm{mg}, 0.12 \mathrm{mmol})$ and 5nitropyridin-2-amine (18 mg, $0.13 \mathrm{mmol}$ ) afforded $12 \mathrm{~b}$ (34 mg, 73\%) as a yellow solid. mp $196-200{ }^{\circ} \mathrm{C}$. IR (neat): $\nu / \mathrm{cm}^{-1} 3387(\mathrm{~N}-\mathrm{H})$, $3300(\mathrm{ArO}-\mathrm{H}), 1742(t-\mathrm{BuC}=\mathrm{O}), 1647(\mathrm{NHC}=\mathrm{O}), 1504,1382$ $(\mathrm{N}-\mathrm{O}) ;{ }^{1} \mathrm{H}$ NMR $\left(400 \mathrm{MHz}, \mathrm{CDCl}_{3}\right): \delta 1.47(\mathrm{~s}, 9 \mathrm{H}), 4.07(\mathrm{~d}, J=$ $5.0 \mathrm{~Hz}, 2 \mathrm{H}), 7.32-7.37(\mathrm{~m}, 2 \mathrm{H}), 7.59(\mathrm{~s}, 1 \mathrm{H}), 7.75(\mathrm{~d}, J=9.0 \mathrm{~Hz}$, $1 \mathrm{H}), 8.10-8.16(\mathrm{~m}, 1 \mathrm{H}), 8.33(\mathrm{~s}, 1 \mathrm{H}), 9.07(\mathrm{t}, J=5.0 \mathrm{~Hz}, 1 \mathrm{H}), 11.56$ $(\mathrm{s}, 1 \mathrm{H}) ;{ }^{13} \mathrm{C}$ NMR $\left(101 \mathrm{MHz}, \mathrm{CDCl}_{3}\right): \delta 28.1\left(\mathrm{C}\left(\mathrm{CH}_{3}\right)_{3}\right), 41.6$ $\left(\mathrm{CH}_{2}\right), 68.3\left(\mathrm{C}\left(\mathrm{CH}_{3}\right)_{3}\right), 109.4(\mathrm{ArC}), 120.2(\mathrm{ArC}), 122.3(\mathrm{ArC})$, 129.4 (ArC), 133.5 (ArC), $138.1(\mathrm{ArC}), 143.1(\mathrm{ArC}), 145.9(\mathrm{ArC})$, 154.2 ( $\mathrm{ArC}), 157.1(\mathrm{ArC}), 168.2(\mathrm{C}=\mathrm{O}), 168.7(\mathrm{C}=\mathrm{O})$; HRMS (ESI) $m / z$ : calcd for $\mathrm{C}_{17} \mathrm{H}_{18} \mathrm{~N}_{6} \mathrm{O}_{8}[\mathrm{M}-\mathrm{H}]^{-}, 388.1262$; observed, 388.1266.

Benzyl (3-Hydroxy-6-((4-nitrophenyl)amino)picolinoyl)glycinate (12c). The desired product was prepared according to general procedure B; the use of aryl derivative $9(40 \mathrm{mg}, 0.11 \mathrm{mmol})$ and 4nitroaniline (18 $\mathrm{mg}, 0.13 \mathrm{mmol})$ afforded $12 \mathrm{c}(35 \mathrm{mg}, 76 \%)$ as an orange solid. $\mathrm{mp} 194-196^{\circ} \mathrm{C}$. IR (neat): $\nu / \mathrm{cm}^{-1} 3340(\mathrm{~N}-\mathrm{H}), 3289$ $($ ArO-H $), 1732(t-\mathrm{BuC}=\mathrm{O}), 1633(\mathrm{NHC}=\mathrm{O}), 1469,1319\left(\mathrm{NO}_{2}\right)$; ${ }^{1} \mathrm{H}$ NMR (400 MHz, DMSO- $\left.d_{6}\right): \delta 4.28(\mathrm{~d}, J=6.0 \mathrm{~Hz}, 2 \mathrm{H}), 5.20(\mathrm{~s}$, $2 \mathrm{H}), 7.32-7.43(\mathrm{~m}, 5 \mathrm{H}), 7.46(\mathrm{~d}, J=9.0 \mathrm{~Hz}, 1 \mathrm{H}), 7.58(\mathrm{~d}, J=9.0$ $\mathrm{Hz}, 1 \mathrm{H}), 7.99(\mathrm{~d}, J=1.0 \mathrm{~Hz}, 2 \mathrm{H}), 8.17(\mathrm{~d}, J=1.0 \mathrm{~Hz}, 2 \mathrm{H}), 8.75(\mathrm{t}, J$ $=6.0 \mathrm{~Hz}, 1 \mathrm{H}), 10.99(\mathrm{~s}, 1 \mathrm{H}), 11.99(\mathrm{~s}, 1 \mathrm{H}) ;{ }^{13} \mathrm{C}$ NMR $(101 \mathrm{MHz}$, DMSO-d $\left.d_{6}\right) 49.0\left(\mathrm{CH}_{2}\right), 66.6\left(\mathrm{CH}_{2}\right), 116.5(\mathrm{ArC}), 126.0(\mathrm{ArC})$, 126.4 ( $\mathrm{ArC}), 127.4(\mathrm{ArC}), 128.5(\mathrm{ArC}), 128.9(\mathrm{ArC}), 136.2(\mathrm{ArC})$, 139.4 (ArC), 147.0 (ArC), 148.7 (ArC), 149.5 (ArC), 153.0 (ArC), $166.4(\mathrm{C}=\mathrm{O}), 168.9(\mathrm{C}=\mathrm{O})$; HRMS (ESI) $\mathrm{m} / z$ : calcd for $\mathrm{C}_{21} \mathrm{H}_{16} \mathrm{~N}_{4} \mathrm{O}_{6}[\mathrm{M}-\mathrm{H}]^{-}, 421.1148$; observed, 421.1163.

Benzyl (3-Hydroxy-6-((5-nitropyridin-2-yl)amino)picolinoyl)glycinate (12d). The desired product was prepared according to general procedure B; the use of aryl derivative $9(40 \mathrm{mg}, 0.11 \mathrm{mmol})$ and amine 5-nitropyridin-2-amine $(18 \mathrm{mg}, 0.13 \mathrm{mmol}$ ) afforded $12 \mathrm{~d}$ (30 mg, 65\%) as an orange solid. $\mathrm{mp} 190-195{ }^{\circ} \mathrm{C}$. IR (neat): $\nu / \mathrm{cm}^{-1}$ $3352(\mathrm{~N}-\mathrm{H}), 3340(\mathrm{Ar}-\mathrm{OH}), 1740(\mathrm{MeOC}=\mathrm{O}), 1644(\mathrm{BzOC}=$ $\mathrm{O}), 1605(\mathrm{NHC}=\mathrm{O}), 1542,1324(\mathrm{~N}-\mathrm{O}) ;{ }^{1} \mathrm{H}$ NMR $(400 \mathrm{MHz}$, $\left.\mathrm{CDCl}_{3}\right): \delta 4.22(\mathrm{~d}, J=6.0 \mathrm{~Hz}, 2 \mathrm{H}), 5.21(\mathrm{~s}, 2 \mathrm{H}), 7.25-7.43(\mathrm{~m}, 7 \mathrm{H})$, $7.57(\mathrm{br} \mathrm{s}, 1 \mathrm{H}), 7.69-7.78(\mathrm{~m}, 1 \mathrm{H}), 8.11(\mathrm{br} \mathrm{s}, 1 \mathrm{H}), 8.33(\mathrm{~d}, J=10.0$ $\mathrm{Hz}, 1 \mathrm{H}), 9.00-9.21(\mathrm{~m}, 1 \mathrm{H}), 11.47(\mathrm{~s}, 1 \mathrm{H}) ;{ }^{13} \mathrm{C}$ NMR $(101 \mathrm{MHz}$, $\left.\mathrm{CDCl}_{3}\right): \delta 40.5\left(\mathrm{CH}_{2}\right), 67.6\left(\mathrm{CH}_{2}\right), 109.4(\mathrm{ArC}), 116.5(\mathrm{ArC}), 118.5$ (ArC), 120.25 (ArC), 122.8 (ArC), 129.4 (ArC), 133.5 (ArC), 138.1 (ArC), 143.1 (ArC), 145.9 (ArC), 154.2 (ArC), 157.1 (ArC), 168.2 $(\mathbf{C}=\mathrm{O}), 168.7(\mathrm{C}=\mathrm{O})$; HRMS $(\mathrm{ESI}) \mathrm{m} / z$ : calcd for $\mathrm{C}_{20} \mathrm{H}_{16} \mathrm{~N}_{5} \mathrm{O}_{6}$ $[\mathrm{M}-\mathrm{H}]^{-}, 422.1106$; observed, 422.1110 .

Methyl-4-((5-hydroxy-6-((2-methoxy-2-oxoethyl)carbamoyl)pyridin-2-yl)amino)benzoate (12f). The desired product was prepared according to general procedure $\mathrm{B}$; the use of aryl derivative $10(40 \mathrm{mg}, 0.14 \mathrm{mmol})$ and methyl 4-aminobenzoate $(26 \mathrm{mg}, 0.17$ $\mathrm{mmol}$ ) afforded $12 \mathrm{f}(32 \mathrm{mg}, 64 \%)$ as a yellow solid. $\mathrm{mp} 170-175^{\circ} \mathrm{C}$. ${ }^{1} \mathrm{H}$ NMR (500 MHz, DMSO- $\left.d_{6}\right): \delta 3.71(\mathrm{~s}, 3 \mathrm{H}), 3.81(\mathrm{~s}, 3 \mathrm{H}), 4.20$ $(\mathrm{d}, J=6.0 \mathrm{~Hz}, 2 \mathrm{H}), 7.17(\mathrm{~d}, J=9.0 \mathrm{~Hz}, 1 \mathrm{H}), 7.42(\mathrm{~d}, J=9.0 \mathrm{~Hz}, 1 \mathrm{H})$, $7.69-7.74(\mathrm{~m}, 2 \mathrm{H}), 7.88-7.93(\mathrm{~m}, 2 \mathrm{H}), 8.58(\mathrm{t}, J=6.0 \mathrm{~Hz}, 1 \mathrm{H})$, $9.55(\mathrm{~s}, 1 \mathrm{H}), 11.85(\mathrm{~s}, 1 \mathrm{H}) ;{ }^{13} \mathrm{C}$ NMR $\left(126 \mathrm{MHz}, \mathrm{DMSO}-d_{6}\right): \delta 41.4$ $\left(\mathrm{CH}_{2}\right), 52.1\left(\mathrm{CH}_{3}\right), 52.5\left(\mathrm{CH}_{3}\right), 113.1(\mathrm{ArC}), 116.5(\mathrm{ArC}), 120.8$ (ArC), 120.8 (ArC), 126.3 (ArC), 129.8 (ArC), 131.2 (ArC), 131.6 (ArC), 146.5 (ArC), 147.3 (ArC), $152.5(\operatorname{ArC}), 166.6(\mathrm{C}=\mathrm{O}), 169.6$ $(\mathbf{C}=\mathrm{O}), 170.3(\mathbf{C}=\mathrm{O})$; HRMS $(\mathrm{ESI}) \mathrm{m} / z$ : calcd for $\mathrm{C}_{17} \mathrm{H}_{18} \mathrm{~N}_{3} \mathrm{O}_{6}$ $[\mathrm{M}+\mathrm{H}]^{+}$, 360.1190; observed, 360.1191 .

Methyl-4-((6-((2-(benzyloxy)-2-oxoethyl)carbamoyl)-5-hydroxypyridin-2-yl)amino)benzoate (12g). The desired product was prepared according to general procedure $\mathrm{B}$; the use of aryl derivative 9 (40 mg, $0.11 \mathrm{mmol})$ and methyl 4-aminobenzoate $(20 \mathrm{mg}, 0.13$ $\mathrm{mmol})$ afforded $12 \mathrm{~g}(15 \mathrm{mg}, 32 \%)$ as a yellow solid. $\mathrm{mp} 185-189^{\circ} \mathrm{C}$. IR (neat): $\nu / \mathrm{cm}^{-1} 3408(\mathrm{~N}-\mathrm{H}), 3352(\mathrm{Ar}-\mathrm{OH}), 1740(\mathrm{MeOC}=\mathrm{O})$, $1690(\mathrm{BzOC}=\mathrm{O}), 1651(\mathrm{NHC}=\mathrm{O}) ;{ }^{1} \mathrm{H}$ NMR $\left(400 \mathrm{MHz}, \mathrm{CDCl}_{3}\right)$ : $\delta 3.83(\mathrm{~s}, 3 \mathrm{H}), 4.14-4.25(\mathrm{~m}, 2 \mathrm{H}), 5.19(\mathrm{~s}, 2 \mathrm{H}), 6.59(\mathrm{~s}, 1 \mathrm{H}) 6.97(\mathrm{~d}$, $J=9.0 \mathrm{~Hz}, 1 \mathrm{H}), 7.20-7.35(\mathrm{~m}, 8 \mathrm{H}), 7.88-7.97(\mathrm{~m}, 2 \mathrm{H}), 8.13(\mathrm{t}, J=$ $6.0 \mathrm{~Hz}, 1 \mathrm{H}), 11.33(\mathrm{~s}, 1 \mathrm{H}) ;{ }^{13} \mathrm{C}$ NMR $\left(101 \mathrm{MHz}, \mathrm{CDCl}_{3}\right): \delta 41.0$ $\left(\mathrm{CH}_{2}\right), 51.9\left(\mathrm{CH}_{3}\right), 67.6\left(\mathrm{CH}_{2}\right), 116.5(\mathrm{ArC}), 118.5(\mathrm{ArC}), 122.8$ ( $\mathrm{ArC}), 127.0$ ( $\mathrm{ArC}), 128.6(\mathrm{ArC}), 128.7$ ( $\mathrm{ArC}), 128.7$ ( $\mathrm{ArC}), 129.4$ (ArC), 131.3 (ArC), 135.0 (ArC), $145.2(\operatorname{ArC}), 145.6(\mathrm{ArC}), 152.9$ $(\mathrm{ArC}), 166.9(\mathrm{C}=\mathrm{O}), 168.8(\mathrm{C}=\mathrm{O}), 169.3(\mathrm{C}=\mathrm{O})$; HRMS (ESI) $m / z$ : calcd for $\mathrm{C}_{23} \mathrm{H}_{21} \mathrm{~N}_{3} \mathrm{O}_{6}[\mathrm{M}-\mathrm{H}]^{-}$, 434.1357; observed, 434.1359.

Benzyl (3-Hydroxy-6-((4-(methylcarbamoyl)phenyl)amino)picolinoyl)glycinate (12h). The desired product was prepared according to general procedure B; the use of aryl derivative 9 (40 $\mathrm{mg}, 0.11 \mathrm{mmol})$ and 4-amino- $\mathrm{N}$-methylbenzamide $(20 \mathrm{mg}, 0.13$ $\mathrm{mmol})$ afforded $12 \mathrm{~h}(30 \mathrm{mg}, 64 \%)$ as a yellow solid. $\mathrm{mp} 165-167^{\circ} \mathrm{C}$. IR (neat): $\nu / \mathrm{cm}^{-1} 3402(\mathrm{NH}), 3300(\mathrm{ArOH}), 1741(\mathrm{BzOC}=\mathrm{O})$, $1646(\mathrm{HNC}=\mathrm{O}), 1602(\mathrm{HNC}=\mathrm{O}) ;{ }^{1} \mathrm{H}$ NMR $\left(400 \mathrm{MHz}, \mathrm{CDCl}_{3}\right)$ : $\delta 2.95(\mathrm{~d}, J=6.0 \mathrm{~Hz}, 3 \mathrm{H}), 4.20(\mathrm{~d}, J=6.0 \mathrm{~Hz}, 2 \mathrm{H}), 5.19(\mathrm{~s}, 2 \mathrm{H})$, 5.96-6.07 (m, 1H), $6.48(\mathrm{~s}, 1 \mathrm{H}), 6.93(\mathrm{~d}, J=9.0 \mathrm{~Hz}, 1 \mathrm{H}), 7.20-7.35$ $(\mathrm{m}, 8 \mathrm{H}), 7.66(\mathrm{~d}, J=8.5 \mathrm{~Hz}, 2 \mathrm{H}), 8.13(\mathrm{t}, J=6.0 \mathrm{~Hz}, 1 \mathrm{H}), 11.30(\mathrm{~s}$, $1 \mathrm{H}) ;{ }^{13} \mathrm{C}$ NMR (101 MHz, CDCl $): \delta 41.0\left(\mathrm{CH}_{2}\right), 51.9\left(\mathrm{CH}_{3}\right), 67.6$ $\left(\mathrm{CH}_{2}\right), 116.5$ ( $\left.\mathrm{ArC}\right), 118.5$ (ArC), $122.8(\mathrm{ArC}), 127.0(\mathrm{ArC}), 128.6$ (ArC), 128.7 (ArC), 128.73 (ArC), 129.4 (ArC), 131.3 (ArC), 135.0 ( $\mathrm{ArC}), 145.2(\mathrm{ArC}), 145.6(\mathrm{ArC}), 152.9(\mathrm{ArC}), 166.9(\mathrm{C}=\mathrm{O}), 168.8$ $(\mathrm{C}=\mathrm{O}), 169.3(\mathrm{C}=\mathrm{O})$; HRMS (ESI) $\mathrm{m} / z$ : calcd for $\mathrm{C}_{23} \mathrm{H}_{21} \mathrm{~N}_{4} \mathrm{O}_{5}$ $[\mathrm{M}-\mathrm{H}]^{-}$, 433.1517; observed, 433.1523.

Benzyl (3-Hydroxy-6-((4-(dimethylcarbamoyl)phenyl)amino)picolinoyl)glycinate (12i). The desired product was prepared according to general procedure B; the use of aryl derivative 9 (40 $\mathrm{mg}, 0.11 \mathrm{mmol}$ ) and 4-amino- $\mathrm{N}, \mathrm{N}$-dimethylbenzamide $(21 \mathrm{mg}, 0.13$ $\mathrm{mmol}$ ) afforded $12 \mathrm{i}(32 \mathrm{mg}, 65 \%)$ as a yellow solid. $\mathrm{mp} 201-204^{\circ} \mathrm{C}$. IR (neat): $\nu / \mathrm{cm}^{-1} 3323(\mathrm{~b}, \mathrm{NH}, \mathrm{ArOH}), 1750(\mathrm{BzOC}=\mathrm{O}), 1632$ $(\mathrm{HNC}=\mathrm{O}), 1601\left(\mathrm{Me}_{2} \mathrm{NC}=\mathrm{O}\right) ;{ }^{1} \mathrm{H}$ NMR $\left(400 \mathrm{MHz}, \mathrm{CDCl}_{3}\right): \delta$ $3.02(\mathrm{br} \mathrm{s}, 6 \mathrm{H}), 4.20(\mathrm{~d}, J=6.0 \mathrm{~Hz}, 2 \mathrm{H}), 5.18(\mathrm{~s}, 2 \mathrm{H}), 6.38(\mathrm{~s}, 1 \mathrm{H})$, $6.94(\mathrm{~d}, J=9.0 \mathrm{~Hz}, 1 \mathrm{H}), 7.21-7.34(\mathrm{~m}, 8 \mathrm{H}), 7.34-7.39(\mathrm{~m}, 2 \mathrm{H})$, $8.16(\mathrm{t}, J=6.0 \mathrm{~Hz}, 1 \mathrm{H}), 11.28(\mathrm{~s}, 1 \mathrm{H}) ;{ }^{13} \mathrm{C}$ NMR $(101 \mathrm{MHz}$, $\left.\mathrm{CD}_{3} \mathrm{COCD}_{3}-d_{6}\right): \delta 26.6\left(\mathrm{CH}_{3}\right), 40.8\left(\mathrm{CH}_{2}\right), 66.5\left(\mathrm{CH}_{2}\right), 113.0$ ( $\mathrm{ArC}), 116.6(\mathrm{ArC}), 119.5(\mathrm{ArC}), 126.0(\mathrm{ArC}), 128.2(\mathrm{ArC}), 128.5$ (ArC), 128.6 (ArC), 129.0 (ArC), 129.2 (ArC), 136.1 (ArC), 143.1 $(\mathrm{ArC}), 147.5(\mathrm{ArC}), 152.2(\mathrm{ArC}), 169.2(\mathrm{C}=\mathrm{O}), 169.5(\mathrm{C}=\mathrm{O})$, $170.6(\mathrm{C}=\mathrm{O})$; HRMS (ESI) $m / z$ : calcd for $\mathrm{C}_{24} \mathrm{H}_{23} \mathrm{~N}_{4} \mathrm{O}_{5}[\mathrm{M}-\mathrm{H}]^{-}$, 447.1674; observed, 447.1675.

3-Hydroxy-6-(((4-nitrophenyl)amino)picolinoyl)glycine (14a). The desired product was prepared according to general procedure D; glycinate 12a (20 mg, $0.05 \mathrm{mmol})$ afforded $14 \mathrm{a}(10 \mathrm{mg}, 66 \%)$ as a yellow solid. $\mathrm{mp}>300{ }^{\circ} \mathrm{C}$. IR(neat): $\nu / \mathrm{cm}^{-1} 3387(\mathrm{NH}), 3386$ $(\mathrm{ArOH}), 2939(\mathrm{COO}-\mathrm{H}), 1728(\mathrm{HOC}=\mathrm{O}), 1647(\mathrm{HNC}=\mathrm{O})$, 1577, $1334(\mathrm{~N}-\mathrm{O}) ;{ }^{1} \mathrm{H}$ NMR (400 MHz, DMSO- $\left.d_{6}\right): \delta 4.09(\mathrm{~d}, J=$ $5.0 \mathrm{~Hz}, 2 \mathrm{H}), 7.22(\mathrm{~d}, J=9.0 \mathrm{~Hz}, 1 \mathrm{H}), 7.47(\mathrm{~d}, J=9.0 \mathrm{~Hz}, 1 \mathrm{H}), 7.81$ $(\mathrm{d}, J=1.0 \mathrm{~Hz}, 2 \mathrm{H}), 8.18(\mathrm{~d}, J=1.0 \mathrm{~Hz}, 2 \mathrm{H}), 8.83(\mathrm{br} \mathrm{s}, 1 \mathrm{H}), 9.96(\mathrm{t}$, $J=5.0 \mathrm{~Hz}, 1 \mathrm{H}), 11.98(\mathrm{~s}, 1 \mathrm{H}), 12.96(\mathrm{br} \mathrm{s}, 1 \mathrm{H}) ;{ }^{13} \mathrm{C}$ NMR $(101$ MHz, DMSO- $\left.d_{6}\right): \delta 28.5\left(\mathrm{CH}_{2}\right), 112.4(\mathrm{ArC}), 121.5(\mathrm{ArC}), 128.6$ ( $\mathrm{ArC}$ ), 130.3 (ArC), 133.8 (ArC), 137.5 (ArC), 144.6 ( $\mathrm{ArC}), 158.2$ 
(ArC), $169.0(\operatorname{ArC}), 172.7(\mathbf{C}=\mathrm{O}), 178.5(\mathrm{C}=\mathrm{O})$; HRMS (ESI) $\mathrm{m} /$ $z$ : calcd for $\mathrm{C}_{16} \mathrm{H}_{15} \mathrm{~N}_{4} \mathrm{O}_{5}[\mathrm{M}-\mathrm{H}]^{-}$, 331.0684; observed, 331.0685.

3-Hydroxy-6-(((5-nitropyridin-2-yl)amino)picolinoyl)glycine (14b). The desired product was prepared according to general procedure D; glycinate $12 \mathrm{~b}(20 \mathrm{mg}, 0.05 \mathrm{mmol})$ afforded $14 \mathbf{b}$ (14 $\mathrm{mg}, 78 \%)$ as a yellow solid. $\mathrm{mp}>300{ }^{\circ} \mathrm{C}$. IR (neat): $\nu / \mathrm{cm}^{-1} 3400$ $(\mathrm{NH}), 3300(\mathrm{ArOH}), 2856(\mathrm{COO}-\mathrm{H}) 1725(\mathrm{HOC}=\mathrm{O}), 1647$ $(\mathrm{HNC}=\mathrm{O}), 1577,1334(\mathrm{~N}-\mathrm{O}) ;{ }^{1} \mathrm{H}$ NMR $\left(400 \mathrm{MHz}, \mathrm{DMSO}-d_{6}\right): \delta$ $4.09(\mathrm{~d}, J=6.0 \mathrm{~Hz}, 2 \mathrm{H}), 7.53(\mathrm{~d}, J=9.0 \mathrm{~Hz}, 1 \mathrm{H}), 7.77(\mathrm{~d}, J=9.0$, $1 \mathrm{H}), 7.84(\mathrm{~d}, J=9.0 \mathrm{~Hz}, 1 \mathrm{H}), 8.39(\mathrm{dd}, J=9.0,3.0 \mathrm{~Hz}, 1 \mathrm{H}), 8.66(\mathrm{t}, J$ $=6.0 \mathrm{~Hz}, 1 \mathrm{H}), 9.09(\mathrm{~d}, J=3.0 \mathrm{~Hz}, 1 \mathrm{H}), 10.66(\mathrm{~s}, 1 \mathrm{H}), 11.98(\mathrm{~s}, 1 \mathrm{H})$; ${ }^{13} \mathrm{C}$ NMR (101 MHz, DMSO- $\left.d_{6}\right): \delta 21.5\left(\mathrm{CH}_{2}\right), 110.4(\mathrm{ArC}), 121.9$ (ArC), 127.5 (ArC), 129.5 ( $\mathrm{ArC}), 133.8(\mathrm{ArC}), 137.5(\mathrm{ArC}), 144.6$ (ArC), 146.0 (ArC), 153.8 (ArC), $158.2(\operatorname{ArC}), 171.0(\mathrm{C}=\mathrm{O}), 172.4$ $\left(\mathbf{C}=\mathrm{O}\right.$ ); HRMS (ESI) $\mathrm{m} / z$ : calcd for $\mathrm{C}_{13} \mathrm{H}_{10} \mathrm{~N}_{5} \mathrm{O}_{6}[\mathrm{M}-\mathrm{H}]^{-}$, 332.0636; observed, 332.0636.

6-(((4-Aminophenyl)amino)-3-hydroxypicolinoyl)glycine (14c). The desired product was prepared according to general procedure C; glycinate $12 \mathrm{c}(20 \mathrm{mg}, 0.05 \mathrm{mmol})$ afforded $14 \mathrm{c}(6 \mathrm{mg}, 43 \%)$ as a violet solid. $\mathrm{mp}>300{ }^{\circ} \mathrm{C}$. IR (neat): $\nu / \mathrm{cm}^{-1} 3298$ (b, N-H, ArO$\mathrm{H}), 2952(\mathrm{COO}-\mathrm{H}), 1720(\mathrm{HOC}=\mathrm{O}), 1630(\mathrm{HNC}=\mathrm{O}) ;{ }^{1} \mathrm{H}$ NMR (400 MHz, DMSO- $\left.d_{6}\right): \delta 4.22-4.29(\mathrm{~m}, 2 \mathrm{H}), 5.21(\mathrm{br} \mathrm{s}, 2 \mathrm{H})$, $7.30-7.46(\mathrm{~m}, 6 \mathrm{H}), 7.66($ br s, $1 \mathrm{H}), 8.18(\mathrm{t}, J=6.0 \mathrm{~Hz}, 1 \mathrm{H}), 11.70$ (br s, $1 \mathrm{H}) ;{ }^{13} \mathrm{C}$ NMR $\left(101 \mathrm{MHz}, \mathrm{DMSO}-d_{6}\right): \delta 49.0\left(\mathrm{CH}_{2}\right), 116.5$ ( $\mathrm{ArC}$ ), 126.0 (ArC), 126.4 (ArC), 128.5 (ArC), 128.6 (ArC), 128.9 (ArC), 129.7 (ArC), 136.2 (ArC), 139.4 (ArC), 153.0 (ArC), 166.4 $(\mathbf{C}=\mathrm{O}), 169.8(\mathrm{C}=\mathrm{O})$; HRMS (ESI) $\mathrm{m} / z$ : calcd for $\mathrm{C}_{16} \mathrm{H}_{14} \mathrm{~N}_{3} \mathrm{O}_{6}$ $[\mathrm{M}-\mathrm{H}]^{-}$, 302.1015; observed, 302.1008.

6-(((5-Aminopyridin-2-yl)amino)-3-hydroxypicolinoyl)glycine (14d). The desired product was prepared according to general procedure $C$; glycinate $12 \mathrm{~d}(20 \mathrm{mg}, 0.047 \mathrm{mmol})$ afforded $14 \mathrm{~d}$ (3 $\mathrm{mg}, 21 \%)$ as a violet solid. $\mathrm{mp}>300{ }^{\circ} \mathrm{C}$. IR (neat): $\nu / \mathrm{cm}^{-1} 3250(\mathrm{~b}$, $\mathrm{N}-\mathrm{H}, \mathrm{ArO}-\mathrm{H}), 3000(\mathrm{COO}-\mathrm{H}), 1721(\mathrm{HOC}=\mathrm{O}), 1680(\mathrm{HNC}=$ $\mathrm{O}) ;{ }^{1} \mathrm{H}$ NMR $\left(400 \mathrm{MHz}, \mathrm{DMSO}-d_{6}\right): \delta 4.16(\mathrm{~d}, J=6.0 \mathrm{~Hz}, 2 \mathrm{H}), 7.47$ $(\mathrm{d}, J=9.0 \mathrm{~Hz}, 1 \mathrm{H}), 7.56-7.62(\mathrm{~m}, 1 \mathrm{H}), 7.84-7.89(\mathrm{~m}, 2 \mathrm{H}), 8.14-$ $8.17(\mathrm{~m}, 2 \mathrm{H}), 8.51(\mathrm{t}, J=6.0 \mathrm{~Hz}, 1 \mathrm{H}), 8.98(\mathrm{~s}, 1 \mathrm{H}), 9.14(\mathrm{~s}, 1 \mathrm{H})$, 11.49 (br s, $1 \mathrm{H}), 11.67(\mathrm{~s}, 1 \mathrm{H}) ;{ }^{13} \mathrm{C}$ NMR $\left(101 \mathrm{MHz}\right.$, DMSO- $\left.d_{6}\right): \delta$ $41.6\left(\mathrm{CH}_{2}\right), 109.4(\mathrm{ArC}), 120.2(\mathrm{ArC}), 126.3(\mathrm{ArC}), 128.7(\mathrm{ArC})$, 129.6 ( $\mathrm{ArC}), 136.2(\mathrm{ArC}), 143.1(\mathrm{ArC}), 145.9(\mathrm{ArC}), 154.2(\mathrm{ArC})$, 157.08 (ArC), $165.8(\mathbf{C}=\mathrm{O}), 170.2(\mathbf{C}=\mathrm{O})$; HRMS $(\mathrm{ESI}) \mathrm{m} / \mathrm{z}$ : calcd for $\mathrm{C}_{14} \mathrm{H}_{13} \mathrm{~N}_{4} \mathrm{O}_{4}[\mathrm{M}-\mathrm{H}]^{-}$, 301.0942; observed, 301.0942.

(3-Hydroxy-6-(naphthalen-2-ylamino)picolinoyl)glycine (14e). The desired product was prepared according to general procedure B; glycinate 8 ( $40 \mathrm{mg}, 0.12 \mathrm{mmol})$ was reacted with 2-naphthylamine $(19 \mathrm{mg}, 0.13 \mathrm{mmol})$ and the crude was reacted according to general procedure D to give $14 \mathrm{e}(10 \mathrm{mg}, 25 \%) .{ }^{1} \mathrm{H}$ NMR (500 MHz, DMSO$\left.d_{6}\right): \delta 4.05(\mathrm{~d}, J=5.7 \mathrm{~Hz}, 2 \mathrm{H}), 7.27(\mathrm{~d}, J=9.0 \mathrm{~Hz}, 1 \mathrm{H}), 7.37(\mathrm{~d}, J=$ $9.0 \mathrm{~Hz}, 1 \mathrm{H}), 7.47(\mathrm{t}, J=8.0 \mathrm{~Hz}, 1 \mathrm{H}), 7.51-7.56(\mathrm{~m}, 2 \mathrm{H}), 7.59(\mathrm{~d}, J=$ $8.0 \mathrm{~Hz}, 1 \mathrm{H}), 7.89-7.93(\mathrm{~m}, 1 \mathrm{H}), 7.98(\mathrm{dd}, J=7.5,1.0 \mathrm{~Hz}, 1 \mathrm{H})$, 8.24-8.28 (m, 1H), $8.44(\mathrm{t}, J=6.0 \mathrm{~Hz}, 1 \mathrm{H}), 8.85(\mathrm{~s}, 1 \mathrm{H}), 11.67(\mathrm{~s}$, $1 \mathrm{H}) ;{ }^{13} \mathrm{C}$ NMR $\left(126 \mathrm{MHz}, \mathrm{DMSO}-d_{6}\right): \delta 41.2\left(\mathrm{CH}_{2}\right), 116.1(\mathrm{ArC})$, 119.7 (ArC), 122.4 (ArC), 122.8 (ArC), 125.7 (ArC), 126.3 (ArC), 126.7 (ArC), 126.8 (ArC), 128.7 (ArC), 129.5 (ArC), 134.6 (ArC), 135.3 (ArC), $137.2(\mathrm{ArC}), 151.7(\mathrm{ArC}), 169.4(\mathrm{C}=\mathrm{O}), 171.1(\mathrm{C}=$ O); HRMS (ESI) $m / z$ : calcd for $\mathrm{C}_{18} \mathrm{H}_{16} \mathrm{~N}_{3} \mathrm{O}_{4}[\mathrm{M}+\mathrm{H}]^{+}, 338.1135$; observed, 338.1135 .

4-((6-((Carboxymethyl)carbamoyl)-5-hydroxypyridin-2-yl)amino)benzoic Acid (14f). To a solution of the methyl ester (12f, $359 \mathrm{mg}, 1 \mathrm{mmol})$ in 1,4-dioxane $(5 \mathrm{~mL}), 1 \mathrm{M}$ lithium hydroxide (50 $\mathrm{mg}, 2 \mathrm{mmol}$ ) was added. The mixture was stirred at room temperature for $24 \mathrm{~h}$ until consumption of the starting material and then acidified with acetic acid to $\mathrm{pH} 3$ and diluted with $\mathrm{CH}_{2} \mathrm{Cl}_{2}$. The solution was washed with water, dried over $\mathrm{MgSO}_{4}$, and concentrated in vacuo to afford $14 \mathrm{f}(100 \mathrm{mg}, 30 \%)$ as a white solid. $\mathrm{mp}>300{ }^{\circ} \mathrm{C}$. ${ }^{1} \mathrm{H}$ NMR (500 MHz, DMSO- $\left.d_{6}\right): \delta 4.10(\mathrm{~d}, J=5.5 \mathrm{~Hz}, 2 \mathrm{H}), 7.32(\mathrm{~d}$, $J=9.0 \mathrm{~Hz}, 1 \mathrm{H}), 7.39(\mathrm{~d}, J=9.0 \mathrm{~Hz}, 1 \mathrm{H}), 7.77(\mathrm{~d}, J=9.0 \mathrm{~Hz}, 2 \mathrm{H})$, $7.87(\mathrm{~d}, J=9.0 \mathrm{~Hz}, 2 \mathrm{H}), 8.50(\mathrm{t}, J=6.0 \mathrm{~Hz}, 1 \mathrm{H}), 9.95(\mathrm{~s}, 1 \mathrm{H}), 11.84$ $(\mathrm{s}, 1 \mathrm{H}) ;{ }^{13} \mathrm{C}$ NMR $\left(151 \mathrm{MHz}, \mathrm{DMSO}-d_{6}\right): \delta 41.5\left(\mathrm{CH}_{2}\right), 113.0$ (ArC), 116.5 ( $\mathrm{ArC}), 120.6(\mathrm{ArC}), 122.0$ (ArC), $126.2(\mathrm{ArC}), 129.6$ (ArC), 131.2 (ArC), 131.6 (ArC), 146.3 (ArC), 147.6 (ArC), 152.2
(ArC), $167.7(\mathrm{C}=\mathrm{O}), 169.3(\mathrm{C}=\mathrm{O}), 171.2(\mathrm{C}=\mathrm{O})$; HRMS (ESI) $m / z$ : calcd for $\mathrm{C}_{15} \mathrm{H}_{12} \mathrm{~N}_{3} \mathrm{O}_{6}[\mathrm{M}-\mathrm{H}]^{-}, 330.0732$; observed, 330.0729 .

3-Hydroxy-6-(((4-(methoxycarbonyl)phenyl)amino)picolinoyl)glycine (14g). The desired product was prepared according to general procedure C; glycinate $12 \mathrm{~g}(20 \mathrm{mg}, 0.05 \mathrm{mmol})$ afforded $14 \mathrm{~g}(13 \mathrm{mg}$, $82 \%)$ as a white solid. $\mathrm{mp} 264-267{ }^{\circ} \mathrm{C}$. IR (neat): $\nu / \mathrm{cm}^{-1} 3400$ $(\mathrm{NH}), 3370(\mathrm{ArOH}), 2930(\mathrm{COO}-\mathrm{H}), 1710(\mathrm{MeOC}=\mathrm{O}), 1682$ $(\mathrm{HOC}=\mathrm{O}), 1592(\mathrm{HNC}=\mathrm{O}) ;{ }^{1} \mathrm{H}$ NMR $\left(400 \mathrm{MHz}, \mathrm{DMSO}-d_{6}\right): \delta$ $3.81(\mathrm{~s}, 3 \mathrm{H}), 4.09$ (d, $J=5.5 \mathrm{~Hz}, 2 \mathrm{H}) 7.16(\mathrm{~d}, J=9.0 \mathrm{~Hz}, 1 \mathrm{H}), 7.41$ $(\mathrm{d}, J=9.0 \mathrm{~Hz}, 1 \mathrm{H}), 7.73(\mathrm{~d}, J=1.0 \mathrm{~Hz}, 2 \mathrm{H}), 7.91(\mathrm{~d}, J=1.0 \mathrm{~Hz}, 2 \mathrm{H})$, $8.49(\mathrm{t}, J=5.5 \mathrm{~Hz}, 1 \mathrm{H}), 9.55(\mathrm{~s}, 1 \mathrm{H}), 11.87(\mathrm{br} \mathrm{s}, 1 \mathrm{H}) ;{ }^{13} \mathrm{C} \mathrm{NMR}$ $\left(101 \mathrm{MHz}, \mathrm{DMSO}-d_{6}\right): \delta 49.1\left(\mathrm{CH}_{2}\right), 52.0\left(\mathrm{CH}_{3}\right), 116.5(\mathrm{ArC})$, 120.5 (ArC), 120.9 (ArC), $126.4(\operatorname{ArC}), 129.8$ (ArC), 131.1 (ArC), 146.5 (ArC), $147.2(\operatorname{ArC}), 152.3(\operatorname{ArC}), 166.5(\mathrm{C}=\mathrm{O}), 169.2(\mathrm{C}=$ $\mathrm{O}), 171.2(\mathbf{C}=\mathrm{O})$; HRMS (ESI) $m / z$ : calcd for $\mathrm{C}_{16} \mathrm{H}_{14} \mathrm{~N}_{3} \mathrm{O}_{6}[\mathrm{M}-$ $\mathrm{H}]^{-}$, 344.0888; observed, 334.0888.

3-Hydroxy-6-(((4-(methylcarbamoyl)phenyl)amino)picolinoyl)glycine (14h). The desired product was prepared according to general procedure C; glycinate $12 \mathrm{~h}(30 \mathrm{mg}, 0.07 \mathrm{mmol})$ afforded $14 \mathrm{~h}(12$ $\mathrm{mg}, 51 \%)$ as a yellow solid. $\mathrm{mp}>300{ }^{\circ} \mathrm{C}$. IR(neat): $\nu / \mathrm{cm}^{-1} 3402$ $(\mathrm{NH}), 3330(\mathrm{ArOH}), 2946(\mathrm{COO}-\mathrm{H}), 1728(\mathrm{HOC}=\mathrm{O}), 1645$ $(\mathrm{HNC}=\mathrm{O}), 1602(\mathrm{HNC}=\mathrm{O}) ;{ }^{1} \mathrm{H}$ NMR $\left(400 \mathrm{M}, \mathrm{DMSO}-d_{6}\right): \delta$ $2.77(\mathrm{~d}, J=4.5 \mathrm{~Hz}, 3 \mathrm{H}), 4.08(\mathrm{~d}, J=5.5 \mathrm{~Hz}, 2 \mathrm{H}), 7.13(\mathrm{~d}, J=9.0 \mathrm{~Hz}$, $1 \mathrm{H}), 7.39(\mathrm{~d}, J=9.0 \mathrm{~Hz}, 1 \mathrm{H}), 7.65(\mathrm{~d}, J=1.0 \mathrm{~Hz}, 2 \mathrm{H}), 7.80(\mathrm{~d}, J=$ $1.0 \mathrm{~Hz}, 2 \mathrm{H}), 8.18-8.21(\mathrm{~m}, 2 \mathrm{H}), 8.52(\mathrm{t}, J=5.5 \mathrm{~Hz}, 1 \mathrm{H}), 9.31(\mathrm{~s}$, $1 \mathrm{H}), 11.82(\mathrm{~s}, 1 \mathrm{H}) ;{ }^{13} \mathrm{C}$ NMR $\left(101 \mathrm{MHz}\right.$, DMSO- $\left.d_{6}\right): \delta 26.6\left(\mathrm{CH}_{3}\right)$, $49.1\left(\mathrm{CH}_{2}\right), 116.4(\mathrm{ArC}), 120.2(\mathrm{ArC}), 126.3(\mathrm{ArC}), 128.7(\mathrm{ArC})$, 129.6 (ArC), $144.6(\operatorname{ArC}), 147.6(\operatorname{ArC}), 152.0(\operatorname{ArC}), 166.8(\operatorname{ArC})$, $169.4(\mathrm{ArC}), 171.1(\mathrm{C}=\mathrm{O}), 180.0(\mathrm{C}=\mathrm{O}), 208.8(\mathrm{C}=\mathrm{O})$; HRMS (ESI) $\mathrm{m} / z$ : calcd for $\mathrm{C}_{16} \mathrm{H}_{15} \mathrm{~N}_{4} \mathrm{O}_{5}[\mathrm{M}-\mathrm{H}]^{-}, 343.1048$; observed, 343.1048 .

6-((4-(Dimethylcarbamoyl)phenyl)amino)-3-hydroxypicolinoyl)glycine (14i). The desired product was prepared according to general procedure C; glycinate $12 \mathbf{i}(12 \mathrm{mg}, 0.03 \mathrm{mmol})$ afforded $14 \mathbf{i}(3 \mathrm{mg}$ $30 \%)$ as a white solid. $\mathrm{mp}>300{ }^{\circ} \mathrm{C}$. IR(neat): $\nu / \mathrm{cm}^{-1} 3449(\mathrm{NH})$, $3387(\mathrm{ArOH}), 2863(\mathrm{COO}-\mathrm{H}), 1730(\mathrm{HOC}=\mathrm{O}), 1647(\mathrm{HNC}=$ O), $1592(\mathrm{HNC}=\mathrm{O}) ;{ }^{1} \mathrm{H}$ NMR $\left(400 \mathrm{MHz}, \mathrm{DMSO}-d_{6}\right): \delta 2.98(\mathrm{~s}$, $6 \mathrm{H}), 4.02(\mathrm{~d}, J=5.5 \mathrm{~Hz}, 2 \mathrm{H}), 7.12(\mathrm{~d}, J=9.0 \mathrm{~Hz}, 1 \mathrm{H}), 7.37(\mathrm{~d}, J=$ $8.0 \mathrm{~Hz}, 3 \mathrm{H}), 7.66(\mathrm{~d}, J=9.0 \mathrm{~Hz}, 2 \mathrm{H}), 8.50(\mathrm{t}, J=5.5 \mathrm{~Hz}, 1 \mathrm{H}), 9.27$ (s, $1 \mathrm{H}), 11.82(\mathrm{br} \mathrm{s}, 1 \mathrm{H}) ;{ }^{13} \mathrm{C}$ NMR $\left(101 \mathrm{MHz}, \mathrm{DMSO}-d_{6}\right): \delta 21.5$ $\left(\mathrm{CH}_{3}\right), 49.1\left(\mathrm{CH}_{2}\right), 116.6$ ( $\left.\mathrm{ArC}\right), 112.0$ ( $\left.\mathrm{ArC}\right), 126.3$ ( $\left.\mathrm{ArC}\right), 127.9$ (ArC), 129.0 (ArC), 129.6 (ArC), 143.2 (ArC), 147.7 (ArC), 151.8 $(\operatorname{ArC}), 169.2(\mathrm{C}=\mathrm{O}), 170.7(\mathrm{C}=\mathrm{O}), 171.0(\mathrm{C}=\mathrm{O})$; HRMS $(\mathrm{ESI})$ $m / z$ : calcd for $\mathrm{C}_{14} \mathrm{H}_{12} \mathrm{~N}_{4} \mathrm{O}_{6}[\mathrm{M}-\mathrm{H}]^{-}$, 357.1204; observed, 357.1205.

(E)-4-(2-(4-Benzylnicotinoyl)hydrazineyl)-4-oxobut-2-enoic Acid (15). ${ }^{21}$ Compound 15 was synthesized as reported. ${ }^{21}{ }^{1} \mathrm{H}$ NMR $(600$ MHz, DMSO- $\left.d_{6}\right): \delta 4.21(\mathrm{~s}, 2 \mathrm{H}), 6.69(\mathrm{~d}, J=15.5 \mathrm{~Hz}, 1 \mathrm{H}), 7.09(\mathrm{~d}, J$ $=15.5 \mathrm{~Hz}, 1 \mathrm{H}), 7.55-7.16(\mathrm{~m}, 7 \mathrm{H}), 8.63(\mathrm{~d}, J=37.3 \mathrm{~Hz}, 1 \mathrm{H}), 10.91$ $(\mathrm{s}, 1 \mathrm{H}), 10.96(\mathrm{~s}, 1 \mathrm{H}) ;{ }^{13} \mathrm{C}$ NMR $\left(151 \mathrm{MHz}, \mathrm{DMSO}-d_{6}\right): \delta 37.2$ $\left(\mathrm{CH}_{2}\right), 126.6(\mathrm{CH}), 128.6(2 \mathrm{ArC}, \mathrm{CH}), 129.2(2 \mathrm{ArC}), 131.4(2 \mathrm{ArC})$, 134.2 (ArC), 138.9 (ArC), $146.3(\operatorname{ArC}), 151.2(\operatorname{ArC}), 162.3(\mathrm{C}=\mathrm{O})$, $166.1(2 \mathrm{C}=\mathrm{O})$; HRMS (ESI) $\mathrm{m} / z$ : calcd for $\mathrm{C}_{17} \mathrm{H}_{16} \mathrm{~N}_{3} \mathrm{O}_{4}[\mathrm{M}-$ $\mathrm{H}]^{-}$, 326.1141; observed, 326.1135.

Synthesis of PhosphoramiditeProtected $N^{6}$-Methyladenosine (Scheme S5). 3',5'-O-(Di-tert-butyl)silyl-2'-O-dimethyl(tert-butyl)silylinosine (20). ${ }^{52}$ The desired compound was prepared according to a modified version of the reported procedure. ${ }^{52}$ To a stirred suspension of inosine $(2.12 \mathrm{~g}, 8 \mathrm{mmol})$ in $40 \mathrm{~mL}$ of anhydrous DMF at $0{ }^{\circ} \mathrm{C}$, di-tert-butylsilylditrifluoromethanesulfonate $(3.0 \mathrm{~mL}$, $8.8 \mathrm{mmol}$ ) was added dropwise under an $\mathrm{N}_{2}$ atmosphere. After consumption of the starting material ( $30 \mathrm{~min}$, as assessed by TLC), the reaction was quenched immediately with imidazole $(2.7 \mathrm{~g}, 40$ $\mathrm{mmol}$ ) at $0{ }^{\circ} \mathrm{C}$. After $5 \mathrm{~min}$, the reaction was warmed to room temperature. tert-Butyldimethylsilyl chloride $(1.5 \mathrm{~g}, 9.6 \mathrm{mmol})$ was then added portionwise, and the reaction mixture was refluxed at 60 ${ }^{\circ} \mathrm{C}$ for $12 \mathrm{~h}$. The suspension was then cooled to room temperature, water was added, and the precipitate was collected by suction filtration. The filtrate was discarded, and the white precipitate was washed with cold methanol. The methanol layer was evaporated under reduced pressure and the product was crystallized from $\mathrm{CH}_{2} \mathrm{Cl}_{2}$ 
to give a white solid $(4.0 \mathrm{~g}, 98 \%)$. m.p $191-193.4^{\circ} \mathrm{C} . R_{\mathrm{f}} 0.45(3: 2$ cyclohexane/ethyl acetate); ${ }^{1} \mathrm{H}$ NMR $\left(600 \mathrm{MHz}, \mathrm{CDCl}_{3}\right): \delta 0.17$ (s, $3 \mathrm{H}), 0.18(\mathrm{~s}, 3 \mathrm{H}), 0.96(\mathrm{~s}, 9 \mathrm{H}), 1.07(\mathrm{~s}, 9 \mathrm{H}), 1.10(\mathrm{~s}, 9 \mathrm{H}), 4.02-4.09$ $(\mathrm{m}, 1 \mathrm{H}), 4.25(\mathrm{td}, J=10.0,5.0 \mathrm{~Hz}, 1 \mathrm{H}), 4.38(\mathrm{dd}, J=9.5,4.5 \mathrm{~Hz}$, $1 \mathrm{H}), 4.45-4.58(\mathrm{~m}, 2 \mathrm{H}), 5.96(\mathrm{~s}, 1 \mathrm{H}), 7.87(\mathrm{~s}, 1 \mathrm{H}), 8.11(\mathrm{~s}, 1 \mathrm{H})$, $12.56(\mathrm{~s}, 1 \mathrm{H}) ;{ }^{13} \mathrm{C}$ NMR $\left(151 \mathrm{MHz} \mathrm{CDCl}_{3}\right): \delta-5.0,-4.3,18.3$, 20.4, 22.8, 25.9, 27.0, 27.5, 67.8, 74.8, 75.89, 75.94, 92.3, 125.5, 138.3, 144.7, 148.1, 158.9; HRMS (ESI) $m / z$ : calcd for $\mathrm{C}_{24} \mathrm{H}_{43} \mathrm{O}_{4} \mathrm{~N}_{5}{ }^{28} \mathrm{Si}_{2}[\mathrm{M}$ $+\mathrm{H}]^{+}$, 523.2767; observed, 523.2756.

3', 5'-O-Bis(tert-butyl)silyl-2'-O-(tert-butyldimethyl)silyl- $N^{6}-$ methyladenosine (21). The desired compound was prepared according to a modified version of the reported procedure. ${ }^{52}$ To a stirred solution of $3^{\prime}, 5^{\prime}$-O-bis (tert-butylsilyl)-2'-O-(tert-butyldimethylsilyl)inosine (20; $663 \mathrm{mg}, 1.2 \mathrm{mmol})$ and BOP $(0.64 \mathrm{~g}, 1.44 \mathrm{mmol})$ in $20 \mathrm{~mL}$ of THF, DBU $(0.3 \mathrm{~mL}, 1.8 \mathrm{mmol})$ was added dropwise and the mixture was heated at $40{ }^{\circ} \mathrm{C}$. After the consumption of the starting material (40 $\mathrm{min}$, as assessed by TLC), the reaction mixture was cooled to room temperature and methylamine $(0.3 \mathrm{~mL}, 6.0 \mathrm{mmol})$ was added dropwise and the reaction mixture was stirred overnight. The crude product mixture was concentrated under reduced pressure and diluted with ethyl acetate and was washed with water $(3 \times 10$ $\mathrm{mL}$ ). The organic layer was dried (anhydrous $\mathrm{MgSO}_{4}$ ) and concentrated under vacuum. The residue was purified by column chromatography (9:1 to 3:2 cyclohexane/ethyl acetate) which resulted in oil (665 mg, 98\%). $R_{\mathrm{f}}$ 0.20 (7:3 cyclohexane/ethyl acetate); ${ }^{1} \mathrm{H}$ NMR $\left(400 \mathrm{MHz}, \mathrm{CDCl}_{3}\right): \delta 0.00(\mathrm{~s}, 3 \mathrm{H}) 0.02(\mathrm{~s}, 3 \mathrm{H})$ $0.78(\mathrm{~s}, 9 \mathrm{H}) 0.90(\mathrm{~s}, 9 \mathrm{H}) 0.94(\mathrm{~s}, 9 \mathrm{H}) 3.05(\mathrm{~d}, J=1.0 \mathrm{~Hz}, 3 \mathrm{H}) 3.86-$ $3.90(\mathrm{~m}, 1 \mathrm{H}) 4.02-4.10(\mathrm{~m}, 1 \mathrm{H}) 4.34(\mathrm{dd}, J=9.0,5.0 \mathrm{~Hz}, 1 \mathrm{H})$ $4.38-4.44(\mathrm{~m}, 1 \mathrm{H}) 4.47(\mathrm{~d}, J=4.5 \mathrm{~Hz}, 1 \mathrm{H}) 5.76(\mathrm{br} \mathrm{s}, 2 \mathrm{H}) 7.62(\mathrm{~s}$, $1 \mathrm{H}) 8.22(\mathrm{~s}, 1 \mathrm{H}) ;{ }^{13} \mathrm{C}$ NMR $\left(101 \mathrm{MHz}, \mathrm{CDCl}_{3}\right): \delta-5.0,-4.3,18.3$, 20.4, 22.8, 25.9, 27.1, 27.5, 27.6, 67.9, 74.6, 75.5, 75.8, 92.4, 120.5, $125.0,138.0,153.4,155.5$; HRMS (ESI) $m / z$ : calcd for $\mathrm{C}_{25} \mathrm{H}_{46} \mathrm{O}_{4} \mathrm{~N}_{5}{ }^{28} \mathrm{Si}_{2}[\mathrm{M}+\mathrm{H}]^{+}$, 536.3082; observed, 536.3078. Analytical data are consistent with those reported. ${ }^{52}$

$2^{\prime}$-O-(tert-Butyldimethyl)silyl- $N^{6}$-methyladenosine (22). The desired compound was prepared according to the reported procedure. ${ }^{52}$ To a stirred solution of $3^{\prime}, 5^{\prime}-O-b$ is $($ tert-butylsilyl $)-2^{\prime}-O$-(tert-butyldimethylsilyl)- $N^{6}$-methyladenosine $(21 ; 240 \mathrm{mg}, 0.45 \mathrm{mmol})$ in $4 \mathrm{~mL}$ of $\mathrm{CH}_{2} \mathrm{Cl}_{2}$ at $-15^{\circ} \mathrm{C}$, a cooled solution of $(\mathrm{HF})_{x}$.pyridine $(0.06 \mathrm{~mL}$, $2.3 \mathrm{mmol}$ ) in $365 \mu \mathrm{L}$ of pyridine was added. The reaction temperature was maintained at $0{ }^{\circ} \mathrm{C}$ and stirred for $12 \mathrm{~h}$. The reaction was diluted with $\mathrm{CH}_{2} \mathrm{Cl}_{2}$, then washed first with sat. aq $\mathrm{NaHCO}_{3}$ solution and with water $(3 \times 10 \mathrm{~mL})$. The organic layer was dried (anhydrous $\mathrm{MgSO}_{4}$ ) and concentrated under reduced pressure. The residue was purified by column chromatography (9:1 to $3: 2$ cyclohexane/ethyl acetate) which resulted in oil $(160 \mathrm{mg}, 90 \%) . R_{\mathrm{f}}$ 0.15 (2:3 hexane/ethyl acetate); ${ }^{1} \mathrm{H}$ NMR (400 MHz, $\left.\mathrm{CDCl}_{3}\right): \delta 0.00$ $(\mathrm{s}, 3 \mathrm{H}), 0.02(\mathrm{~s}, 3 \mathrm{H}), 0.94(\mathrm{~s}, 9 \mathrm{H}), 3.42(\mathrm{~d}, J=1.0 \mathrm{~Hz}, 3 \mathrm{H}), 3.89(\mathrm{dd}$, $J=10.5,9.0 \mathrm{~Hz}, 1 \mathrm{H}), 4.01-4.11(\mathrm{~m}, 1 \mathrm{H}), 4.34(\mathrm{dd}, J=9.0,5.0 \mathrm{~Hz}$, $1 \mathrm{H}), 4.41(\mathrm{dd}, J=9.0,5.0 \mathrm{~Hz}, 1 \mathrm{H}), 4.47(\mathrm{~d}, J=5.0 \mathrm{~Hz}, 1 \mathrm{H}), 5.76(\mathrm{~s}$, 2H), $7.62(\mathrm{~s}, 1 \mathrm{H}), 8.22(\mathrm{~s}, 1 \mathrm{H}) ;{ }^{13} \mathrm{C}$ NMR $\left(101 \mathrm{MHz}, \mathrm{CDCl}_{3}\right): \delta$ $-5.4,-5.3,17.9,25.6,25.8,27.5,63.5,73.1,74.4,87.8,91.3,119.7$, $140.0,140.1,152.9,155.8$; HRMS (ESI) $\mathrm{m} / \mathrm{z}$ : calcd for $\mathrm{C}_{17} \mathrm{H}_{30} \mathrm{O}_{4} \mathrm{~N}_{5}{ }^{28} \mathrm{Si}[\mathrm{M}+\mathrm{H}]^{+}$, 396.2062; observed, 396.2068. Analytical data are consistent with those reported. ${ }^{52}$

5'-O-(4,4'-Dimethoxytrityl)-2' -O-dimethyl(tert-butyl)silyl- $N^{6}$ methyladenosine (23). The desired compound was prepared according to the reported procedure. ${ }^{52}$ To a stirred solution of $2^{\prime}$ $O$-dimethyl(tert-butyl)silyl- $N^{6}$-methyladenosine $(22 ; 2.6 \mathrm{~g}, 6.6 \mathrm{mmol})$ in $4 \mathrm{~mL}$ of anhydrous pyridine at $0{ }^{\circ} \mathrm{C}, \mathrm{DMTrCl}(2.7 \mathrm{~g}, 8.0 \mathrm{mmol})$ was added portionwise at regular intervals for $12 \mathrm{~h}$. The reaction was quenched by the addition of an excess of anhydrous methanol ( 0.5 $\mathrm{mL}$ ) at room temperature. After $1 \mathrm{~h}$, the solution was concentrated under vacuum. The crude solid was first dissolved and fractioned between aqueous $\mathrm{NaHCO}_{3}$ and ethyl acetate; the organic layer was then washed with water $(3 \times 10 \mathrm{~mL})$. The organic layer was dried $\left(\mathrm{MgSO}_{4}\right)$ and concentrated under vacuum. The residue was purified by column chromatography (9:1 to $3: 2$ cyclohexane/ethyl acetate) resulting in green oil $(3.9 \mathrm{~g}, 85 \%) . R_{\mathrm{f}} 0.45$ (2:3 cyclohexane/ethyl acetate); ${ }^{1} \mathrm{H}$ NMR (400 MHz, $\left.\mathrm{CDCl}_{3}\right): \delta-0.13(\mathrm{~s}, 3 \mathrm{H}) 0.00(\mathrm{~s}, 3 \mathrm{H})$ $0.86(\mathrm{~s}, 9 \mathrm{H}) 2.77(\mathrm{~d}, J=4.0 \mathrm{~Hz}, 1 \mathrm{H}) 3.17(\mathrm{~s}, 3 \mathrm{H}) 3.36-3.43(\mathrm{~m}, 1 \mathrm{H})$ $3.54(\mathrm{dd}, J=10.5,3.5 \mathrm{~Hz}, 1 \mathrm{H}) 3.80(\mathrm{~s}, 6 \mathrm{H}) 4.27(\mathrm{~d}, J=3.5 \mathrm{~Hz}, 1 \mathrm{H})$ $4.33-4.37(\mathrm{~m}, 1 \mathrm{H}) 5.02(\mathrm{t}, J=5.5 \mathrm{~Hz}, 1 \mathrm{H}) 5.85(\mathrm{~d}, J=4.5 \mathrm{~Hz}, 1 \mathrm{H})$ $6.04(\mathrm{br} \mathrm{s}, 2 \mathrm{H}) 6.83(\mathrm{~d}, J=9.0 \mathrm{~Hz}, 4 \mathrm{H}) 7.18-7.28(\mathrm{~m}, 3 \mathrm{H}) 7.36(\mathrm{~d}, J$ $=8.0 \mathrm{~Hz}, 4 \mathrm{H}) 7.47(\mathrm{dd}, J=8.5 \mathrm{~Hz}, 1.5,2 \mathrm{H}) 7.98(\mathrm{~s}, 1 \mathrm{H}) 8.35(\mathrm{~s}$, $1 \mathrm{H}) ;{ }^{13} \mathrm{C}$ NMR $\left(101 \mathrm{MHz}, \mathrm{CDCl}_{3}\right): \delta-5.6,-5.5,18.3,25.8,25.9$, $55.2,60.4,63.0,73.6,75.5,85.0,87.5,89.2,113.4,120.0,127.3,128.1$, $128.3,130.39,130.45,135.9,138.0,145.0,153.0,155.4,158.89$, 158.91; HRMS (ESI) $m / z$ : calcd for $\mathrm{C}_{38} \mathrm{H}_{48} \mathrm{O}_{6} \mathrm{~N}_{5}{ }^{28} \mathrm{Si}[\mathrm{M}+\mathrm{H}]^{+}$, 698.3368; observed, 698.3359. Analytical data are consistent with those reported. ${ }^{52}$

$5^{\prime}-\mathrm{O}-\left(4,4^{\prime}-\right.$ Dimethoxytrityl) $-\left(3^{\prime}-\mathrm{O}-[(2\right.$ cyanoethyl $)(\mathrm{N}, \mathrm{N}-$ diisopropylamino)phosphino]-2'-O-dimethyl(tert-butyl) silyl- $N^{6}$ methyladenosine (24). The desired compound was prepared according to the reported procedure. ${ }^{52}$ To a stirred solution of $5^{\prime}$ $\mathrm{O}$-(4,4'-dimethoxytrityl)-2'-O-dimethyl(tert-butyl) silyl- $\mathrm{N}^{6}$-methyladenosine $(23,500 \mathrm{mg}, 0.7 \mathrm{mmol})$ in anhydrous $\mathrm{CH}_{2} \mathrm{Cl}_{2}$ in an over-dried flask under argon, DIPEA $(1.3 \mathrm{~mL}, 7.2 \mathrm{mmol})$ was added dropwise and the reaction mixture was allowed to stir at $0{ }^{\circ} \mathrm{C}$ for $10 \mathrm{~min}$. (2Cyanoethyl)-N,N-diisopropylchlorophosphoramidite $(0.40 \mathrm{~mL}, 1.8$ $\mathrm{mmol}$ ) was added to the reaction mixture dropwise at $0{ }^{\circ} \mathrm{C}$ under an argon atmosphere. The reaction was stirred at $0{ }^{\circ} \mathrm{C}$ for $30 \mathrm{~min}$, then gradually (about $30 \mathrm{~min}$ ) warmed to room temperature. After another $5 \mathrm{~h}$ under an inert atmosphere, the reaction mixture was treated with a saturated aq $\mathrm{KCl}$ solution, then evaporated by rotary evaporation. The desired product was separated by silica gel column chromatography (1:1:0.01 hexane/ethyl acetate/pyridine) resulting in colorless oil (520 mg, 80\%) yield. $R_{\mathrm{f}} 0.40$ (1:1:0.01 hexane/ethyl acetate/ pyridine); ${ }^{1} \mathrm{H}$ NMR $\left(700 \mathrm{MHz}, \mathrm{CD}_{2} \mathrm{Cl}_{2}\right.$ ) Major peaks are listed. $\delta$ $-0.15(\mathrm{~s}, 3 \mathrm{H}),-0.01(\mathrm{~s}, 3 \mathrm{H}), 0.82(\mathrm{~s}, 9 \mathrm{H}), 1.10(\mathrm{~s}, 3 \mathrm{H}), 1.11(\mathrm{~s}, 3 \mathrm{H})$, $1.22(\mathrm{~s}, 3 \mathrm{H}), 1.22(\mathrm{~s}, 3 \mathrm{H}), 1.65(\mathrm{~s}, 2 \mathrm{H}), 2.62-2.74(\mathrm{~m}, 2 \mathrm{H}), 3.19(\mathrm{~s}$, $3 \mathrm{H}), 3.36(\mathrm{dd}, J=10.5,4.5 \mathrm{~Hz}, 1 \mathrm{H}), 3.54(\mathrm{dd}, J=10.5,4.0 \mathrm{~Hz}, 1 \mathrm{H})$, $3.82(\mathrm{~s}, 6 \mathrm{H}), 3.85-3.93(\mathrm{~m}, 1 \mathrm{H}), 3.95-4.10(\mathrm{~m}, 1 \mathrm{H}), 4.41-4.49(\mathrm{~m}$, $1 \mathrm{H}), 5.12(\mathrm{dd}, J=6.1,4.4 \mathrm{~Hz}, 1 \mathrm{H}), 5.33-5.40(\mathrm{~m}, 2 \mathrm{H}), 5.79(\mathrm{~s}, 1 \mathrm{H})$ $5.99(\mathrm{~d}, J=6.0 \mathrm{~Hz}, 1 \mathrm{H}), 6.78-6.90(\mathrm{~m}, 4 \mathrm{H}), 7.23-7.29(\mathrm{~m}, 1 \mathrm{H})$, 7.28-7.34 (m, 2H), 7.34-7.40 (m, 4H), 7.47-7.52 (m, 2H), $7.94(\mathrm{~s}$, $1 \mathrm{H}), 8.25(\mathrm{~s}, 1 \mathrm{H}) ;{ }^{13} \mathrm{C} \mathrm{NMR}\left(176 \mathrm{MHz}, \mathrm{CD}_{2} \mathrm{Cl}_{2}\right)$ major peaks are listed. $\delta-5.4,-5.0,0.8,17.8,20.4,20.44,21.1,24.37,24.4,25.4$, 25.44, 42.9, 43.0, 55.2, 58.8, 58.9, 63.5, 72.8, 72.9, 74.7, 74.7, 83.46, $83.48,86.5,88.4,113.1,117.8,125.2,126.8,127.8,128.1,128.2$, 129.0, 130.10, 130.14, 135.7, 139.0, 144.9, 153.0, 155.5, 158.6, 158.7; ${ }^{31} \mathrm{P}$ NMR $\left(202 \mathrm{MHz}, \mathrm{CD}_{2} \mathrm{Cl}_{2}\right): \delta 148.0,150.8$.

\section{ASSOCIATED CONTENT}

\section{Supporting Information}

The Supporting Information is available free of charge at https://pubs.acs.org/doi/10.1021/acs.jmedchem.1c01204.

Protein crystallography data collection and refinement statistics, supplementary $\mathrm{IC}_{50}$ table, $\mathrm{IC}_{50}$ curves, reported FTO inhibitors, view of the active site, titration curves, superimposition of the reported AlkB inhibitor binding modes, synthesis of protected glycinate derivatives, tertbutyl group deprotection, benzyl group deprotection, and phosphoramidite protected N6-methyladenosine, HPLC chromatograms of the selected compounds, and supplementary references (PDF)

Molecular formula strings of compounds (CSV)

\section{Accession Codes}

PDB ID Codes: Atomic coordinates and structure factors of the crystal structures of FTO-13c (PDB ID 4QHO), FTO-14a (PDB ID 7E8Z), and AlkB-14a (PDB ID 7NRO) have been deposited in the RCSB Protein Data Bank. Authors will release the atomic coordinates upon publication. 


\section{AUTHOR INFORMATION}

\section{Corresponding Authors}

Wei Shen Aik - Department of Chemistry, Hong Kong Baptist University, Kowloon Tong, Hong Kong SAR 999077, China; Email: aikweishen@hkbu.edu.hk

Michael A. McDonough - The Chemistry Research Laboratory, Department of Chemistry and the Ineos Oxford Institute for Antimicrobial Research, University of Oxford,

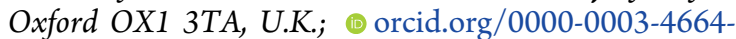
6942; Email: michael.mcdonough@chem.ox.ac.uk

Christopher J. Schofield - The Chemistry Research Laboratory, Department of Chemistry and the Ineos Oxford Institute for Antimicrobial Research, University of Oxford, Oxford OX1 3TA, U.K.; (1) orcid.org/0000-0002-02906565; Email: christopher.schofield@chem.ox.ac.uk

\section{Authors}

Shifali Shishodia - The Chemistry Research Laboratory, Department of Chemistry and the Ineos Oxford Institute for Antimicrobial Research, University of Oxford, Oxford OX1 3TA, U.K.; Present Address: Department of Biochemistry, Medical College of Wisconsin, Milwaukee, Wisconsin 53226, United States

Marina Demetriades - The Chemistry Research Laboratory, Department of Chemistry and the Ineos Oxford Institute for Antimicrobial Research, University of Oxford, Oxford OX1 3TA, U.K.

Dong Zhang - The Chemistry Research Laboratory, Department of Chemistry and the Ineos Oxford Institute for Antimicrobial Research, University of Oxford, Oxford OX1 3TA, U.K.

Nok Yin Tam - Department of Chemistry, Hong Kong Baptist University, Kowloon Tong, Hong Kong SAR 999077, China

Pratheesh Maheswaran - The Chemistry Research Laboratory, Department of Chemistry and the Ineos Oxford Institute for Antimicrobial Research, University of Oxford, Oxford OX1 3TA, U.K.

Caitlin Clunie-O'Connor - The Chemistry Research Laboratory, Department of Chemistry and the Ineos Oxford Institute for Antimicrobial Research, University of Oxford, Oxford OX1 3TA, U.K.

Anthony Tumber - The Chemistry Research Laboratory, Department of Chemistry and the Ineos Oxford Institute for Antimicrobial Research, University of Oxford, Oxford OX1 3TA, U.K.

Ivanhoe K. H. Leung - The Chemistry Research Laboratory, Department of Chemistry and the Ineos Oxford Institute for Antimicrobial Research, University of Oxford, Oxford OX1 3TA, U.K.; Present Address: School of Chemistry and Bio21 Molecular Science and Biotechnology Institute, The University of Melbourne, Parkville, VIC 3010,

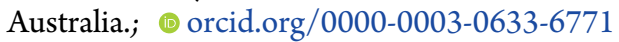

Yi Min Ng - Department of Chemistry, Hong Kong Baptist University, Kowloon Tong, Hong Kong SAR 999077, China

Thomas M. Leissing - The Chemistry Research Laboratory, Department of Chemistry and the Ineos Oxford Institute for Antimicrobial Research, University of Oxford, Oxford OX1 3TA, U.K.

Afaf H. El-Sagheer - The Chemistry Research Laboratory, Department of Chemistry and the Ineos Oxford Institute for Antimicrobial Research, University of Oxford, Oxford OX1 3TA, U.K.; Chemistry Branch Department of Science and
Mathematics, Suez University, Suez 43721, Egypt; (1) orcid.org/0000-0001-8706-1292

Eidarus Salah - The Chemistry Research Laboratory, Department of Chemistry and the Ineos Oxford Institute for Antimicrobial Research, University of Oxford, Oxford OX1 3TA, U.K.

Tom Brown - The Chemistry Research Laboratory, Department of Chemistry and the Ineos Oxford Institute for Antimicrobial Research, University of Oxford, Oxford OX1 3TA, U.K.; orcid.org/0000-0002-6538-3036

Complete contact information is available at:

https://pubs.acs.org/10.1021/acs.jmedchem.1c01204

\section{Author Contributions}

S.S., M.D., D.Z., and C.C.O. synthesized the compounds; A.H.E.-S. and T.B. synthesized the 15-mer RNA; D.Z. and E.S. produced protein; M.D., D.Z., and A.T. optimized and performed the biochemical assays; N.Y.T., P.M., Y.M.N., T.M.L., W.S.A., and M.A.M. performed protein crystallography; S.S., I.K.H.L performed NMR-based binding assay; C.J.S., M.A.M., and W.S.A. supervised the research and analyzed the data; C.J.S., M.A.M., W.S.A., and S.S. wrote the manuscript.

\section{Notes}

The authors declare no competing financial interest.

\section{ACKNOWLEDGMENTS}

W.S.A. thanks the Research Grants Council of Hong Kong for the Early Career Scheme 2019/20 (ref. no. 22301719) for funding. C.J.S. thanks the Biotechnology and Biological Research Council, the Wellcome Trust, and Cancer Research UK for funding. This research was funded in whole, or in part, by the Wellcome Trust [grant no. 106244/Z/14/Z]. S.S. is funded by the Felix Scholarship. S.S. thanks Dr. Adam Hardy, University of Oxford, for useful scientific discussion. We thank the Diamond Light Source and staff for the allocation of beam time and support. For the purpose of open access, the author has applied a CC BY public copyright license to any Author Accepted Manuscript version arising from this submission.

\section{ABBREVIATIONS}

ALKBH, AlkB homologue; CPMG, Carr-Purcell-MeiboomGill; DIPEA, diisopropylethylamine; DMSO, dimethylsulfoxide; ESI, electrospray ionization; ETT, ethylthiotetrazole; $\mathrm{FIH}$, factor inhibiting hypoxia-inducible factor; FTO, fat massand obesity-associated protein; HFIP, 1,1,1,3,3,3-hexafluoro-2propanol; HRMS, high-resolution mass spectra; IPTG, isopropyl $\beta$-D-1-thiogalactopyranoside; $K_{\mathrm{D}}$, dissociation constant; KDM, JmjC histone demethylase; LCMS, liquid chromatography-mass spectrometry; $\mathrm{m}^{6} \mathrm{~A}, N^{6}$-methyladenosine; $\mathrm{m}^{6} \mathrm{Am}, N^{6}-2^{\prime} \mathrm{O}$-dimethyladenosine; $6 \mathrm{~mA}, N^{6}$-methyldeoxyadenosine; $\mathrm{m}^{3} \mathrm{~T}, \mathrm{~N}^{3}$-methylthymidine; $\mathrm{m}^{3} \mathrm{U}, \mathrm{N}^{3}$-methyluridine; NAOX, nucleic acid oxygenase; NMR, nuclear magnetic resonance; 2OG, 2-oxoglutarate; PHD, hypoxia-inducible factor prolyl hydroxylase; Q-TOF, quadrupole time-of-flight; RFMS, Rapidfire mass spectrometry; SPE, solid-phase extraction; ssRNA, single-stranded RNA; TET, ten eleven translocation enzyme

\section{REFERENCES}

(1) Jia, G.; Fu, Y.; Zhao, X.; Dai, Q.; Zheng, G.; Yang, Y.; Yi, C.; Lindahl, T.; Pan, T.; Yang, Y.-G.; He, C. N6-Methyladenosine in 
Nuclear RNA Is a Major Substrate of the Obesity-Associated FTO. Nat. Chem. Biol. 2011, 7, 885-887.

(2) Mauer, J.; Sindelar, M.; Despic, V.; Guez, T.; Hawley, B. R.; Vasseur, J.-J.; Rentmeister, A.; Gross, S. S.; Pellizzoni, L.; Debart, F.; Goodarzi, H.; Jaffrey, S. R. FTO Controls Reversible m ${ }^{6}$ Am RNA Methylation during SnRNA Biogenesis. Nat. Chem. Biol. 2019, 15, 340-347.

(3) Gerken, T.; Girard, C. A.; Tung, Y.-C. L.; Webby, C. J.; Saudek, V.; Hewitson, K. S.; Yeo, G. S. H.; McDonough, M. A.; Cunliffe, S.; McNeill, L. A.; Galvanovskis, J.; Rorsman, P.; Robins, P.; Prieur, X.; Coll, A. P.; Ma, M.; Jovanovic, Z.; Farooqi, I. S.; Sedgwick, B.; Barroso, I.; Lindahl, T.; Ponting, C. P.; Ashcroft, F. M.; O’Rahilly, S.; Schofield, C. J. The Obesity-Associated FTO Gene Encodes a 2Oxoglutarate-Dependent Nucleic Acid Demethylase. Science 2007, 318, 1469-1472.

(4) Frayling, T. M.; Timpson, N. J.; Weedon, M. N.; Zeggini, E.; Freathy, R. M.; Lindgren, C. M.; Perry, J. R. B.; Elliott, K. S.; Lango, H.; Rayner, N. W.; Shields, B.; Harries, L. W.; Barrett, J. C.; Ellard, S.; Groves, C. J.; Knight, B.; Patch, A.-M.; Ness, A. R.; Ebrahim, S.; Lawlor, D. A.; Ring, S. M.; Ben-Shlomo, Y.; Jarvelin, M.-R.; Sovio, U.; Bennett, A. J.; Melzer, D.; Ferrucci, L.; Loos, R. J. F.; Barroso, I.; Wareham, N. J.; Karpe, F.; Owen, K. R.; Cardon, L. R.; Walker, M.; Hitman, G. A.; Palmer, C. N. A.; Doney, A. S. F.; Morris, A. D.; Smith, G. D.; Hattersley, A. T.; McCarthy, M. I. A Common Variant in the FTO Gene Is Associated with Body Mass Index and Predisposes to Childhood and Adult Obesity. Science 2007, 316, 889-894.

(5) Dina, C.; Meyre, D.; Gallina, S.; Durand, E.; Körner, A.; Jacobson, P.; Carlsson, L. M. S.; Kiess, W.; Vatin, V.; Lecoeur, C.; Delplanque, J.; Vaillant, E.; Pattou, F.; Ruiz, J.; Weill, J.; LevyMarchal, C.; Horber, F.; Potoczna, N.; Hercberg, S.; Le Stunff, C.; Bougnères, P.; Kovacs, P.; Marre, M.; Balkau, B.; Cauchi, S.; Chèvre, J.-C.; Froguel, P. Variation in FTO Contributes to Childhood Obesity and Severe Adult Obesity. Nat. Genet. 2007, 39, 724-726.

(6) Huff, S.; Tiwari, S. K.; Gonzalez, G. M.; Wang, Y.; Rana, T. M. $\mathrm{m}^{6} \mathrm{~A}$-RNA Demethylase FTO Inhibitors Impair Self-Renewal in Glioblastoma Stem Cells. ACS Chem. Biol. 2021, 16, 324-333.

(7) Huang, Y.; Su, R.; Sheng, Y.; Dong, L.; Dong, Z.; Xu, H.; Ni, T.; Zhang, Z. S.; Zhang, T.; Li, C.; Han, L.; Zhu, Z.; Lian, F.; Wei, J.; Deng, Q.; Wang, Y.; Wunderlich, M.; Gao, Z.; Pan, G.; Zhong, D.; Zhou, H.; Zhang, N.; Gan, J.; Jiang, H.; Mulloy, J. C.; Qian, Z.; Chen, J.; Yang, C.-G. Small-Molecule Targeting of Oncogenic FTO Demethylase in Acute Myeloid Leukemia. Cancer Cell 2019, 35, 677-691.

(8) Li, Z.; Weng, H.; Su, R.; Weng, X.; Zuo, Z.; Li, C.; Huang, H.; Nachtergaele, S.; Dong, L.; Hu, C.; Qin, X.; Tang, L.; Wang, Y.; Hong, G.-M.; Huang, H.; Wang, X.; Chen, P.; Gurbuxani, S.; Arnovitz, S.; Li, Y.; Li, S.; Strong, J.; Neilly, M. B.; Larson, R. A.; Jiang, X.; Zhang, P.; Jin, J.; He, C.; Chen, J. FTO Plays an Oncogenic Role in Acute Myeloid Leukemia as a N6-Methyladenosine RNA Demethylase. Cancer Cell 2017, 31, 127-141.

(9) Niu, Y.; Lin, Z.; Wan, A.; Chen, H.; Liang, H.; Sun, L.; Wang, Y.; Li, X.; Xiong, X.-f.; Wei, B.; Wu, X.; Wan, G. RNA N6Methyladenosine Demethylase FTO Promotes Breast Tumor Progression through Inhibiting BNIP3. Mol. Cancer 2019, 18, 46.

(10) Cui, Q.; Shi, H.; Ye, P.; Li, L.; Qu, Q.; Sun, G.; Sun, G.; Lu, Z.; Huang, Y.; Yang, C.-G.; Riggs, A. D.; He, C.; Shi, Y. m6 A RNA Methylation Regulates the Self-Renewal and Tumorigenesis of Glioblastoma Stem Cells. Cell Rep. 2017, 18, 2622-2634.

(11) Paris, J.; Morgan, M.; Campos, J.; Spencer, G. J.; Shmakova, A.; Ivanova, I.; Mapperley, C.; Lawson, H.; Wotherspoon, D. A.; Sepulveda, C.; Vukovic, M.; Allen, L.; Sarapuu, A.; Tavosanis, A.; Guitart, A. V.; Villacreces, A.; Much, C.; Choe, J.; Azar, A.; van de Lagemaat, L. N.; Vernimmen, D.; Nehme, A.; Mazurier, F.; Somervaille, T. C. P.; Gregory, R. I.; O'Carroll, D.; Kranc, K. R. Targeting the RNA $\mathrm{m}^{6} \mathrm{~A}$ Reader YTHDF2 Selectively Compromises Cancer Stem Cells in Acute Myeloid Leukemia. Cell Stem Cell 2019, 25, 137-148.
(12) Islam, M. S.; Leissing, T. M.; Chowdhury, R.; Hopkinson, R. J.; Schofield, C. J. 2-Oxoglutarate-Dependent Oxygenases. Annu. Rev. Biochem. 2018, 87, 585-620.

(13) Macdougall, I. C.; Akizawa, T.; Berns, J. S.; Bernhardt, T.; Krueger, T. Effects of Molidustat in the Treatment of Anemia in CKD. Clin. J. Am. Soc. Nephrol. 2019, 14, 28-39.

(14) Chen, H.; Cheng, Q.; Wang, J.; Zhao, X.; Zhu, S. Long-Term Efficacy and Safety of Hypoxia-Inducible Factor Prolyl Hydroxylase Inhibitors in Anaemia of Chronic Kidney Disease: A Meta-Analysis Including 13,146 Patients. J. Clin. Pharmacol. Ther. 2021, 46, 999.

(15) Aik, W.; McDonough, M. A.; Thalhammer, A.; Chowdhury, R.; Schofield, C. J. Role of the Jelly-Roll Fold in Substrate Binding by 2Oxoglutarate Oxygenases. Curr. Opin. Struct. Biol. 2012, 22, 691-700.

(16) Thalhammer, A.; Aik, W.; Bagg, E. A. L.; Schofield, C. J. The Potential of 2-Oxoglutarate Oxygenases Acting on Nucleic Acids as Therapeutic Targets. Drug Discovery Today: Ther. Strategies 2012, 9, e91-e100.

(17) Shishodia, S.; Zhang, D.; El-Sagheer, A. H.; Brown, T.; Claridge, T. D. W.; Schofield, C. J.; Hopkinson, R. J. NMR Analyses on N-Hydroxymethylated Nucleobases - Implications for Formaldehyde Toxicity and Nucleic Acid Demethylases. Org. Biomol. Chem. 2018, 16, 4021-4032.

(18) Fu, Y.; Jia, G.; Pang, X.; Wang, R. N.; Wang, X.; Li, C. J.; Smemo, S.; Dai, Q.; Bailey, K. A.; Nobrega, M. A.; Han, K.-L.; Cui, Q.; He, C. FTO-Mediated Formation of N6-Hydroxymethyladenosine and N6-Formyladenosine in Mammalian RNA. Nat. Commun. 2013, 4, 1798.

(19) Toh, J. D. W.; Crossley, S. W. M.; Bruemmer, K. J.; Ge, E. J.; He, D.; Iovan, D. A.; Chang, C. J. Distinct RNA N-demethylation pathways catalyzed by nonheme iron ALKBH5 and FTO enzymes enable regulation of formaldehyde release rates. Proc. Natl. Acad. Sci. U.S.A. 2020, 117, 25284-25292.

(20) Peng, S.; Xiao, W.; Ju, D.; Sun, B.; Hou, N.; Liu, Q.; Wang, Y.; Zhao, H.; Gao, C.; Zhang, S.; Cao, R.; Li, P.; Huang, H.; Ma, Y.; Wang, Y.; Lai, W.; Ma, Z.; Zhang, W.; Huang, S.; Wang, H.; Zhang, Z.; Zhao, L.; Cai, T.; Zhao, Y.-L.; Wang, F.; Nie, Y.; Zhi, G.; Yang, Y.G.; Zhang, E. E.; Huang, N. Identification of Entacapone as a Chemical Inhibitor of FTO Mediating Metabolic Regulation through FOXO1. Sci. Transl. Med. 2019, 11, No. eaau7116.

(21) Toh, J. D. W.; Sun, L.; Lau, L. Z. M.; Tan, J.; Low, J. J. A.; Tang, C. W. Q.; Cheong, E. J. Y.; Tan, M. J. H.; Chen, Y.; Hong, W.; Gao, Y.-G.; Woon, E. C. Y. A Strategy Based on Nucleotide Specificity Leads to a Subfamily-Selective and Cell-Active Inhibitor of N6Methyladenosine Demethylase FTO. Chem. Sci. 2015, 6, 112-122.

(22) Zheng, G.; Cox, T.; Tribbey, L.; Wang, G. Z.; Iacoban, P.; Booher, M. E.; Gabriel, G. J.; Zhou, L.; Bae, N.; Rowles, J.; He, C.; Olsen, M. J. Synthesis of a FTO Inhibitor with Anticonvulsant Activity. ACS Chem. Neurosci. 2014, 5, 658-665.

(23) Wang, T.; Hong, T.; Huang, Y.; Su, H.; Wu, F.; Chen, Y.; Wei, L.; Huang, W.; Hua, X.; Xia, Y.; Xu, J.; Gan, J.; Yuan, B.; Feng, Y.; Zhang, X.; Yang, C.-G.; Zhou, X. Fluorescein Derivatives as Bifunctional Molecules for the Simultaneous Inhibiting and Labeling of FTO Protein. J. Am. Chem. Soc. 2015, 137, 13736-13739.

(24) Huang, Y.; Yan, J.; Li, Q.; Li, J.; Gong, S.; Zhou, H.; Gan, J.; Jiang, H.; Jia, G.-F.; Luo, C.; Yang, C.-G. Meclofenamic Acid Selectively Inhibits FTO Demethylation of $\mathrm{m}^{6} \mathrm{~A}$ over ALKBH5. Nucleic Acids Res. 2015, 43, 373-384.

(25) Qiao, Y.; Zhou, B.; Zhang, M.; Liu, W.; Han, Z.; Song, C.; Yu, W.; Yang, Q.; Wang, R.; Wang, S.; Shi, S.; Zhao, R.; Chai, J.; Chang, J. A Novel Inhibitor of the Obesity-Related Protein FTO. Biochemistry 2016, 55, 1516-1522.

(26) Aik, W.; Demetriades, M.; Hamdan, M. K. K.; Bagg, E. A. L.; Yeoh, K. K.; Lejeune, C.; Zhang, Z.; McDonough, M. A.; Schofield, C. J. Structural Basis for Inhibition of the Fat Mass and Obesity Associated Protein (FTO). J. Med. Chem. 2013, 56, 3680-3688.

(27) Chen, B.; Ye, F.; Yu, L.; Jia, G.; Huang, X.; Zhang, X.; Peng, S.; Chen, K.; Wang, M.; Gong, S.; Zhang, R.; Yin, J.; Li, H.; Yang, Y.; Liu, H.; Zhang, J.; Zhang, H.; Zhang, A.; Jiang, H.; Luo, C.; Yang, C.-G. 
Development of Cell-Active N6-Methyladenosine RNA Demethylase FTO Inhibitor. J. Am. Chem. Soc. 2012, 134, 17963-17971.

(28) Yan, L.; Colandrea, V. J.; Hale, J. J. Prolyl Hydroxylase DomainContaining Protein Inhibitors as Stabilizers of Hypoxia-Inducible Factor: Small Molecule-Based Therapeutics for Anemia. Expert Opin. Ther. Pat. 2010, 20, 1219-1245.

(29) McMurray, F.; Demetriades, M.; Aik, W.; Merkestein, M.; Kramer, H.; Andrew, D. S.; Scudamore, C. L.; Hough, T. A.; Wells, S.; Ashcroft, F. M.; McDonough, M. A.; Schofield, C. J.; Cox, R. D. Pharmacological Inhibition of FTO. PLoS One 2015, 10, No. e0121829.

(30) Hopkinson, R. J.; Tumber, A.; Yapp, C.; Chowdhury, R.; Aik, W.; Che, K. H.; Li, X. S.; Kristensen, J. B. L.; King, O. N. F.; Chan, M. C.; Yeoh, K. K.; Choi, H.; Walport, L. J.; Thinnes, C. C.; Bush, J. T.; Lejeune, C.; Rydzik, A. M.; Rose, N. R.; Bagg, E. A.; McDonough, M. A.; Krojer, T. J.; Yue, W. W.; Ng, S. S.; Olsen, L.; Brennan, P. E.; Oppermann, U.; Müller, S.; Klose, R. J.; Ratcliffe, P. J.; Schofield, C. J.; Kawamura, A. 5-Carboxy-8-Hydroxyquinoline Is a Broad Spectrum 2-Oxoglutarate Oxygenase Inhibitor Which Causes Iron Translocation. Chem. Sci. 2013, 4, 3110-3117.

(31) Woon, E. C. Y.; Demetriades, M.; Bagg, E. A. L.; Aik, W.; Krylova, S. M.; Ma, J. H. Y.; Chan, M.; Walport, L. J.; Wegman, D. W.; Dack, K. N.; McDonough, M. A.; Krylov, S. N.; Schofield, C. J. Dynamic Combinatorial Mass Spectrometry Leads to Inhibitors of a 2-Oxoglutarate-Dependent Nucleic Acid Demethylase. J. Med. Chem. 2012, 55, 2173-2184.

(32) Woon, E. C. Y.; Tumber, A.; Kawamura, A.; Hillringhaus, L.; Ge, W.; Rose, N. R.; Ma, J. H. Y.; Chan, M. C.; Walport, L. J.; Che, K. H.; Ng, S. S.; Marsden, B. D.; Oppermann, U.; McDonough, M. A.; Schofield, C. J. Linking of 2-Oxoglutarate and Substrate Binding Sites Enables Potent and Highly Selective Inhibition of JmjC Histone Demethylases. Angew. Chem., Int. Ed. 2012, 51, 1631-1634.

(33) Rose, N. R.; Ng, S. S.; Mecinović, J.; Liénard, B. M. R.; Bello, S. H.; Sun, Z.; McDonough, M. A.; Oppermann, U.; Schofield, C. J. Inhibitor Scaffolds for 2-Oxoglutarate-Dependent Histone Lysine Demethylases. J. Med. Chem. 2008, 51, 7053-7056.

(34) Holt-Martyn, J. P.; Chowdhury, R.; Tumber, A.; Yeh, T.-L.; Abboud, M. I.; Lippl, K.; Lohans, C. T.; Langley, G. W.; Figg, W., Jr; McDonough, M. A.; Pugh, C. W.; Ratcliffe, P. J.; Schofield, C. J. Structure-Activity Relationship and Crystallographic Studies on 4Hydroxypyrimidine HIF Prolyl Hydroxylase Domain Inhibitors. ChemMedChem 2020, 15, 270-273.

(35) England, K. S.; Tumber, A.; Krojer, T.; Scozzafava, G.; Ng, S. S.; Daniel, M.; Szykowska, A.; Che, K.; von Delft, F.; Burgess-Brown, N. A.; Kawamura, A.; Schofield, C. J.; Brennan, P. E. Optimisation of a Triazolopyridine Based Histone Demethylase Inhibitor Yields a Potent and Selective KDM2A (FBXL11) Inhibitor. Medchemcomm 2014, 5, 1879-1886.

(36) Wagner, K. W.; Alam, H.; Dhar, S. S.; Giri, U.; Li, N.; Wei, Y.; Giri, D.; Cascone, T.; Kim, J.-H.; Ye, Y.; Multani, A. S.; Chan, C.-H.; Erez, B.; Saigal, B.; Chung, J.; Lin, H.-K.; Wu, X.; Hung, M.-C.; Heymach, J. V.; Lee, M. G. KDM2A Promotes Lung Tumorigenesis by Epigenetically Enhancing ERK1/2 Signaling. J. Clin. Invest. 2013, 123, 5231-5246.

(37) Lu, D.-H.; Yang, J.; Gao, L.-K.; Min, J.; Tang, J.-M.; Hu, M.; Li, Y.; Li, S.-T.; Chen, J.; Hong, L. Lysine Demethylase 2A Promotes the Progression of Ovarian Cancer by Regulating the PI3K Pathway and Reversing Epithelial-mesenchymal Transition. Oncol. Rep. 2019, 41, 917-927.

(38) Leung, I. K. H.; Demetriades, M.; Hardy, A. P.; Lejeune, C.; Smart, T. J.; Szöllössi, A.; Kawamura, A.; Schofield, C. J.; Claridge, T. D. W. Reporter Ligand NMR Screening Method for 2-Oxoglutarate Oxygenase Inhibitors. J. Med. Chem. 2013, 56, 547-555.

(39) Chowdhury, R.; Candela-Lena, J. I.; Chan, M. C.; Greenald, D. J.; Yeoh, K. K.; Tian, Y.-M.; McDonough, M. A.; Tumber, A.; Rose, N. R.; Conejo-Garcia, A.; Demetriades, M.; Mathavan, S.; Kawamura, A.; Lee, M. K.; van Eeden, F.; Pugh, C. W.; Ratcliffe, P. J.; Schofield, C. J. Selective Small Molecule Probes for the Hypoxia Inducible
Factor (HIF) Prolyl Hydroxylases. ACS Chem. Biol. 2013, 8, 14881496.

(40) Hillringhaus, L.; Yue, W. W.; Rose, N. R.; Ng, S. S.; Gileadi, C.; Loenarz, C.; Bello, S. H.; Bray, J. E.; Schofield, C. J.; Oppermann, U. Structural and Evolutionary Basis for the Dual Substrate Selectivity of Human KDM4 Histone Demethylase Family. J. Biol. Chem. 2011, 286, 41616-41625.

(41) Han, Z.; Niu, T.; Chang, J.; Lei, X.; Zhao, M.; Wang, Q.; Cheng, W.; Wang, J.; Feng, Y.; Chai, J. Crystal Structure of the FTO Protein Reveals Basis for Its Substrate Specificity. Nature 2010, 464, $1205-1209$.

(42) Zhang, X.; Wei, L.-H.; Wang, Y.; Xiao, Y.; Liu, J.; Zhang, W.; Yan, N.; Amu, G.; Tang, X.; Zhang, L.; Jia, G. Structural Insights into FTO's Catalytic Mechanism for the Demethylation of Multiple RNA Substrates. Proc. Natl. Acad. Sci. U.S.A. 2019, 116, 2919-2924.

(43) Chowdhury, R.; McDonough, M. A.; Mecinović, J.; Loenarz, C.; Flashman, E.; Hewitson, K. S.; Domene, C.; Schofield, C. J. Structural Basis for Binding of Hypoxia-Inducible Factor to the Oxygen-Sensing Prolyl Hydroxylases. Structure 2009, 17, 981-989.

(44) Chowdhury, R.; Leung, I. K. H.; Tian, Y.-M.; Abboud, M. I.; Ge, W.; Domene, C.; Cantrelle, F.-X.; Landrieu, I.; Hardy, A. P.; Pugh, C. W.; Ratcliffe, P. J.; Claridge, T. D. W.; Schofield, C. J. Structural Basis for Oxygen Degradation Domain Selectivity of the HIF Prolyl Hydroxylases. Nat. Commun. 2016, 7, 12673.

(45) Yeh, T.-L.; Leissing, T. M.; Abboud, M. I.; Thinnes, C. C.; Atasoylu, O.; Holt-Martyn, J. P.; Zhang, D.; Tumber, A.; Lippl, K.; Lohans, C. T.; Leung, I. K. H.; Morcrette, H.; Clifton, I. J.; Claridge, T. D. W.; Kawamura, A.; Flashman, E.; Lu, X.; Ratcliffe, P. J.; Chowdhury, R.; Pugh, C. W.; Schofield, C. J. Molecular and Cellular Mechanisms of HIF Prolyl Hydroxylase Inhibitors in Clinical Trials. Chem. Sci. 2017, 8, 7651-7668.

(46) Figg, W. D., Jr; McDonough, M. A.; Chowdhury, R; Nakashima, Y.; Zhang, Z.; Holt-Martyn, J. P.; Krajnc, A.; Schofield, C. J. Structural Basis of Prolyl Hydroxylase Domain Inhibition by Molidustat. ChemMedChem 2021, 16, 2082.

(47) Aguilar, J. A.; Nilsson, M.; Bodenhausen, G.; Morris, G. A. Spin Echo NMR Spectra without J Modulation. Chem. Commun. 2012, 48, $811-813$.

(48) Otwinowski, Z.; Minor, W. [20] Processing of X-ray diffraction data collected in oscillation mode. Macromolecular Crystallography Part A; Academic Press, 1997; Vol. 276, pp 307-326.

(49) Winter, G. Xia2: An Expert System for Macromolecular Crystallography Data Reduction. J. Appl. Crystallogr. 2010, 43, 186190.

(50) McCoy, A. J.; Grosse-Kunstleve, R. W.; Adams, P. D.; Winn, M. D.; Storoni, L. C.; Read, R. J. Phaser Crystallographic Software. J. Appl. Crystallogr. 2007, 40, 658-674.

(51) Liebschner, D.; Afonine, P. V.; Baker, M. L.; Bunkóczi, G.; Chen, V. B.; Croll, T. I.; Hintze, B.; Hung, L.-W.; Jain, S.; McCoy, A. J.; Moriarty, N. W.; Oeffner, R. D.; Poon, B. K.; Prisant, M. G.; Read, R. J.; Richardson, J. S.; Richardson, D. C.; Sammito, M. D.; Sobolev, O. V.; Stockwell, D. H.; Terwilliger, T. C.; Urzhumtsev, A. G.; Videau, L. L.; Williams, C. J.; Adams, P. D. Macromolecular Structure Determination Using X-Rays, Neutrons and Electrons: Recent Developments in Phenix. Acta Crystallogr., Sect. D: Struct. Biol. 2019, 75, 861-877.

(52) Shishodia, S.; Schofield, C. J. Improved Synthesis of Phosphoramidite-Protected N6-Methyladenosine via BOP-Mediated SNAr Reaction. Molecules 2021, 26, 147.

(53) Emsley, P.; Lohkamp, B.; Scott, W. G.; Cowtan, K. Features and development of Coot. Acta Crystallogr., Sect. D: Biol. Crystallogr. 2010, 66, 486-501. 


\section{University Library}

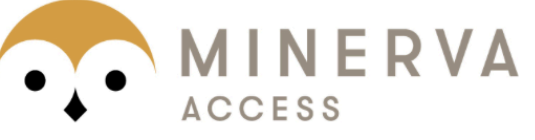

A gateway to Melbourne's research publications

Minerva Access is the Institutional Repository of The University of Melbourne

Author/s:

Shishodia, S;Demetriades, M;Zhang, D;Tam, NY;Maheswaran, P;Clunie-O'Connor, C;Tumber, A;Leung, IKH;Ng, YM;Leissing, TM;El-Sagheer, AH;Salah, E;Brown, T;Aik, WS;McDonough, MA;Schofield, CJ

Title:

Structure-Based Design of Selective Fat Mass and Obesity Associated Protein (FTO)

Inhibitors

Date:

2021-11-25

Citation:

Shishodia, S., Demetriades, M., Zhang, D., Tam, N. Y., Maheswaran, P., Clunie-O'Connor, C., Tumber, A., Leung, I. K. H., Ng, Y. M., Leissing, T. M., El-Sagheer, A. H., Salah, E., Brown, T., Aik, W. S., McDonough, M. A. \& Schofield, C. J. (2021). Structure-Based Design of Selective Fat Mass and Obesity Associated Protein (FTO) Inhibitors. JOURNAL OF MEDICINAL CHEMISTRY, 64 (22), pp.16609-16625. https://doi.org/10.1021/acs.jmedchem.1c01204.

Persistent Link:

http://hdl.handle.net/11343/296474

License:

CC BY 